$15^{2}$
11128173

INFORMAL REPORT

$\therefore$

Performance of (U, Zr)C-Graphite (Composite) and of $(U, Z r) C$ (Carbide) Fuel Elements in the Nuclear Furnace 1 Test Reactor 
This report was prepared as an account of work sponsored by the United States Government. Neither the United States nor the United States Atomic Energy Commission, nor any of their employees, nor any of their contractors, subcontractors, or their employees, makes any warranty, express or implied, or assumes any legal liability or responsibility for the accuracy. com. pleteness or usefulness of any information, apparatus, product or process dis. closed, or represents that its use would not infringe privately owned rights.

In the interest of prompt distribution, this LAMS report was not edited by the Technical Infurmation staff.

Printed in the United States of America. Available from National Technical Information Service

U. S. Department of Commerce

5285 Port Royal Road

Springfield, Virginia 22151

Price: Printed Copy 55.45; Microliche $\mathbf{5 0 . 9 5}$ 


\section{LA-5398-MS \\ Informal Report \\ UC.33}

ISSUED: September 1973

\title{
Performance of (U,Zr)C-Graphite (Composite) and of $(U, Z r) C$ (Carbide) Fuel Elements in the Nuclear Furnace 1 Test Reactor
}

\author{
by
}

Luther L. Lyon

This work was done for the Space Nuclear Systems Office, a joint olfice of the U.S. Atomic Energy Commission and the National Aeronautics and Space Administration.

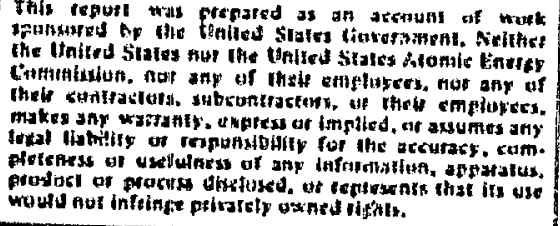




\section{CONTENTS}

Abstract $\quad 1$

I. Introduction 1

II. (U,zr)C-Graphite (Composite) Fuel Elements 2

A. Fabrication 2

B. Thermal-stress Resistance 2

C. Properties of Composite Elements 3

III. Reactor Performance of Composite Elements S

IV. $(0,2 x) c(C a r b i d e)$ siel Elements 11

v. Reactor Performance of Carbide Elements 12

VI. Conclusions 14

A. Composite Elements 14

8. Carbide Elements 15

C. Reactor Performance of Composite vs Graphite Elements 16

$\begin{array}{ll}\text { VII. Appendixes } & 17\end{array}$

Appendix A - History of LASL Developnent of Carbide." Graphite Composite Structural Materlals; (U, 2r) C-Graphite (Composite) Fuel Elements; and $(U, z x) C$ Fuel Elements

Appendix 9 - A Comprehenaive Study of Composite Fuel Element Hatrices: The NF-1 Experiment

Appendix $C$ - Properties of $(U, z r)$-Graphite (Composite) Fuel Elements

Appendix 0 a stability of $(0,2 r) C-G r a p h i t e$ Fuel Elenents 
PERFORMANCE OF (U,2r) C-GRAPHITE (COMPOSITE)

AND OF $(U, Z I) C$ (CARBIDE) FUEL ELEMENTS IN THE

NUCLEAR FURNACE 1 TEST REACTOR

by

Luther I. Lyon

\section{ABSTRACT}

The properties of and reactor test results for two types of nuclear-propulsion-reactor fuel elements containing uraniumIrconium carbide, (U,zr) , are reported, composite fuel elements containing graphite and $\eta 35$ vols carbide, along with Fuel elements consisting only of carbide, were tested In Los Alamos Sclentific Laboratory's Nuclear Purnace 1 reactor for 109 min at peak power densities of $\sim 4500 \mathrm{~mW} / \mathrm{m}^{3}$ and temperatures up $t$, $2500 \mathrm{R}$. Fission-fragment damage to the graphite phase of the composite fuei elements increased the room-temperature thermal resistivity of the matrix nirefold, resulting in unexpected high masa losses of carbon. The carblde elements dereloped both longitudinal and transverse fractures but did not fragment into amalisize particles.

\section{INTRODUCRION}

The ugefulneas of new types of exper1mental nuclear-rocket-reactor filel elenents for the Rover program was evalunted in a specially devised small test reactor, Nuclear Furnace 1 . Six separate tests of the reactor were conducted during the sumer of 1972 at the Nuclear Rocket Development station at Jackass Plats, Nevada. 1 Thls report presenta reactor performance data on two types of experimental fuel elements containing uraniun-zirconium carbide, (U,2r) $C$, which were tested for $109 \mathrm{~min}$ at watrix temperaturea of up to $2500 \mathrm{~K}$ and peak power densities of 4500 to $5000 \mathrm{MH} / \mathrm{m}^{3}$.

\footnotetext{
The Rover progzan was adminietered by the space Nuclear systems office, a joint office of the U.S. Atomic Energy Commission and the Natlonal heronautics and space ndminlstration. The tos Nlamos scientiflc Laboratcry, arime contractor for the hover progran from 1956 to 1973 , developed and tested the X1wi, Phoebus, and Pewee sertes of space nuclear propulsion test reactors. The progran was terminated on Januaxy 5, 1973 .
}

The fuel elenents used from 1964 to 2969 in six nuclear propulsion test reactors of the KLwi, Phuebus, and Pewee design had a graphite matrix containing pyrocarbon-coated UC2 spheres of 150 um maximun diameter. Multiple coolant channele, coited with MbC or $2 r c$ to protect the carbon in the matrix from reaction with the hydrogen propellant, formed flow pasaages through the 1.32-m-1ong elaments. Succenaful reactor testa of up to one hour duration with maximum matrix temperatures of 2400 to $2600 \mathrm{~K}$ were conducted with these elements. However, mass losses of carbon from the elements at thr end of one hour of teating were high enough to adversely affect the neutronic characteristics of the reactor core. The development of new fuel elements, which would be highly resigtant to hydrogen attack and could be used at high operating temperatures, was therefore initiated. Two approaches were taken: (1) retain the fuel-element geometry but change the matrix to a composite of carbide and graphite with up to 35 voll of the 
matrix consisting of a solid-solution $(U, \mathrm{Zr}) \mathrm{C}$ carbide, and (2) produce a new allcarbide fuel element frosn $(U, z r) C$ substoichiometric in carbor. The composite $=1 \mathrm{le}-$ ment would still require protective zrC coatings in the flow passages, but, because of a continuous network of carbide throughout the matrix, would better be able to resist massive erosion conditions than the all-graphite type of fuel element. The carbide element, of course, would suffer very small carbon losses because it could only lose chemically combined carbon. The properties of and the performance in the Nuclear Turnace 1 (NF-1) reactor of these elements are described. -- (The NF-l reactor was a heterogeneous water-moderatei beryllium-reflerted reactor containing 49 cells in which fuel elements could be tested. 1 Neutronic control was provided by $s i x$ rotatable drums in the reflector. During operation, water flowed in a two-pass systelt between the cell tubes while hydrogen gas flowed through the fuel elements. Thermocouples measured the exit-gas temperature from each cell. The hot hydrogen gas exhausted from the fuel elemenis was cooled by infecting water directly into the gas stream. The resulting mixture of steam and hydrogen was ducted to an effluent cleanup system. After water injection, the effluent consisted of a mixture of steam, hydrogen, and radioactive contaminants at $\sim 600 \mathrm{~K}$. The effluent was filtered, cooled and watercondensed, dried, passed through a cryogenically cooled charcoal trap, and finally discharged into the atmosphere.)

II. (U, Zr)C-GRAPHITE (COMPOSTTE) FUEL ELEMENTS

\section{A. Pabrication}

The composite elements were extruded Exom a mix consisting of graphite flour. carbon black, $2 \mathrm{rC}_{1} \mathrm{vO}_{2}$, and liquid thermosetting binder. ${ }^{2}$ solid-solution (U,zr)C was formed in the elements during final heat ireatment. A protective zrC coating was applied to the flow passages and exterior surfaces by a chemical vapor-deposition process. The composite fuel elements, Fig. 1. were fabricated to a constant volume content of totai carbide, regaraless of the amount of uranium in each element. By keeping the volume content of carbide constart, a uniform coefficient of thermal expansion was maintained over the uranium loading range of interest in nuclear propulsion reactors, i.e., 200 to $650 \mathrm{~kg} / \mathrm{m}^{3}$. Typical chemical-analysis data ${ }^{*}$ for composite elements of 35 voli carbide content are given in Table $I$. One objective was the production of elements of acceptable thermalstress resistance whose arc coatings would have a minimum of physical defects affecting mass loss rates.

\section{B. Thermal-Stress Resistance}

The thermal-stress resistance was improved by increasing the thermal conductivity through a carefully controlled heattraatment process at temperatures at which 10 to 208 of the carbide was Iiquid. During this heat-treatment the carbide particles coalesced into a strong interconnected carbide network. The three photomicrographs in Fig. 2 illustrate some of the matrix microstructures that were obtained by varying the heat-treatment temperatures. These temperatures are shown on the pseudobinary phase diagram of the $U-2 r \cdots C$ system, Fig. 3 . Matrices with Microstructure 1, representative of a heat-treatment temperature below the solidus line, had a thermal conw ductivity of $\sim 50 \mathrm{w} / \mathrm{m} \cdot \mathrm{K}$ at $300 \mathrm{~K}$, with individual carbide particles dispersed around the unmodified particles of graohite filler flour. Matrices with Microstructure 2, representative of heat-treatment conditions at which 10 to 20 s of the carbide phase was

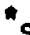
SI units are used in this report. Because in this system no multipliers are used in the derominator, uranium loading is expressed as $\mathrm{kg} / \mathrm{m}^{3}$ instead of $\mathrm{mg} / \mathrm{cm}^{3}$, and density as $\mathrm{Mg} / \mathrm{m}^{3}$ instead of $\mathrm{g} / \mathrm{cm}^{3}$. Pressure is expressed in pascals (Pa):--multiply pei by 0.006894 to obtasin MPa, e.g. $1000 \mathrm{psi}=27 \mathrm{MPa}$. 
Iiquid, had a thermal conductivity of $\sim 80$ $\mathrm{w} / \mathrm{m} \cdot \mathrm{K}$, the carbide had formed a continuousnetwork type of structure, and the graphite particies had undergone modification. Matrices with Micrcstructure 3, representative of heat-treatment conditions where most of the carbice chase was liquid, had a thermal conductivity of over $140 \mathrm{~h} / \mathrm{m} \cdot \mathrm{K}$ at $300 \mathrm{k}$, the carbide had largely coalesced, and most of the graphite was in a highly ordered proeutectic form. The increase in thermal conductivity is attributed to the ordering of the crystallites in the graphite flour particles and in the binder carbon alded by the presence of liquid carbide. Matrices with Microstructure $z$ were preferred because their thermal conductivities were relatively high and their mechanical properties were satisfactory; matrices with Microstructure 3 hid about one-tenth the flexural strength of those with Microstructure 2. Figure 4 is a scanning-electron photomicrograph of the $(U, 2 r) C$ network in a composite element. All the graphite phase had been removed by leaching with hydrogen at $\sim 2000 \mathrm{k}$. Note the continuous threedimensional structure of the carbide. Removal of the graphite did not alter the dimensions of the element. However, the roomtemperature compressive strength of the leached element was $\sim 10 \mathrm{MPa}$ as compared to $2110 \mathrm{MPa}$ for the unleached element.

\section{c. yroperties of Composite Elements}

The factors that controlled the formation of defect-free 2 rC protective coatings were: (1) the temperature of $\mathrm{zrc}$ deposition, (2) the thlckness of the zrc. coating, and (3) the therma? expansion properties of both the $\mathrm{zrc}$ and the fuelelement matrix. The coeficient of thermal expansion (CTE) of vapor-deposited $2 \mathrm{rC}$ was $27.7 \mathrm{um} / \mathrm{m} \cdot \mathrm{g}$ for the 293- to 2300-k temperature range. The matrix longitudinal CTE had to be $\$ 6.6 \mathrm{\mu m} / \mathrm{m}^{2} \mathrm{X}$ or the very adherent $2 r c$ coating would form microrracks upon csoling from the deposition temperature (n $1500 \mathrm{k}$ ). In a series of experimente
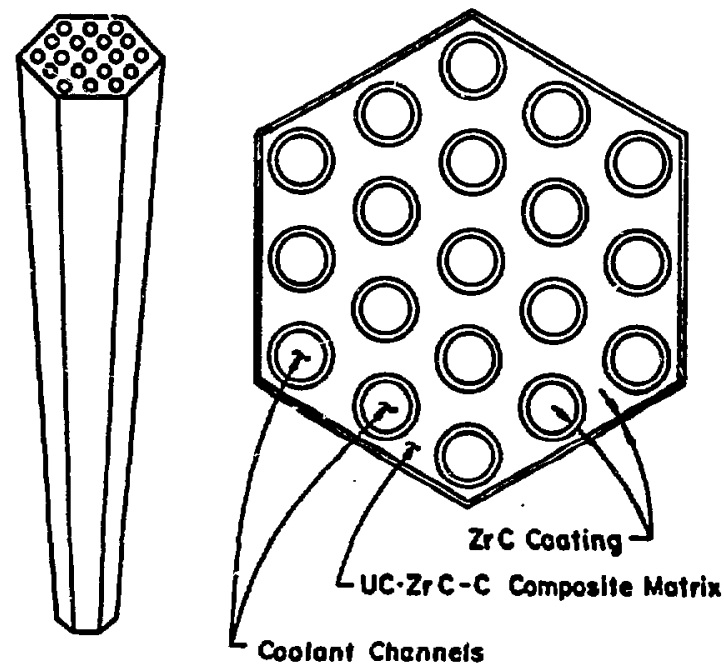

Fig. 1. Full-length and cross-section views of composite fuel element. Length. $1.32 \mathrm{~m}$; aczoss-fiats, $19 \mathrm{~mm}$; coolant-channel diameter, $2.3 \mathrm{~mm}$ mass, $\imath 1.1 \mathrm{~kg} ;$ and volume, $284 \times 10^{-6} \mathrm{~m}$ ?

TABLE I

CHEMICAL ANALYSIS DATA FOR COMPOSITE FUEL ELEMENT KATRICES

\begin{tabular}{lccc}
\hline & \multicolumn{3}{c}{$\begin{array}{c}\text { Uranium Loading, } \\
\mathrm{kg} / \mathrm{m}^{3}\end{array}$} \\
\cline { 2 - 4 } Paraneter & 180 & 399 & 598 \\
U, wts & 5.2 & 11.1 & 16.4 \\
$\mathrm{Zr}$, wts & 56.0 & 52.5 & 49.6 \\
C. wts (total) & 38.8 & 36.0 & 33.6 \\
Density, Mg/m & 3.49 & 3.61 & 3.64 \\
Carbide content, vols & 34.9 & 35.5 & 35.6 \\
u. at. on a metal basis & 3.5 & 7.6 & 11.4
\end{tabular}

with 50- to 150-um-thick zrc coatings on matrices of varying CTE the coatings formed cracks at strains $\$ 1000 \mu \mathrm{m} / \mathrm{m}$. To minimize this mismatch in CTE between the matrix and the coating, the thermal expansion of the matrices was increased by using high-CTE graphite filler flours and by increasing the volune content of the carbide phase. However, matrices of $\$ 40$ vols carbide had poor thermal-stress resistance, and, if the carbide content was lower than 30 vols. their maximum uranium loading had to be deczessed to avoid conditions at which $u c_{a}$ 


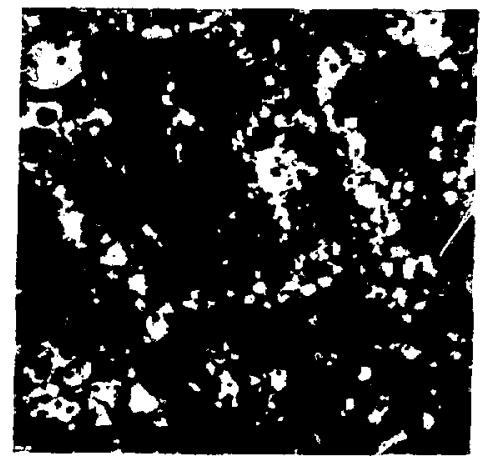

(1)

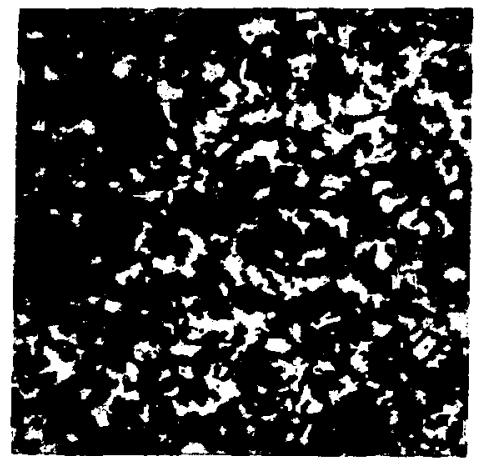

(2)

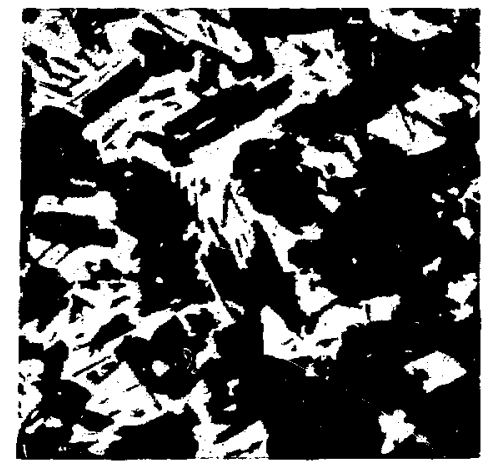

(3)

$\rightarrow \mid 1 \leftarrow 10 \mu \mathrm{m}$

Fig. 2. Photomicrographs of $(\mathrm{U}, \mathrm{2r}) \mathrm{C}$-graphite matrices containing 35 vols carbide and $\sim 400 \mathrm{~kg} / \mathrm{m}^{3}$ of 938 -enriched uranium. The white areas are carbide, the gray areas are graphite, and the black areas are void. Heat treatment at (1) ح $2800 \mathrm{~K}$; (2) ح $3050 \mathrm{~K}$; (3) $3120 \mathrm{~K}$.

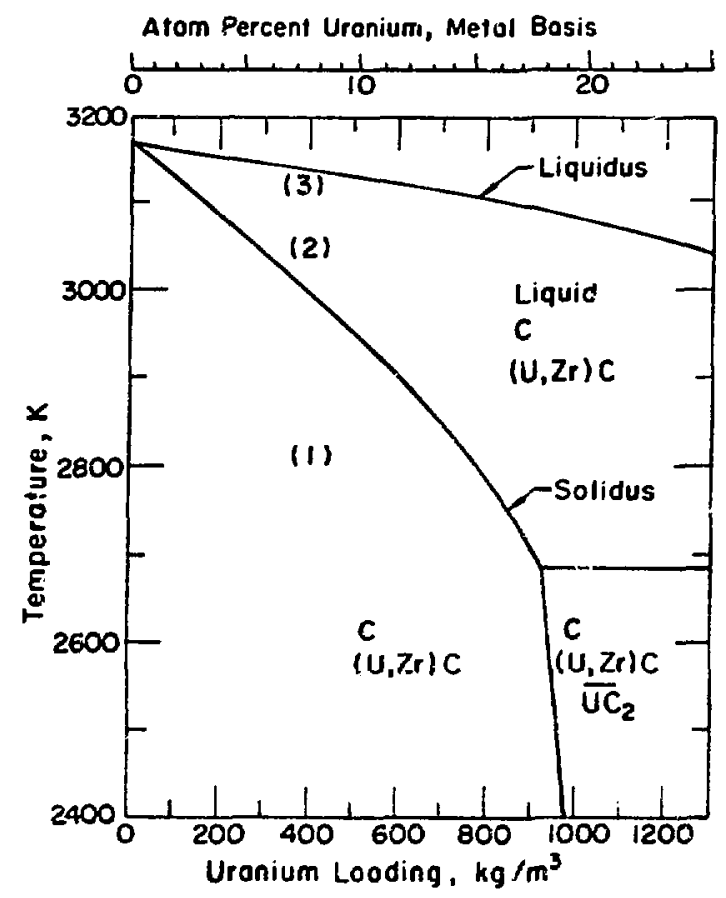

vig. 3. Portion of pseudobinary phase diagram for U-2r-C system for composite elements containing 35 vol carbide. (1), (2), and (3) refer to heat-treatment temperatures in Fig. 2.

would form (see lower right-hand corner of phase diagram, Fig. 3).

Some properties of $(U, 2 r) C$-graphite (composite) fuel elements are given in Table II. The thermal-stress resistance was evaluated by measuring the electrical power

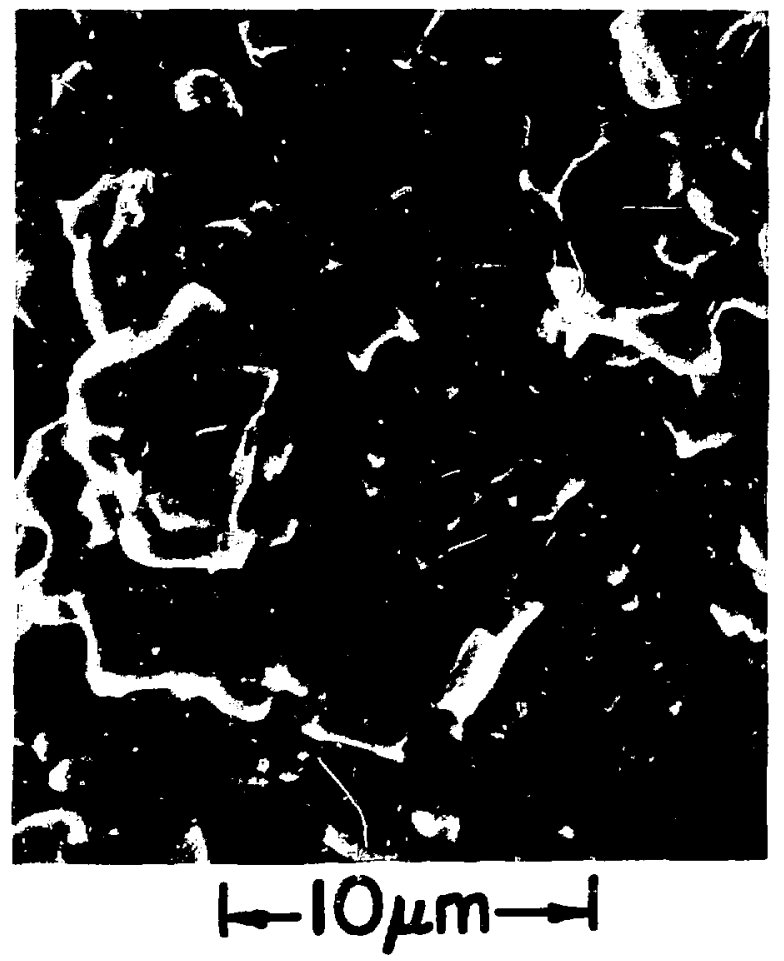

Fig, 4. Scanning-electron photomicrograph of the $(U, 2 r) C$ network structure in a composite element.

density required to fracture a fuel-element specimen. The test conditions of pressure and hydrogen flow rate simulated those encountered in a nuclear propulsion reactor. 
TABLE II

GENERAL CHARACTERISTICS OF (U, Zr) C-GRAPHITE (COMPOSITE) FUEL ELENENTS

\section{Parameter}

Carbide content, vols

Useful u-loading range, $\mathrm{kg} / \mathrm{m}^{3}$

Thermal conductivity $(300 \mathrm{~K}), \mathrm{W} / \mathrm{m} \cdot \mathrm{K}$

Coeff. of thermal expansion $(293$ to $2300 \mathrm{~K}), \mu \mathrm{m} / \mathrm{m} \cdot \mathrm{K}$

Flexural strength (300 K) MPa

Compressive strength $(300 \mathrm{~K})$, MPa

Strain to fracture $(300 \mathrm{~K})$, $\mu \mathrm{m} / \mathrm{m}$

srress at fracture $(300 \mathrm{~K})$, MPa

Elastic modulus (300 K), GPa

Compressive deformation at $2800 \mathrm{~K}(3.5 \mathrm{MPa}$ for $1 \mathrm{~h}), 8$

Thermal stress resistance at $\sim 1700 \mathrm{~K}$ (power density at fracture). $\mathrm{MW} / \mathrm{m}^{3}$

Forty-seven composite fuel elements were used in the NF-1 reactor. These elements were dividea into three broad experiments: (i) a carbide-content experiment of 30 vs 35 voli, (2) a matrix CTE experiment of 6.1 vs 6.7 $\mathrm{m} / \mathrm{m} \cdot \mathrm{K}$, and (3) a matrix thermal-stress-resistance experiment with fracture power densities of 4700 to 6200 $M W / \mathrm{m}^{3}$. Table III summarizes the range of properties of these elements in the reactor. The CTE experiment was, in reality, a $\mathrm{ZrC}$ coating-crack experiment. The coatings on matrices with a CTE of $6.1 \mu \mathrm{m} / \mathrm{m} \cdot \mathrm{K}$ formed ح 600 circumferential cracks/meter of coolant-channel length on cooldown from the temperature (1500 K) at which the coatings were applied; but the coatings on matrices with a CTE $\$ 6.5 \mu \mathrm{m} / \mathrm{m} \cdot \mathrm{K}$ were essentially crack-free as fabricated and

*Five of the 30-vols composite elements were fabricated by the Westinghouse Astronuclear Laboratory (WANL) as part of the Nuclear Engine for Rocket Vehicle Application Program (NERVA).
TABLE III

RANGE OF MATRIX PROPERTIES OF COMPOSITE ELEMENTS IN THE NF-1 REACTOR

\begin{tabular}{|c|c|c|c|}
\hline $\begin{array}{l}\text { Carbide } \\
\text { Content, } \\
\text { vols } \\
\end{array}$ & $\begin{array}{l}\text { Thermal }^{a} \\
\text { Expansion, } \\
\mu \mathrm{m} / \mathrm{m} \cdot \mathrm{K}\end{array}$ & $\begin{array}{l}\text { Thermal } \\
\text { Conductivity, } \\
\mathrm{W} / \mathrm{m} \cdot \mathrm{K}\end{array}$ & $\begin{array}{c}\text { Fracture } \\
\text { Power Density } \\
\mathrm{MW} / \mathrm{m}^{3} \\
\end{array}$ \\
\hline 35 & 6.7 & 75 & 4700 \\
\hline 35 & 6.7 & $7 \dot{q}$ & 4900 \\
\hline 35 & 6.6 & 71 & 5000 \\
\hline 35 & 6.6 & 84 & 5200 \\
\hline 35 & 6.8 & 80 & 5400 \\
\hline 35 & 6.8 & 87 & 6100 \\
\hline 30 & 6.5 & 83 & 5500 \\
\hline 30 & 6.5 & 77 & 5800 \\
\hline 30 & 6.6 & 75 & 6200 \\
\hline 30 & 6.1 & $40-50$ & 4700 to 5500 \\
\hline
\end{tabular}

installed in the reactor. Based on the results obtained from component tests, very low carbon mass losses were predicted for those elements in the NF-1 reactor with crack-free $\mathrm{ZrC}$ coatings.

The details of a standard $\mathrm{NF}-1$ reactor cell in which a composite element was housed is shown in Fig. 5. The NF-1 reactor fullpower conditions that affected the composite fuel elements are listed in Table IV.

\section{REACTOR PERFORMANCE OF} COMPOSITE ELEMENTS

Postmortem examinations comprised rather sophisticated nondestructive and destructive examinations as a function of fuel-element length. A position along the 1.32-m-1ong element was designated a station, measured in millimeters from the cold end of the element where the hydrogen propellant entered.

The mass losses ranged from 8 to over $50 \mathrm{~g} /$ element. The 24 elements with a CTE of $6.1 \mu \mathrm{m} / \mathrm{m} \cdot \mathrm{K}$ had an average loss of 37.6 g/element as compared to $13.7 \mathrm{~g}$ for the 23 


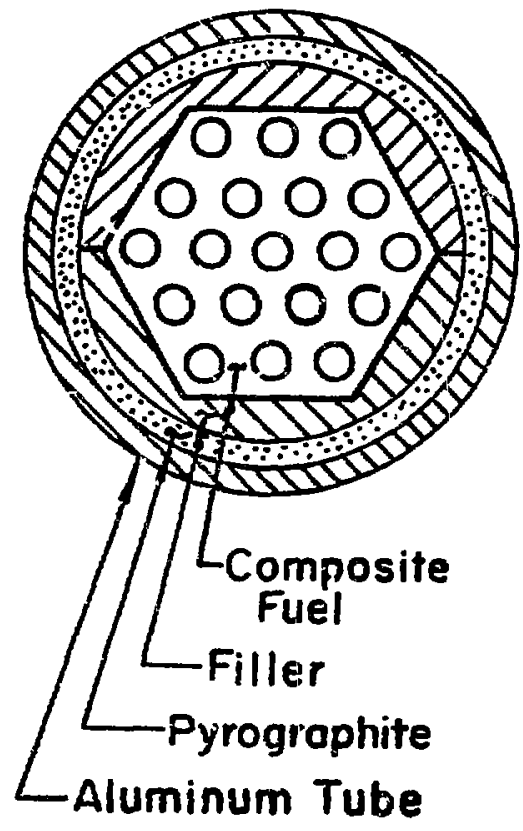

Fig. 5. NF-1 reactor cell containing (U, $2 r)$ C-graphite (composite) fuel element. The filler material was an extruded composite of 30-voli $\mathrm{zrC}$ and the remainder graphite.

elements with a $\operatorname{CTE}>6.5 \mu \mathrm{m} / \mathrm{m} \cdot \mathrm{K}$. Twothirds of the mass loss ${ }^{\star}$ ciccurred in the midrange region, between Stations 300 and 600 (Figs. 6 and 7). Large losses in the midrange region were unexpected, and very little loss had been predicted in this region for the high-CTE elements. However, the mass loss rates for the hot-end region, Station 1000 to 1300 , were within the range of loss rates determined by laboratory component tests (Fig. 8).

Mass losses associated with matrix cracks were observed in several composite elemeits. The small peak in the mass-loss curve at Station 1300, Fig. 6, and the peaks from Station 800 to 1300 in Fig. 7 were the result of matrix crasking and of associated cracks in the $2 \mathrm{IC}$ protective coating. Matrix cracking was readily detected by high-resolution eddy current

\footnotetext{
"Mass-per-unit length evaluation (MULE) was performed nondestructively by using gamma-ray absorptometry. 3
}

TABLE IV

\section{NF-1 REACTOR FULI-POWER CONDITIONS}

Parameter

Reactor thermal power, MW Power/composite element, MW Hydrogen flow/element, $\mathrm{kg} / \mathrm{s}$ Hydrogen-inlet pressure, MPa outlet pressure, MPa inlet temp. , $K$

Maximum matrix temp., $K$ Peak power density, $M W / \mathrm{m}^{3}$ Run time at full power, min outlet temp., $K$

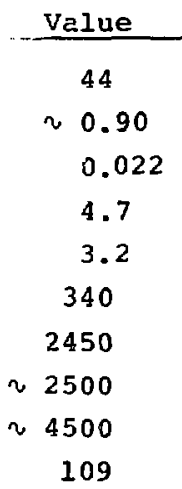

examination of each coolant channel. Most matrix cracks were found at the higher stations and not too many were observed in the vicinity of Station 700, the peak of power generation. The matrix cracks at the higher stations were believed to have occurred during two automatic emergency shutjowns from full power when the control temperatures during the first 5 sec of the shutdown changed at an average rate of $\sim 300 \mathrm{k} / \mathrm{sec}$.

The high-CTE elements were examined for type and number of coating cracks as a function of station. Surprisingly, numerous coating cracks occurred at the cold end of the element (Figs. 9 and 10). These coating cracks were the cause of the unexpected mass loss in the midrange region, i.e., the loss was due to the transport of hydrogen and of its products of reaction with the matrix (methane and acetylene) in and out of open coating cracks. The peak in the mass-loss curve was caused by the increased reaction rate of hydrogen with carbon at temperatures above $1000 \mathrm{~K}$ (Station 250); however, the coating cracks were closing as the temperature increased and they were essentially closed at $1600 \mathrm{~K}$ (Station 500)--a temperature slightly above that used in depositing the $\mathrm{ZrC}$ (see Fig. 11 for matrix temperature vs station). The coating cracks could have been caused by the large temperature gradient 


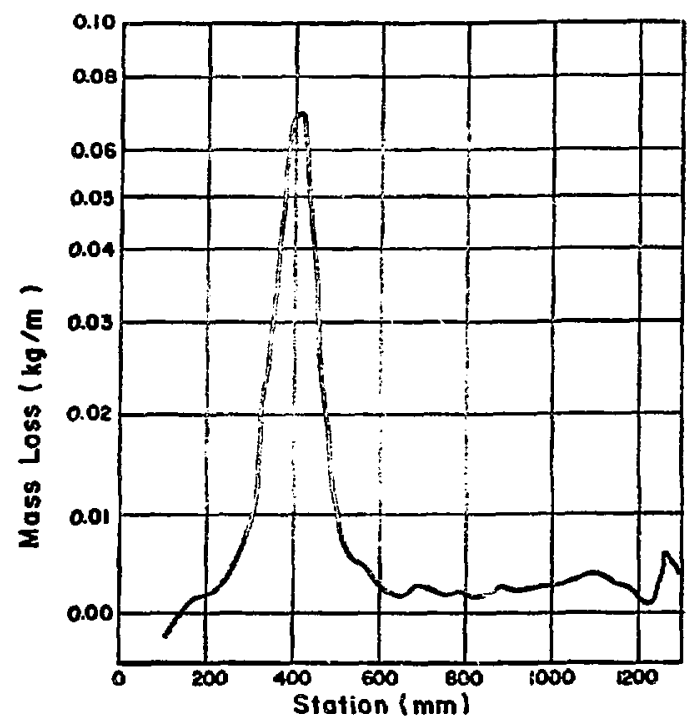

Fig. 6. Mass loss vs length for a $(\mathrm{U}, \mathrm{zr}) \mathrm{C}-$ graphite element with a thermal expansion > $6.5 \mu \mathrm{m} / \mathrm{m} \cdot \mathrm{K}$.

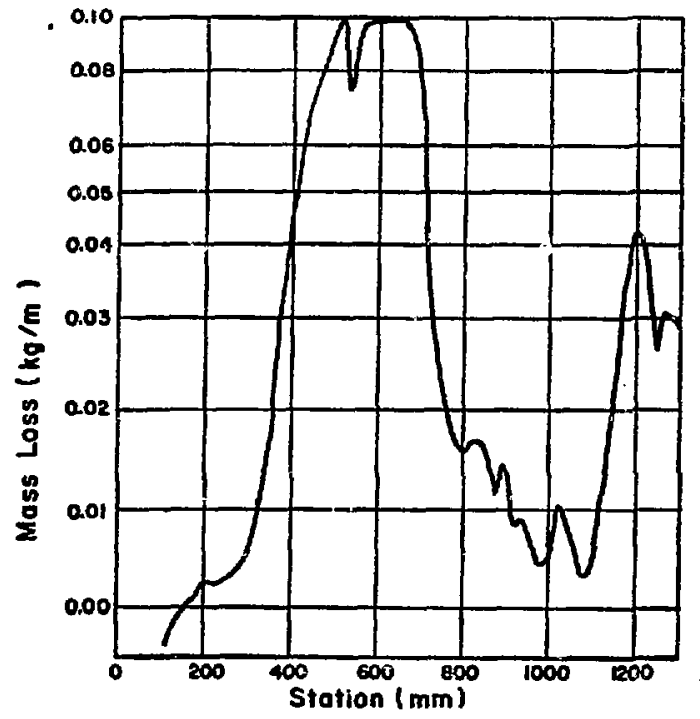

Fig. 7. Mass loss vs length for a $(U, 2 r) C-$ graphita element with a thermal expansion of $6.1 \mathrm{\mu m} / \mathrm{m} \cdot \mathrm{K}$.

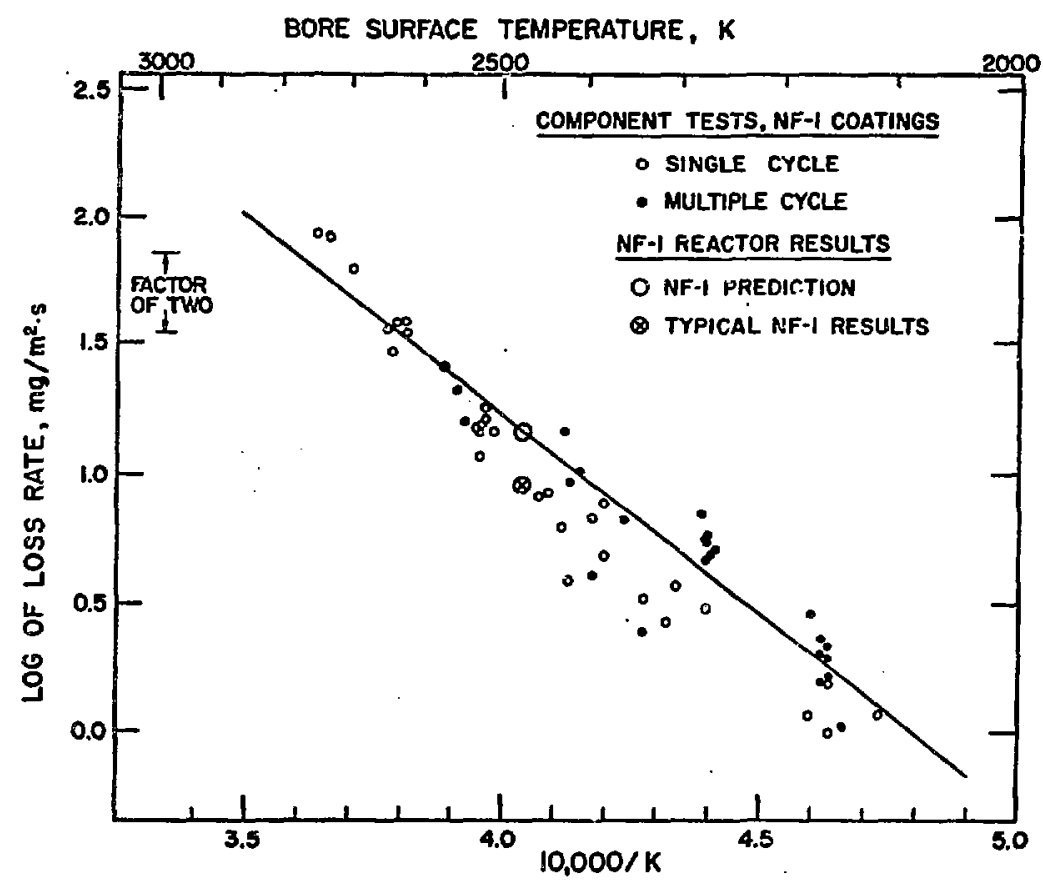

Fig. 8. Component and $\mathrm{NF}-1$ reactor test results for hot-end mass-loss rates of composite elements. Loss rates per second are given in milligrams of loss per square meter of coolant channel surface area. 


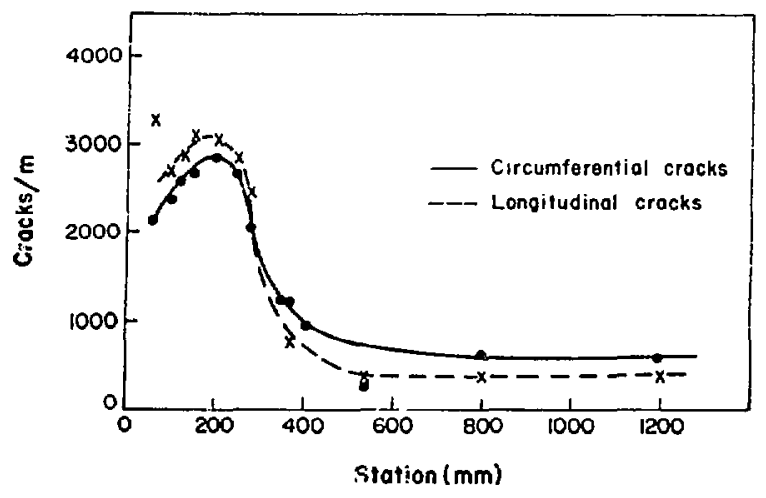

Fig. 9. Number of cracks in ZrC coolantchannel coating as a function of length for a NF-1 composite Iuel element.

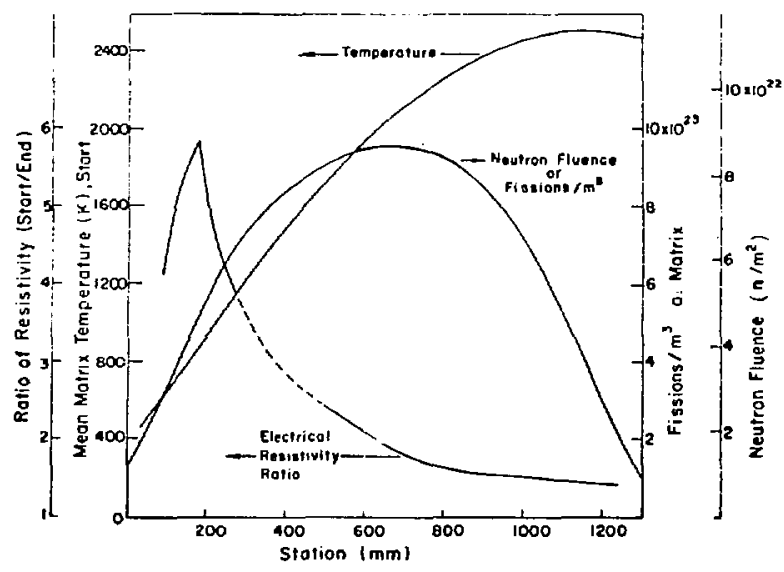

Fig. 11. Fuel-element environment vs length: temperature, fissions, and fastneutron fluence $(>0.18 \mathrm{MeV})$. Also plotted is the change in roomtemperature electrical-resistivity ratio for a composite fuel element, start to end, of the NF-1 reactor run.

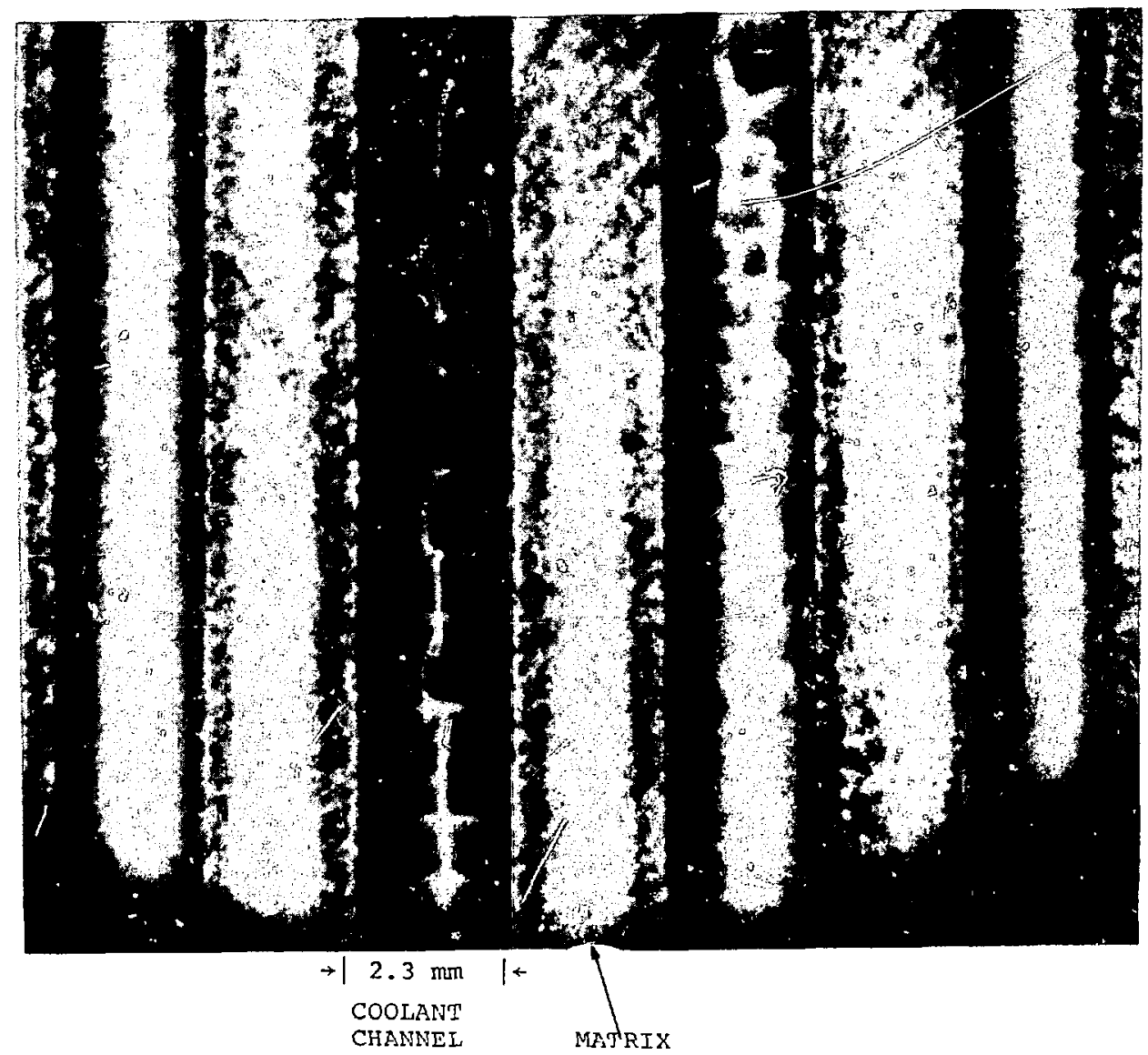

Fig. 10. Split composite fuel element from the NF-1 reactor showing cracks in the $\mathrm{ZrC}$ coolant-channel coating. 
generated during the two emergency shutdowns from full power, or by the changes that could have taken place due to exposure to the radiation field. Plotted among other data in Fig. 11 is the change of room-temperature electrical resistivity vs station of the composite elements at the start as compared to the end of the NF-1 test. At Station 200 the electrical resistivity increased by a factor of six, indicating radiation damage. The dotted portion of the resistivity curve has been sketched in, disregarding resistivity effects of midrange corrosion. The coating-crack curves of Fig. 9 were similar to the electrical resistivity curve, which suggested that the formation of coating cracks might be related to radiation damage.

Changes is. room-temperature thermal conductivity of whole element cross sections from station 200 were determined by a flashdiffusivity method. The average room-temperature thermal resistivity of five elements increased by a factor of 9.3. However, a sample from hot-end station 1110 had a thermal resistivity ratio (start/end) of only 1.5. Subsequent annealing studies on samples from station $\sim 200$ indicated that after one hour at 1500 to $1600 \mathrm{~K}$ most of the damage was removed, $i . e .$, both the room-temperature electrical and thermalresistivity ratios (start/end) decreased from 9.0 to 1.2. Because these annealing results were very similar to those obtained on fast-neutron-irradiated graphite by Taylor, Kelly, and Gilchrist ${ }^{4}$ the rasiation damage in the composite elements was assumed to be associated primarily with the graphite phase. At room temperature $\sim 108$ of the thermal conductivity of a couposite element can be attributed to the carbide phase.

The thermal conductivity of the ratrix as a function of temperature was dete mined by a laser flash-diffusivity techniqli:. Disks, $12 \mathrm{~mm}$ in diameter and $1 \mathrm{~mm}$ thick, were obtained at station $\sim 160$ from two similar elements, only one of which had been in the reactor. As shown in Fig. 12, the thermal conductivity of the irradiated matrix at the operating temperature $(800 \mathrm{k})$ for Station 160 had decreased from $40 \mathrm{~W} / \mathrm{m} \cdot \mathrm{K}$ at the start to $12 \mathrm{w} / \mathrm{m} \cdot \mathrm{K}$ at the end of the NF-1 test. The thermal conductivicy of this disk at temperatures above $800 \mathrm{~K}$ (solid curve, Fig. 12) is a function of the amount of annealing that occurred during the time the thermal-conductivity measurements were being taken. The higher thermal conductivity at $2300 \mathrm{~K}$ of the irradiated sample than that of the unirradiated sample is not understood.

The changes in thermal conductivity of the matrix caused commensurate changes in the steady state thermal gradients in the matrix. Figure 13 shows the calculated mean differential temperature between the matrix and the $\mathrm{zrC}$ channel coating as $a$ function of station. Note the large changes at the lower stations from the start to the end of the NF-1 test. The corresponding changes in strain, which increased about twofold, were high enough to exceed the 1000- $\mathrm{m} / \mathrm{m}$ strain limit of the coating. Thus, even steady state full-power conditions would cause the coatings to crack, let alone the strains developed during emergency shutdowns.

The curves in Fig. 11 outline the relationships among matrix temperature, neutron fluence, and fissions as a function of station. Studies of irradiated graphites ${ }^{4-6}$ have indicated that fast-neutron fluences of $10^{25}$ neutrons $/ \mathrm{m}^{2}$ (>0.18 MeV) would be required to change the ratio of thermal resistivity of graphite by a factor of 8 to 10 as in the NF-1 compoeite elements. However, because the fast-neutron fluence in NF-1 was only $5 \times 10^{22}$ neutrons $/ \mathrm{m}^{2}$ at station 160 (the station with the greatest radiation damage) the possibility of damage by fission-fragment interaction was considered. If the range of fission fragments in $(U, \mathrm{Zr}) \mathrm{C}$ is assumed to be 5 to $7 \mu \mathrm{m}$ and the web thickness of the carbide network 


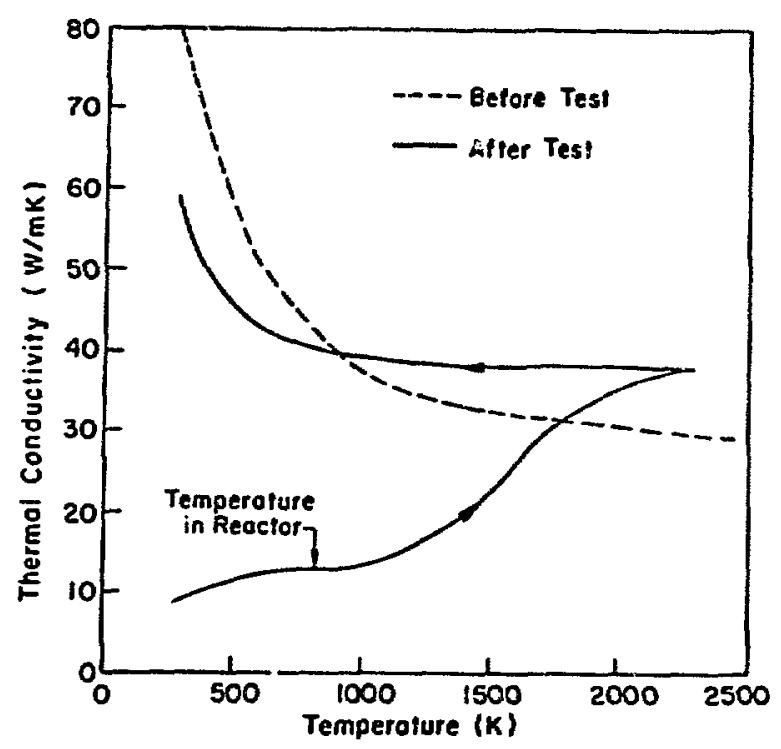

Fig. 12. Comparion of thermal conductivity vs temperature of a composite fuel-element matrix before and after testing in the NF-1 reactor.

is 5 to $10 \mu \mathrm{m}$ (Fig. 5), the probability of a fission fragnent entering the graphite phase is estimated to be $>0.1$. With $5 \times 10^{23}$ fissions $/ \mathrm{m}^{3}$ and double that number of fragments, at least $10^{23}$ fragments $/ \mathrm{m}^{3}$ interacted with the graphite at station 160 .

Table $V$ compares the dosages of fast neutrons, ${ }^{235_{v}}$ fission fragments, and the $\alpha$ and ${ }^{7} \mathrm{Li}$ particles from the ${ }^{20_{\mathrm{B}}(\eta, \alpha)^{7} \mathrm{Li}}$ reaction that produced a room-temperature thermal-resistivity ratio change of $\sim 10$ in graphite irradiated at 700 to $900 \mathrm{~K}$. Radiation damage of graphite by fast neutrons has been studied by numerous investigators, and all the results are in agreement that considerable damage is done at fiuences of $10^{25}$ neutrons $/ \mathrm{m}^{2}$. Radiation damage effects in borated graphite by $\alpha$ and ${ }^{7} \mathrm{Li}$ particles from the ${ }^{10} \mathrm{~B}(\pi, \alpha){ }^{7} \mathrm{Li}$ reaction were studied by Davidson, Gates, and Nightingale. 7,8 The boron carbide was dispersed throughout a graphite matrix as particles of 10-to 100-um diam. About 58 of the reaction products were estimated to be effective in causing displacement of carbon atoms. 9 The effect of ${ }^{235} \mathrm{v}$ fission fragments on the thermal conductivity of

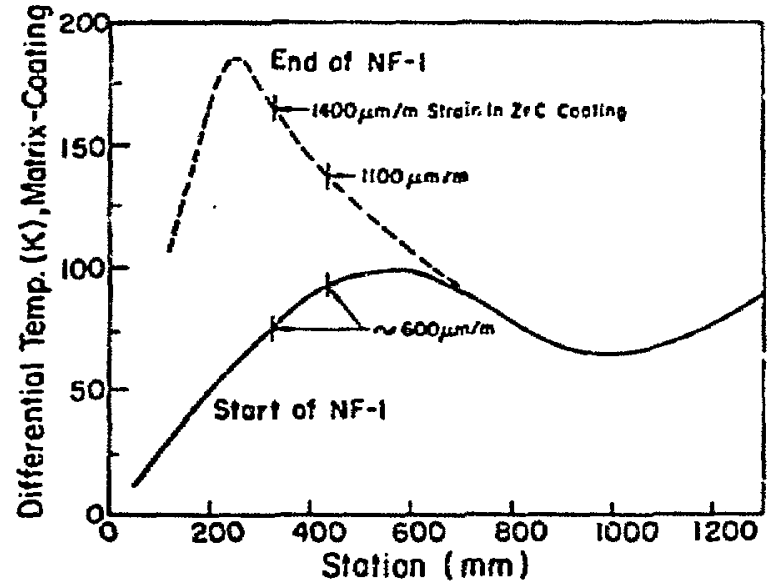

Fig. 13. Temperature cifferences between composite mairix and $\mathrm{zrC}$ protective coating and resultant coating strains at the start and end of the NF-1 reactor test.

\section{TABLE $V$}

COMPARATIVE STUDIES OF RADIATION INDUCED DAMAGF TO GRAPHISE AT 700 TO $900 \mathrm{~K}$

Dose in Graphite $\begin{gathered}\text { Temperature } \\
\text { of } \\
\text { Irtadiation. } x\end{gathered}$\begin{tabular}{c}
$\begin{array}{c}\text { Thersal- } \\
\text { Resistivity } \\
\text { Patio }\end{array}$ \\
\hline
\end{tabular}

\begin{tabular}{|c|c|c|}
\hline $\begin{array}{l}4.5 \times 10^{25} \text { neut } / \mathrm{m}^{2} \\
(>0.18 \mathrm{MeV}) \mathrm{B}\end{array}$ & $\begin{array}{l}725 \\
925\end{array}$ & $\begin{array}{l}9.7 \\
7.0\end{array}$ \\
\hline $\begin{array}{l}210^{25} \text { cambined } a \\
\text { and }{ }^{21} \text { particles } \\
m^{3} \text { from } 10_{\mathrm{B}}(n, a) \mathrm{Li}_{\mathrm{Li}} \\
\text { reactionc }\end{array}$ & 775 & 10 to 14 \\
\hline
\end{tabular}

$10^{24}$ fission $\quad 900 \quad 10$

fragments/m 235 fission ${ }^{d}$

$10^{23}$ fission

fragments/m

from $235 \mathrm{U}$ fission.

data from this report

aroon-temperature themai-resistivity ratlo bofore and after irradiation.

$b_{\text {PGA, a pile grade graphite. }}$

${ }^{c}$ Borated graphite. 7 Burnout was 5 to $25 \times 10^{26}$ atoms $10 \mathrm{~g} / \mathrm{m}^{3}$ with 25 of the reaction products effectively entering the graphite from $\mathrm{B}_{4} \mathrm{C}$ particles of 10-to 100-um diam.

dational Carbon Co. B-1508-A graphite containing 2- to 5 -um-dian $U_{3} O_{6}$ particles. 16 Dose was $3 \times 10^{24}$ fissions $/ \mathrm{m}^{3}$. 
graphite was studied by Runter, 10 using a

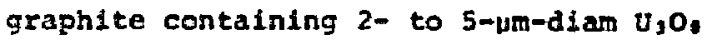
particles. The probability of fission fragments leaving these small particles and entering the graphite phase was high. Considering all the imponterable differences between flunter's experiment and the NF-1 experiment, the agreement within a factor of 10 of the influence of fission fragments on grapht te is considered good.

\section{IV. (U.25)C TCARAIDE) FUEL ELEMENTS}

Two of the 49 cells in the NF-1 zeacto: contained (U, Sr)C solfd-golution carbide elements, Fig. 14. Each cell contained seven elements, bundled together, as shown in Fig. 15, with another seven elements stacked on top to complese the length of the cell. The 28 carbide elements in the two cells represented three types of matrix experiments.

The carbide elements were extruded from a mix consisting of zrc powder, exItched $\mathrm{VO}_{2}$ powder. $2 \mathrm{rO}_{2}$ powder, graphite flour, and a themosetting binder. Solidsolution $\left(U, z_{r}\right) C$ was formed in the elements during a high-temperature heat treatment. The elements contained $\sim 3$ excess carbon to facilitate densification during heat treatment, to prevent sticking to graphite fixtures during heat treatment, and to aid in machining the elenents to a hexagonal cross section. The excess free carbon was removed by leaching with hot hydrogen gas. After leaching, the elements were impregnated with various amounts of zisconium by a chenical vapor-deposition process io adjust the carbon stoichiometry. A final

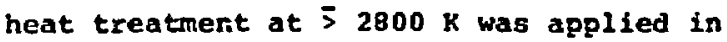
an attempt to obtain uniform chemical composition. Matrices that gained 0,3 , and 88 mass during the zirconium impregnation process were used in the NF-1 reactor experiment. Table VI presents the chemical analyses and property data for these elements. The carbon-to-metal ratio of the impregnated elenents was not as low as had

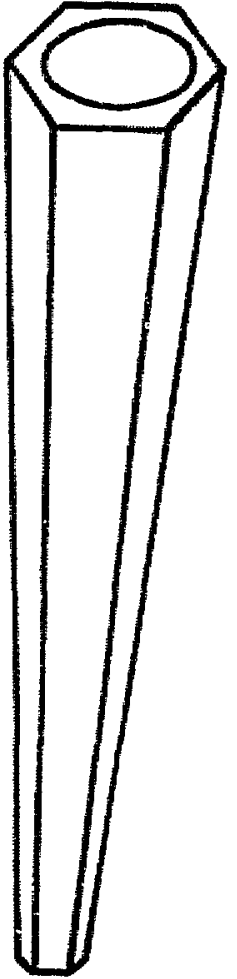

Fig. 14. Ful1-length view of $(0,2 r) c$ (carbide) fuel element. Length, $0.64 \mathrm{~m}$; across flats, $5.5 \mathrm{~mm}$; coolantchannel diameter, $3.2 \mathrm{~mm}$; and carbon/metal atom ratjo, 0.8 to 0.92 .

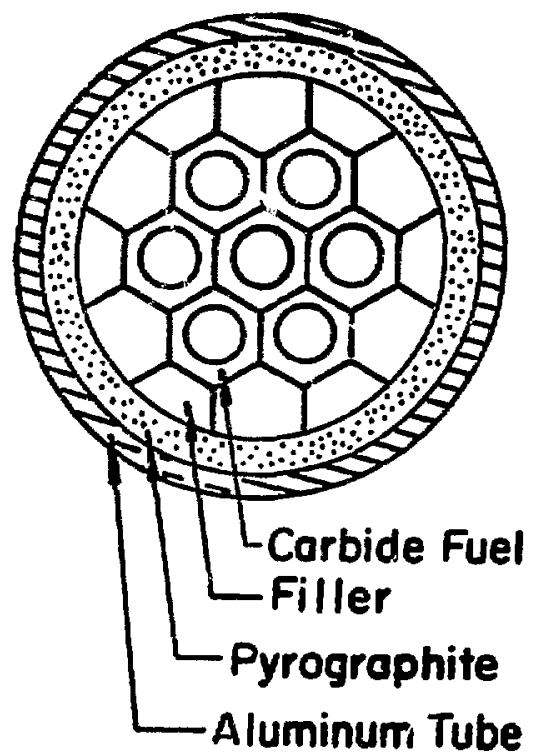

Fig. 15. NF-1 reactor cell containing $(U$, 2r) (carbide) fuel elements. The filler was zrc-graphite (composite) coated with zrc. 


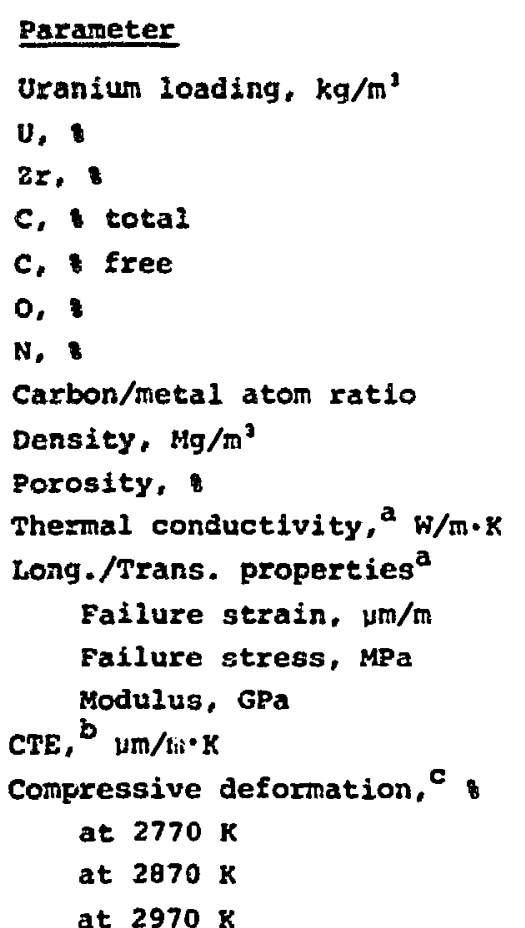

\begin{tabular}{|c|c|c|}
\hline 0 & 3 & 8 \\
\hline 2300 & $\approx 300$ & $\approx 300$ \\
\hline 5.88 & 5.64 & 5.42 \\
\hline 82.9 & 83.1 & 63.5 \\
\hline 21.0 & 11.0 & 10.8 \\
\hline$<0.05$ & $<0.05$ & $<0.05$ \\
\hline 0.05 & 0.07 & 0.04 \\
\hline 0.24 & 0.22 & 0.29 \\
\hline 0.981 & 0.980 & 0.958 \\
\hline 5.48 & 5.46 & 5.71 \\
\hline 23 & 21 & 18 \\
\hline 10.0 & 0.6 & 8.2 \\
\hline $10 / 460$ & $470 / 460$ & $300 / 450$ \\
\hline $40 / 75$ & $240 / 90$ & $100 / 95$ \\
\hline $50 / 160$ & $290 / 200$ & $330 / 210$ \\
\hline 7.8 & 7.8 & 7.8 \\
\hline- & 4 & 2 \\
\hline-- & - & 5 \\
\hline 26 & 20 & 7 \\
\hline
\end{tabular}

\footnotetext{
${ }^{a}$ Room temperature lcngitudinal and transverse properties. boefficient of thermal expansion, 293 to $2300 \mathrm{~K}$. $c_{6.9} \mathrm{MPa}$ for one hour.
}

been expected because of carbon pickup from the atmosphere of the heat-treatment

furnaces.

The temperatures at which liguid is formed in $\left(U_{0.1}{ }^{2 r_{0.9}}\right) C_{x}$ as a function of carbon stoichiometry are shown in Fig. 16.

A proposed maximum operating temperature of $3200 \mathrm{~K}$ is equivalent to a specific impulse of $2950 \mathrm{sec}$ in a nuclear propulsion engine using hydrogen as a propellant and, as indicated in Fig. 16, would require careful control of the carbon stoichiometry.
V. REACTOR PERFORMANCE OF CARBIDE ELEMENTS

The NF-1 full-power conditions affecting the carbide elements were essentially those listed in Table IV. The primary purpose of the carbide fuel-element experiment in the NF-1 reactor was to determine the fracture mode of the carbide elements at peak power densities up to $24500 \mathrm{MH} / \mathrm{m}^{3}$. Considerable transverse fracturing could be tolerated, but extensive longitudinal fracturing or fragmentation would cause operational difficulties, i.e.. plugged flow passages and hot spots. 


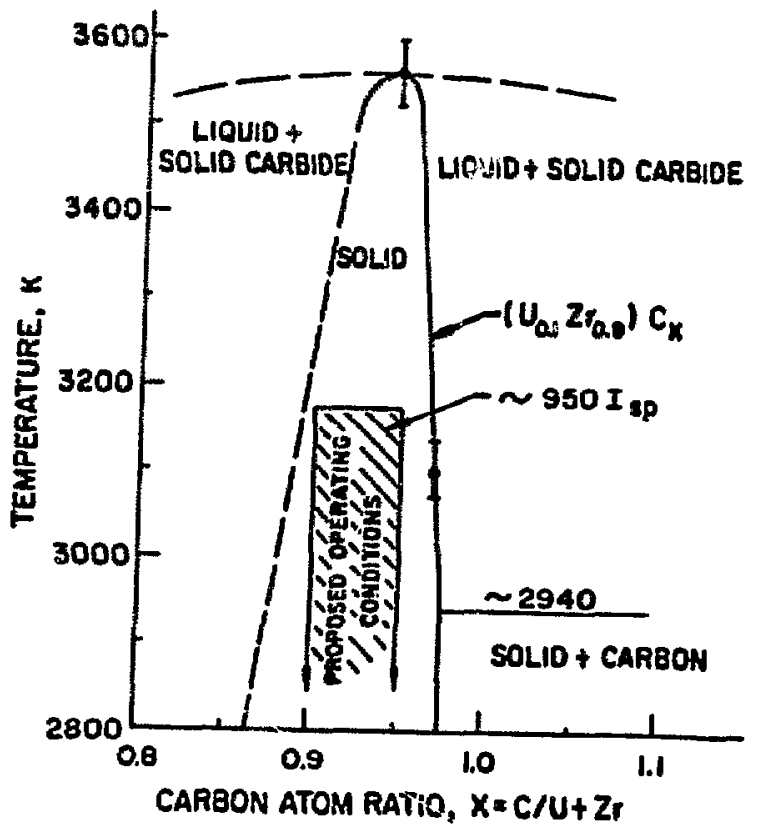

Fig. 16. Pseudobinary phase diagram for $\left(v_{0,1}{ }^{2 *} *_{0.9}\right) C_{x}$

The two thermocouple channels, which measured the exit-gas temperature from the twn cells of carbide elementa, behaved considerably different than the other channels. First, their temperatures were $\sim 100 \mathrm{~K}$ lower than the core average of $2450 \mathrm{R}$, either due to improper orificing or becauge of incorrectly predicted carbide-element power. Secondly, the two channels showed a greater variability with time than any other channel, exhibiting both long-term drifts and short-term fluctuations. The fluctuations may have been due to impedance variations, such as might be caused by fractured elements.

Before disassembling the two cells, steel skewers were inserted in the coolantchannel passages of the elements. The metal walls of the cells were split longitudinally and the elements were exposed to view. There were many traisgverse fractures, but no fragmentation into small-size particles.

The nonimpregnated elements, installed only in the cold-end section of the core
(Erom Station 0 to 650), had transyerse fractures at $5 \mathrm{~m}$ to $15-\mathrm{mm}$ intervalis [one to three fuel-element diameters, Fig. 17, (A) and (B)]. Microscopic examination of polished samples showed up to two longitudinal cracks per crose section from station 200 to station 550. There was considerable longitudinal and transverse fracturing -typically ahow in Fig. 17, (c) -- from station $\sim 500$ to 650 .

The 3t-impregnated elements, in both the cold and hot-end sections, had a similar fracture pattorn, except that the highly fractured region extended from station $~$ 500 to station $\sim$ 800. As many as four longitudinal cracks per cross section were counted in this region. At higher stations, 1000 to 1300 , the transverse fractures occurred at 25- to $50-m m$ intervals, with one longituainal crack per cross section occasionally.

The 88-impregnated elements, installed only in the hot-end section (from station 650 to 1300 ), dia not undergo as much fracturing as the other two types. At station 700 , where the peak power density was n $4500 \mathrm{MH} / \mathrm{m}$, the characteristic transverse fracture interval was o $25 \mathrm{~mm}$, and at higher stations fractures occurred sometimes only at 100-m intervals. Typical fractures are shown in Fig. 17, (D). Microscopic examination of polished sections indicated that some samples had no longitudinal cracks, even at Station 700, and at the most only one crack per cross section.

Although the extent of longitudinal cracking in the carbide elements was disappointing, their performance in retrospect was not unreasonable considering the low strain-to-fracture characteristics of the matrices, the high power density, and the thermal gradients developed during the two emergency siutdowns. New matrix development experiments have indicated that the strain-to-fracture characteristics of the carbide elements probably can be increased 

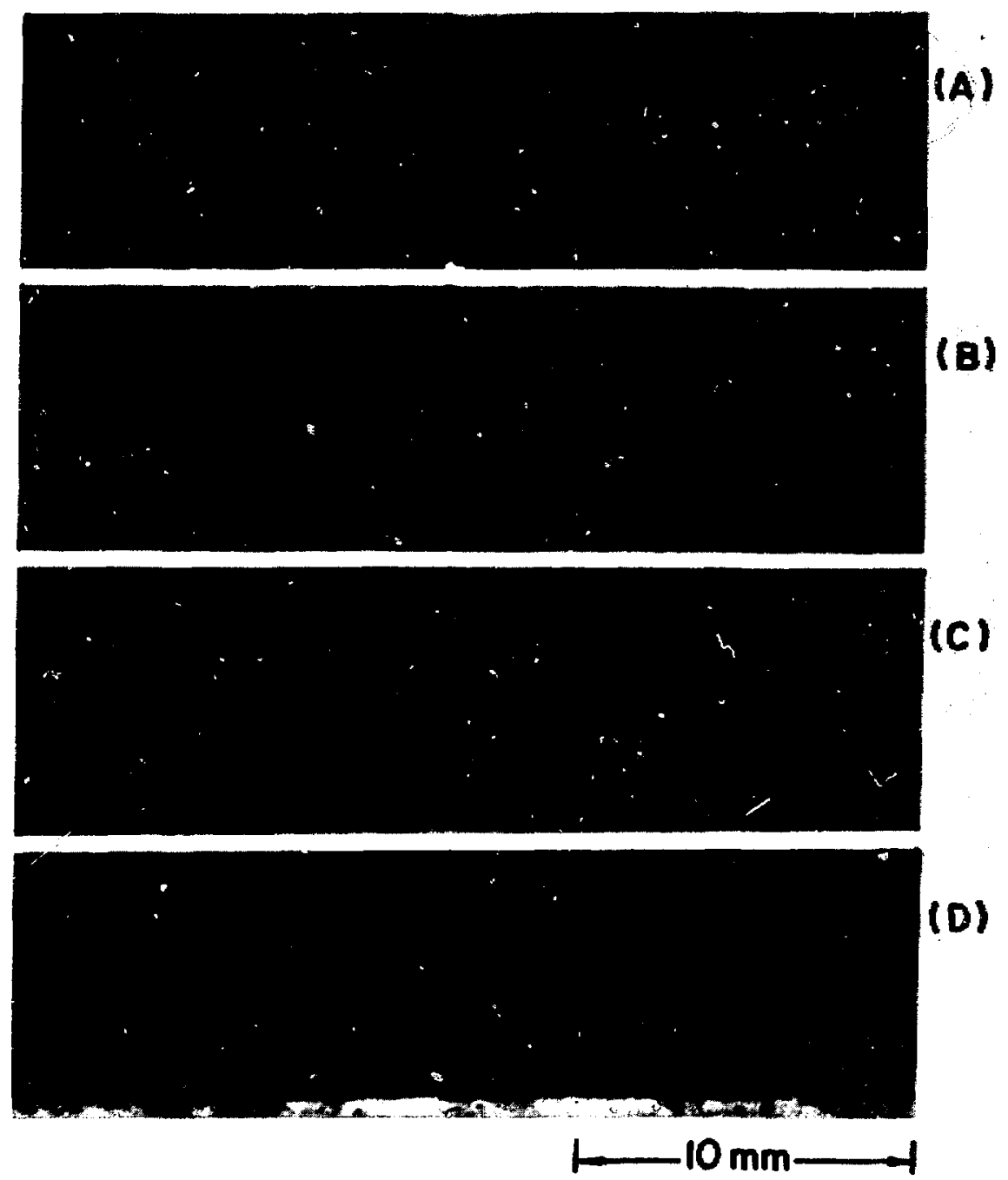

Fig. 17. Fracture patterns in NF-1 carbide elements: (A) and (B) show transverse fractures at low stations 0 to 600 ; (C) shows both longitudinal and transverse fractures with a piece removed, and (D) shows a transverse fracture at hich stations 700 to 1306 .

by a factor of two, i.e., to about 800 to $1000 \mathrm{\mu m} / \mathrm{m}$ versus 300 to $500 \mathrm{\mu m} / \mathrm{m}$ of the NF-1 carbide elements. Reducing the cross section and web thickness of the elements by 25 would substantially decrease the steady state temperature gradients. An improved matrix coupled with a modified design would siqnificantly increase the fracture resistance of carbide elements over that of those used in the $\mathrm{NF}-1$ reactor. Component tests have indicated that carbicie elements would perform for many hours at

\begin{abstract}
temperatures of 2800 to $3100 \mathrm{~K}$ without serious losses of $C, \mathrm{v}$, or $\mathrm{Zr}$.
\end{abstract}

\section{CONCLUSIONS}

\section{A. Composite Elements}

The mass losses of composite elements, because of the reaction of hydrogen with graphite, were very dependent on the formation of cracks in the protective $\mathrm{zrC}$ coating. Minimizing the thermal-expansion mismatch between the $\mathrm{arC}$ coating and the composite 
matrix reduced both the tendency to form coating exacks and the mass 10ss. Mass losses were unexpectedly high in those portions of the elements which had been damaged by radiation. This damage--apparentiy due to interaction of fisston fragments with the graphite--degraded the thormal transport properties of the matrix, and the resulting temperature gradients calsed extensive cracking of the coating. The composite elements withstood peak power densities of 4500 to $5000 \mathrm{~mW} / \mathrm{m}^{3}$ without major difficulties. In general, the NE-1 experiments indicate that composite elements (even those suffering the highest carbon 10ss) would perform satisfactorily for at least two hours in a nuclear propulsion reactor which heated hydrogen to the temperature region of 2500 to $2800 \mathrm{~K}$. The basic information leading to this conclusion is the constancy of the individual exit-gas thermocouple readings for each fuel element duxing the course of the NF-1 reactor operation. These readings were essentially constant for all composite elements; consequently, it could be concluded that even the highest carbon losses had not interfered with the proper functioning of the ejements concerned. An extrapolation of these results to longer reactor run times-ten hours for exanple-- is aifficult. Massive nonlinear and catastrophic carbon losses such as those previsusly observed for carbide-coated graphite elements would not be expected. What might occur in a nuclear propulsion reactor (in which, unlike the conditions in NF-1, element-to-element interactions could be of importancel is transverse fracturing of some elements, due to repeated temperature cycling, in the resion from which the most carbon hitd been removed and thereby weakened; IFig. 28 shows the change in flexure strength due to midrange mass losses). Such fractures cculd cause radial cross-flow of hydrogen among coolant channels, particularly for those elements which had a large variation in inlet orifice sizes. Therefore, matrix

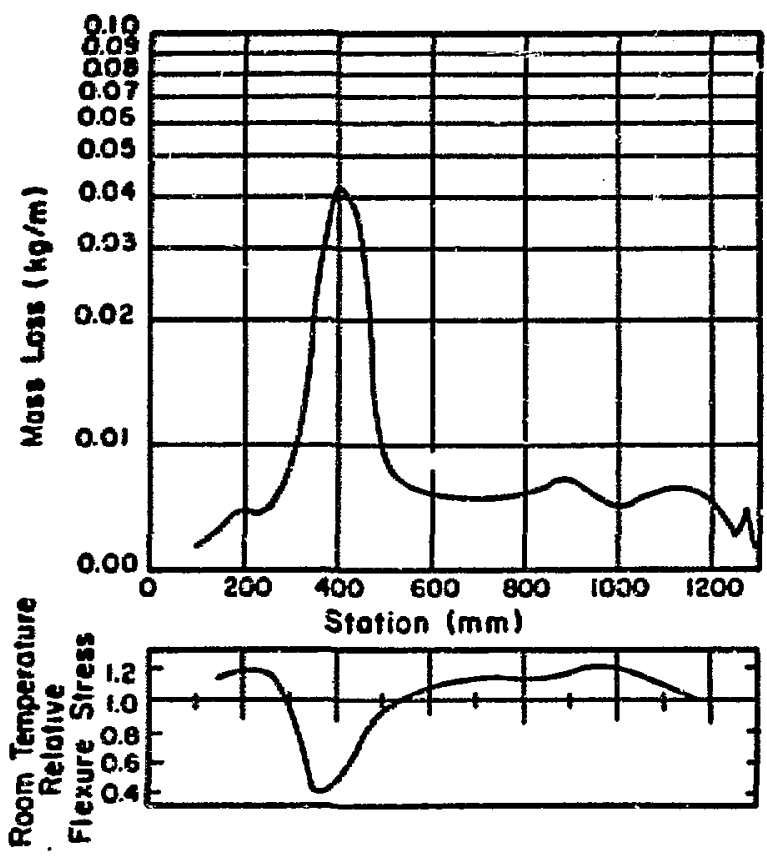

Fig. 18. Changes in room-temperature flexure stress-to-fracture of NF-1 composite elements relative to the fracture strength before the NE-1 test.

temperatures might increase locally. The conseguences of such local temperature increases are not easily determined. The useful life of composite elements, of the high-CTE matrix type with the lowest mass losses in the NF-1 reactor, is certainly longer than two hours, probably two to three times as long.

\section{B. Carbide Elements}

The carbide elements in NF-1 cracked extensively, particulariy near the center of the reactor where the peak power densities were $\sim 4.500 \mathrm{MH} / \mathrm{m}^{3}$ and the temperature was 1500 to $1800 \mathrm{~K}$. No evidence of fragmentation inco millimeter-size particles was seen. Improvements in strain-tofracture properties of the matrix, and design changes to minimize temperature gradients, would make these elements useful at power densities of 2000 to $4000 \mathrm{MW} / \mathrm{m}^{3}$. 


\section{Reactor Performance of Composite vs Graphite Elements}

The mass-loss behavior of composite elements cannot be compared directly with that of graphite elements becauge the two types of elements were never tested in the same reactor. However, the performance of graphite elements tesced in the Pewee 1 reactor can be compired with that of composite elements in the NF-1 test. The run time of the Pewee 1 reactor was $40 \mathrm{~min}$ versus $109 \mathrm{~min}$ for the $\mathrm{NE}-1$ reactor. The time-average coolant-channel surface temperature at Station 1000 was 2575 and $2475 \mathrm{~K}$ for the two reactors, i.e., the test temperature in the Pewee 1 reactor was $\sim 100 \mathrm{~K}$ higher than in the $N F-1$ reactor. The average fuel-element power density was 1.2 and $0.9 \mathrm{MW} / \mathrm{element}$ for the Pewee 1 and NF-1 tests, respectively. The coolant channels from Station 800 to 1300 of the graphite elements in the Pewee 1 reaccor were coated with either a $\mathrm{NbC}$ or a $\mathrm{ZrC}$ coating of $\approx 75$ um thickness, whereas the coolant channels at these stations of composite elements in NF-1 were coated with a ZrC coating of 100 to $150 \mathrm{\mu m}$ thickness.

Figure 19 presents the average mass loss rates per unit surface area of coolant channel as a function of station for Pewee-1 and NF-1 elements. The average losses in the miarange section were similar for all types of elements; however, these losses were quite variable for individual elements. The CTE of the graphite fuel-element matrix, containing pyrocarkon-coated $\mathrm{UC}_{2}$ spheres, was $\sim 5 \mathrm{\mu m} / \mathrm{m} \cdot \mathrm{K}$ as compared to $\sim 6.6 \mathrm{\mu m} / \mathrm{m}^{*} \mathrm{~K}$ (293-2300 $\mathrm{K}$ range) for the high-CTE type composite matrix. The strain capability of the coatings on the graphite elements was exceeded on cooldown from the temperature used in the coating deposition process, and the coolant-channel coatings of these elements therefore cracked extensively. Apparently, the mass-loss rates in the midrange section of both types of elements were due to the presence of coolant-channel

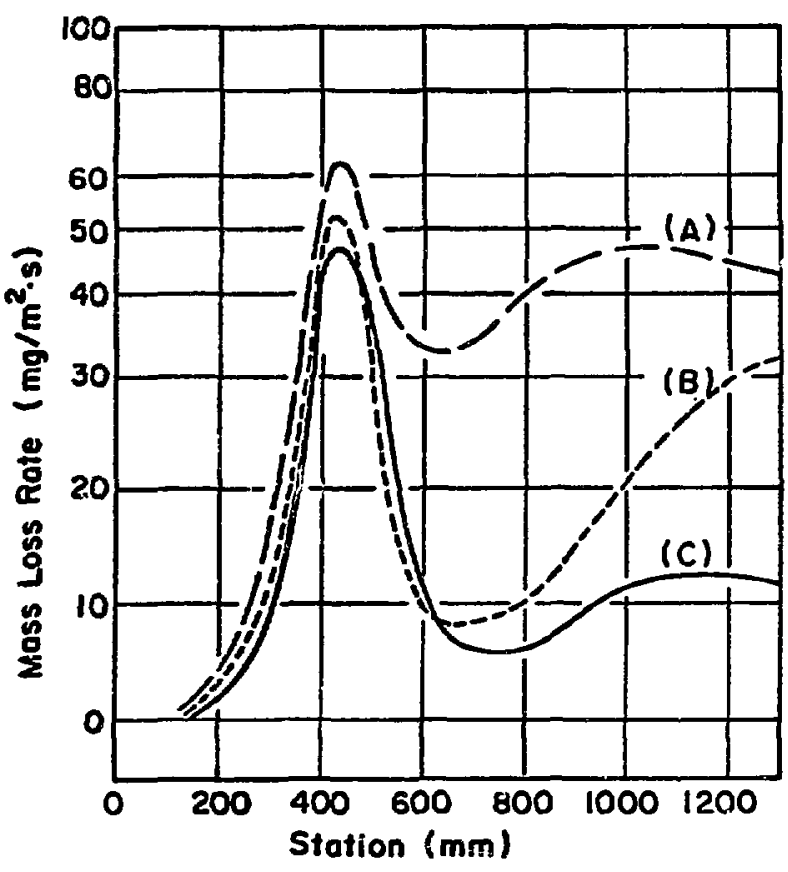

Fig. 19. Mass loss rates per unit surface area of coolant channel vs station for graphite and composite elements: (A) average for 102 Pewee-1 graphite fuel elements coated with $\mathrm{NbC}$, (B) average for 12 Pewee-1 graphite fuel elements coated with ZrC, (C) average for $23 \mathrm{NF}-\mathrm{l}$ highCTE composite fuel elements coated with ZrC, adjusted to the Pewse-1 test temperature.

coating cracks regardless of the mechanism by which these cracl:s had been formed (mismatch of matri:" and carbide coating CTE, effects of emergency shutdowns, or radiation danage to the matrix).

The hot-end mass loss rates of the NbCcoated graphite elements in Pewee 1 were considerably higher than those of comparable zrc-coated graphite elements. This difference was expected because of the higher diffusion coefficient of carbon through NbC than through zrc. The hot-end mass loss rates of $\mathrm{zrC}-$ coated high-CTE type composite fuel elements in NF-1 were lower than those of the graphite elements even after adjustment for the difference in operating temperatures between the two reactors (based on the data of Fig. 8: - the 100- $\mathrm{K}$ aifference in bore 
surface temperature between the two reactors results in a hot-end mass loss rate which, for the Pewee 1 reactor, is 1.5 times higher than for the NF-1 reactor). These lower hot-end mass loss rates of the NF-1 elements undoubtedly were due, in part, to the increased thickness of the $\mathrm{arC}$ coatings in the NF-1 elements.

The assumption used in this comparison of graphite vs composite elements is that the mass loss rates are linear with respect to time and amount of mass loss. Previous reactor tests with graphite elements indicate a high incidence of catastrophic erosion if mass losses were high. However, the presence of a continuous carbide network in composite elements has prevented erosion both in component tests and in the NF-l test. In component tests, these elements have noi shown any substantial change in mass loss rate as a function of test time.

The graphite fuel elements would not have undergone degradation of properties by interaction of fission fragments with the matrix because the range of the fission fragments would not have exceeded the dimensions of the pyrocarbon-coated $\mathrm{UC}_{2}$ particles. In addition, radiation damage to the graphite fuel element by fast-neutron fluence is considered to become important only after several hundred hours of operation in a nuclear propulsion reactor. To reduce the losses in the midrange section of graphite elements, the CTE of the matrix should be increased to $\sim 7 \mu \mathrm{m} / \mathrm{m} \cdot \mathrm{k}$. Recent developments at Union Carbide's Y-12 plant at Oak Riage may eventually have resulted in a much improved high-cTE element. 11

The usefulness of composite elements is limited by their high susceptibility to radiation damage. However, whereve: resistance to erosion is a requirement, their performance is highly superior to that of graphite-matrix fuel elements.

\section{APPENDIXES}

Attached are Appendixes A through E, which summarize the development history of the $(U, Z r) C$-graphite and carbide fuel elements. The results of detailed evaluation studies of composite elements are also included.

\section{ACRNOWLEDGMENTS}

This work was sponsored by the U.S. Atomic Energy Commission under Contract $w-7405-E n g-36$. The author wishes to thank the numerous individuals who contributed to this work: C. Bankston, R. Bard, A. Driesner, K. Davidson, J. Rowley, and T. Wallace of the Rover Fuel Element Committee; F. Criss, A. Driesner, D. MacMillan, W. Martin, $D$. Schell and $A$. Zerwas for development and fabrication of the elements; J. Fullbright, D. Garrett, T. Gregory, R. Strong, and M. Winkler for nondestructive evaluation; H. Filip, C. Hoffman, R. Lawton, H. Murphy, B. Morrison, W. Prince, and I. Wahman for property and component testing; I. Leffler, A. Pereira, and D. Rose for reactor postmortem operations; B. Fisher, R. Milenfant, and R. MCFarland for analytical calculacions; and the members of Group CMB-1 for chemical analyses. 


\section{REFERENCES}

1. W. L. Kirk, "Nuclear Furnace-1 Test Report," Los Alamos Scientific Laboratory Report LA-5189-MS (1973).

2. K. V. Davidson, W. W. Martin, D. H. Schell, J. M. Taub, and $J . W$. Taylor, "Development of Carbide-Carbon Composite Fuel Elements for Rover Reactors," Los Alamos Scientific Laboratory Report LA-5005 (1972).

3. M. A. Winkler and H. J. Fullbright, "Improved Method of Fuel Element Incremental Mass Measurement," Los Alamos scientific Laboratory Report LA-4105 (1969).

4. R. Taylor, B. T. Kelly, and K. E. Gilchrist, "The Thermal Conductivity of Fast Neutron Irradiated Graphite," phys. Chem. Solids 30. 2251 (1969).

5. W. H. Martin and A. M. Price, "Determination of Dose Temperature in Graphite Irradiation Experiments in the Dounreay Fast Reactor," J. Nuclear Energy 21, 359 (1967).

6. G. B. Engle and K. Koyama, "Thermal Conductivity Changes in Nuclear Graphites at High Temperatures and High Fluences," Gulf General Atomic Co. Report Gulf-GA-Al2137 (1972).

7. J. M. Davidson, L. O. Gates, and R. E. Nightingale, "Radiation-Damage Effects in Borated Graphite," Nucl. Sci. Eng. 26, $90(1966)$.

8. J. M. Davidson and I. O. Gates, "Boronated-Graphite Irradiation Studies--Final Report of Irradiation Experiments Conducted in a Hanford Reactor," Battelle-Northwest Report BNWL-96 (1965).

9. R. E. Dahl, "Correlation of Radiation Damage in Boronated Graphite," Battelle-Northwest Report BNwL-199 (1966).

10. L. P. Hunter, "Effect of Fission Recoil Fragments on the Thermal Conductivity of Graphite," J. Appl. Phys. 30, 1969 (1959).

11. J. M. Napier, "NERVA Fuel Element Development Program Sumnary Report - July 1966 through June 1972: Extrusion studies," Union Carbide Oak Ridge Y-12 Plant Report Y-1852, Part I (1973). 


\section{APPENDIX A}

HISTORY OF LASL DEVELOPMENT OF CARBIDE-GRAPHITE

COMPOSITE STRUCTURAL MATERIALS; (U, Zr)C-GRAPHITE (COMPOSITE) FUEL ELEMENTS: AND $(\mathrm{U}, \mathrm{Zr}) \mathrm{C}$ FUEL ELEMENTS

\section{INTRODUCTION}

The need for structural materials that would withgtand the Rover reactor core environment better than $\mathrm{NbC}-c o a t e d$ graphite was recognized early in 1962, Niobiumcarbide coated graphite was used as part of the structural support of the core but was subjected to attack by flowing hydrogen gas at temperatures up to $2800 \mathrm{~K}$. The NbCcoated graphite lost mass by the carbonhydrogen reaction and, at times, experienced considerable erosion. The main difficulties with this material were attributed to the poor adherence of the NbC to the graphite and to the presence of numerous cracks in the coating.

Composites of carbide and graphite were developed to replace NbC-coated graphite and were used is fuel-element tips, support pedestals, support cups, support elements, and peripheral filler elements. Where neutronic considerations were not important, e.g., at the end of the reactor core, composites containing TaC, NbC, or mixtures thereof were used. Zirconium-carbide graphite composites were used at all locations where neutronic considerations were important, The structural composites were coated with a rac, $\mathrm{NbC}$, or ZrC protective coating of 50 to $100 \mathrm{\mu m}$ thickness. These coatings, when deposited on the composites, were very adherent and afforded much better protection to hydrogen attack than on graphite.

The success of structural components made from carbide-graphite composites led to the development of both the $(U, \mathrm{Zr}) \mathrm{C}$ graphite (composite) and all-carbide types of tuel elements. The main objective was the development of fuel elements which would be highly resistant to hydrogen attack and could be used at high operating temperatures. The composite fuel element retained the geometry of the old graphite element, but the allcarbide fuel element, which consisted of $(U, \mathrm{Zr}) \mathrm{C}$ substoichiometric in carbon had to be redesigned. The all-carbide element was expected to have excellent resistance to hydrogen attack, but would have low thermalstress resistance. Achieving a balance anong thermal-stress resistance, high-temperature performance, and resistance to hydrogen attack was one of the goals throughout the entire development of structural composites, composite fuel elements, and allcarbide fuel elements. However, in the case of all-carbide elements, it was recognized from the start that its resistance to thermal stress would be $s$ low that cracking and breaking during reactor operation could not be avoided, but it was thought possible to restrict thermal-stress cracking to tolerable levels by changing the geometry to a thinner element with only one coolant channel.

\section{CARBIDE-GRAPHITE COMPOSITE STRUCTURAL MATERIALS}

In November 1962, Union Carbide Nuclear Corp. ( $\mathrm{Y}-12)$ made some experimental nozzles for NASA from composite containing carbide and graphite. The nozzles were made by a cold press-sinter technique using graphite filler flour, Varcum binder, and either TaC or NbC carbide powder. The carbide content ranged from 0 to 1008 . Samples of these materials were submitted in January 1963 to LASL for possible use in the Rover program. 
In late 1963 and all through 1964, small-scale cooperative experiments were conducted by $\mathrm{Y}-12$ and IASL on the usefulness of carbide-graphite composites as fuel-element tips. NbC- and TaC-yraphite composites were made by cold press-sintering and extrusion techniques at Y-12 from June 1963 through 1965, whereas during this time IASI was fabricating carbide-graphite composite materials by hot-pressing ${ }^{A l}$ and by extrusion $^{\mathrm{A} 2}$ techniques. Also, in early 1964 , Illinois Institute of Technology and Research (IITR) began an independent study of the fabrication process and of the properties of hot-pressed carbide-graphite composites. In February 1965, LASL formed a committee to guide the development activities relating to carbide-graphite composites.

During this exploratory work, the advantages of composite materials containing 50 to 80 vols carbide (e.g., their adequate structural strength at temperatures up to $2800 \mathrm{~K}$, excellent adherence of vapor-deposited carbide protective coatings, and retention of some structural integrity upon loss of carbon due to diffusion through the coating or through coating defects! were recognized for possible use in Rover reactors. Acceptable thermal-stress resistance was obtained in structural applications by adjusting the amount of carbide and by designing the parts so that only low-temperdture gradients would arise in either steady state or transient conditions. The first reactor use of these carbide-graphite composite support materials was planned as a IASL experiment in the NERVA program's NRXA-6 reactor in the form of support pedestals, fuel-element tips, and special cups for use with graphite support blocks. Due to reasons not connected with these plans, only the cups were used in the NRKA-6 reactor. The reactor was run on December 15, 1967, and the composite cups performed satisfactorily. Later, complete dependence on composites was initiated for the hot-end support hardware in the Pewee 1 reactor including pedestals, fuel-element tips, support-element tips, and cups. The IASL and WANL designs of these units were slightly different, but in all cases the composite support hardware performed quite well in the December 1968 Pewee 1 test. ${ }^{\mathrm{A} 3}$ Composite support hardware was also fabricated for the Pewee 2 and $\mathrm{NF}-\mathrm{i}$ reactors.

\section{III. (U,ZI)C-GRAPHITE (COMPOSITE)} FUEL ELEMENTS

The use of uranium carbides as a component of fuel elements for nuclear propulsion reactors was discussed from the very beginning of the Rover program. on May 15, 1956 , the fabrication of parts for the first Rover reactor was discussed in a LASL conference. At that time the reactor design had advanced far enough to specify the use of flat plates of graphite as fuel elements. Much of the discussion, however, centered on the problem of incorporating $\mathrm{UC}_{2}$ into these plates and on the expressed doubt that the $\mathrm{UC}_{2}$-graphite system might not be satisfactory at temperatures of $\overline{>} 2770 \mathrm{~K}$ because of the formation of a eutectic melt at $2725 \mathrm{~K}$. The possible use of $(\mathrm{U}, \mathrm{Zr}) \mathrm{C}$ solid-solution carbide as a replacement for: $\mathrm{UC}_{2}$ was therefore also discussed at that meeting. The melting point of $80 \mathrm{wt} / \mathrm{zrC}$ mixed with 20 wto UC ( 10 molo UC) in the presence of excess carbon was thought to be in excess of $2970 \mathrm{~K}$, and such a material was expected to be better suited for use in graphite elements than $\mathrm{UC}_{2}$. However, the first fuel elements were made by impregnating graphite plates with a solution of uranyl nitrate and subsequent heat treatment formed $\mathrm{UC}_{2}$ particles. Solid-solution carbide dispersed throughout the graphite was not used.

The first Rover reactor tests were primarily engineering feasibility tests, and extruded graphite fuel elements contajning dispersed $\mathrm{UC}_{2}$ continued to be used for these early test reactors.

In April 1962 the use of graphite fuel elements containing finely dividea $\mathrm{UC}_{2}$ was discontinued, primarily because of the 
problems associated with hydrolysis of the $\mathrm{UC}_{2}$ with the moisture in air. The fuel elements used thereafter until 1969 in six nuclear propulsion test reactors of the Riwi, Phoebus, and Pewee design had a graphite matrix containing pyrocarbon-coated $\mathrm{UC}_{2}$ spheres of $\sim 150 \mu \mathrm{m}$ maximum diameter. Not only did the coated spheres solve the hydrolysis problem, but their use allowed the application of $\mathrm{MbC}$ or ZrC coatings, by a chemical vapor-deposition process, to the coolant channels. However, mass losses of carbon from the elements at the end of one hour of component or reactor testing were high enough to cause doubts as to whether graphite eiements could be used for longer periods of time. As outlined below, the search for fuel elements that had more resistance to carbon mass losses than graphite elements began in 1965.

From 1964 to 1966, extruded 19-hole hexagonal 50-voli composite elementw were made, both at $\mathrm{Y}-12$ and LASL, by using NbC or TaC carbides. These elements were fabricated primarily as an experiment to evaluate the usefulness of extruded material for fuel-element tips as compared to hotpressed material. In the course of this evaluation, an attempt was made to run 50volz-carbide elements in normal hydrogen corrosion tests. On rampup to full-power conditions of $0.9 \mathrm{MW}$ these elements developed longitudinal cracks terminating in several transverse cracks. The formation of these cracks was interpreted as being due to the relatively low thermal-stress resistance of the composites as compared to that of graphite fuel elements. Exploratory extrusions were made at IASL in the last half of 1965 beginning the development of (U,Zr)C-graphite elements. In 1967, a laboratory component test was perfected which evaluated the thermal-stress resistance $^{\mathrm{A} 4}$ of Rover fuel elements. In August 1967, a program of evaluating the thermalstress resistance of composite elements as a function of carbide content was started. Early in 1968, the results from the Labor- atory thermal-stress study indjcated that 20- and 30-vol8-NbC composite elements and the standard graphite elements had comparable thermal-stress resistances. These encouraging results, along with the excellent adherence of protective coatings on composites and the resistance of composites to disastrous corrosion and erosion attack by hydrogen, led to a decision in early 1968 to accelerate the development work on composite elements. The carbiaje chosen for use in composite fuel elements was $(\mathrm{U}, \mathrm{Zr}) \mathrm{C}$ because of its advantageous neutronic and high-temperature properties. simultaneously, work was started on the chemical-vapor-deposition techniques of applying $\mathrm{zrC}$ coatings both to the standard graphite and to the (U,Zr)c-graphite elements, and in June 1968, the efforts of the Rover materials program at LASL were concentrated on the development of the $(U, \mathrm{Zr}) \mathrm{C}$-graphite fuel elements. Considerable work ${ }^{\mathrm{A5}-\mathrm{A7}}$ was done by General Electric (Evandale) in 1963-1965 investigating the usefulness of loading graphite Rover elements with $(\mathrm{U}, \mathrm{Zr}) \mathrm{C}$ solid solutions. Most of their work consisted of extrusions starting with $(\mathrm{U}, \mathrm{Zr}) \mathrm{C}$ solid solutions rather than forming the solid solution in situ. Due to oxidation problems during the early stages of fabrication, the mechanical properties of the final elements were relatively poor. In addition, disproportionation of the $(U, \mathrm{Zr}) \mathrm{C}$ solid solution into $\mathrm{UC}_{2}$ developed during the final high-temperature heat treatment with subsequent hydrolysis problems due to reaction of the $\mathrm{UC}_{2}$ with moisture in air. This disproportionation was attributed to the use of 30- to 50-mols uC in the solid solution. In their final work with $(U, \mathrm{Zr}) \mathrm{C}$ solid solutions of < 20 molo UC, General Electric experienced very little disproportionation into $\mathrm{UC}_{2}$ and very little hydrolysis. In the type of composite elements fabricated at LASL, the concentration of $\mathrm{UC}$ in the final solid solution formed was $\overline{<} 14$ molo.

As mentioned earlier, the Pewee 1 reactor tested in December 1968 contained 
experimental composite support materials; however, the fuel elements were of the old graphite type loaded with pyrolytic-carboncoated $\mathrm{UC}_{2}$ spheres. The next reactor, Pewee 2, was planned to test new types of fuel elements and many forms of composite support materials. The Pewee 2 reactor was never tested because of funding and environmentalimpact difficulties. However, the following list of core components, fabricated and assembled into the Pewee 2 reactor, indicates the number of composite experiments in the reactor.

Number

$\sim 175$

$\sim 225$

100

$\sim 25$
Description

\section{(U, Zr) C-C, 30-voli carbide, ex-} truded composite fuel elements.

High-CTE graphite-matrix fuel elements containing coated $\mathrm{UC}_{2}$ particles from WANL and $\mathrm{Y}-12$.

zrC-C, 36-voli carbide, extruded composite support elements.

zrc-C containing $\sim 300 \mathrm{~kg} / \mathrm{m}^{3} \mathrm{TaC}$, 36-voli carbide, extruded composite support elements used as neutronic shims.

$127 \mathrm{TaC} / \mathrm{NbC}-\mathrm{C}, 46$-vol\& carbide, hotpressed composite pedestal-cup assemblies.

$\sim 80$

2rC-C, 30-vol: carbide, extruded filler elements for the core periphery.

All composite materials were fabricated at IASL. The composite fuel, support, and filler elements were coated with $\mathrm{ZrC}$ and the pedestal-cup assemblies were coated with TaC. The fabrication and assembly of Pewee 2 was completed by the summer of 1971 .

During 1970 the design of a small reactor (NF-1) for use as a materials test vehicle was completed. Forty-seven composite elements, 28 all-carbide elements, and several composite support materials experiments were fabricated for use in this reactor. The NF-1 reactor was tested in the summer of 1972 and the results of this test are a part of this report.

\section{IV. (U,2r)C, ALL-CARBIDE FUEL ELEMENTS}

Throughout 1965 the possibility of using an all-carbide fuel element as a means to reduce and perhaps eliminate carbon mass losses began to be considered seriously. Attempts were made to extrude small singlehole carbide-graphite composites containing large amounts of carbide. In December 1965 , tubes of $\sim 7 \mathrm{~m}$ diameter were extruded, using $\mathrm{UO}_{2}$ and $\mathrm{ZrC}$ as starting materials in an attempt to produce an all-carbide fuel element. Throughout 1966 parametric studies were conducted to develop information concerning the effect of starting materials and extrusion conditions on the properties of the elements, i.e., strength, shrinkage during processing, density, etc. At the end of these studies the advantages of retaining v 3 wto free carbon in the fuel element after the final high-temperature heat treatment became evident. This quantity of carbon aided in the extrusion process, controlled shrinkage and matrix microstructure, prevented sticking of the elements in the graphite fixtures used during heat treatment, and improved the machining characteristics of the elements.

In 1967 and 1968 carbide elements were made by using $\mathrm{ZrO}_{2}$ and $\mathrm{UO}_{2}$ rather than $\mathrm{zrC}$ and $\mathrm{UO}_{2}$ mixtures. The elements made with $\mathrm{ZrO}_{2}$ had very excellent strength properties and high densities. However, the shrinkage and strength of these extrusions was so unpredictable, depending on the source of the $\mathrm{ZrO}_{2}$, that this approach was dropped. Elements made from $\mathrm{ZrC}, \mathrm{UO}_{2}$, and small amounts of $\mathrm{ZrO}_{2}$ were then developed, and their shrinkage and final density properties were reproducible. These elements contained $\approx 3$ wt: free carbon, and the carbon and void space occupied $\sim 25$ vols of the matrix gross volume. 
In 1969 attempts were started to develop processes to remove the free carbon from the elements and to achieve matrices substoichiometric in carbon. Impregnation of the matrices with zirconium, by using a modification of the techniques developed for chemical vapor deposition of 2 rC protective coatings, was started. Eventually a process was developed where a combination of leaching out the free carbon with hydrogen and then impregnating the matrix with zirconium resulted in matrices substoichiometric in carbon.

In June 1970, a series of carbide elements Was made by using ${ }^{235} \mathrm{U}$ of 938 enrichment, with uranium loadings from 200 to $1300 \mathrm{~kg} / \mathrm{m}^{3}$. This series of elements was used to detect and identify any fabrication problems as a function of uranium loading. Foliowing this work, 4000 carbide elements, containing $\sim 3$ wto free carbon, were fabricated in late 1970 for use in neutronic experiments pertaining to reactors of the Pewee design (critical mass of $\sim 40 \mathrm{~kg}$ of 938 enriched ${ }^{235} \mathrm{v}$ ).

Throughout 1971 and in early 1972 carbide elements were fabricated for use in the NF-1 reactor with results as described in the main body of this report.

\section{REFERENCES}

Al. R. V. Davidson, R. E. Riley, and J. M. Taub, "Carbide-Graphite Composites," Los Alamos Scientific Laboratory Report LA-3659-MS (October 1966).

A2. R. E. Riley, N. K. Richerson, and D. H. Schell, "Extruded CarbideGraphite Composites," Los Alamos Scientific Laboratory Report LA-4077 (1969).

A3. "Pewee 1 Reactor Test Report," Los Alamos Scientific Laboratory Report LA-4217-MS (August 1969).

A4. R. G. Lawton and W. R. Prince, "Rover Graphite Fuel Element Thermal Stress Experiments and Analyses," Los Alamos Scientific Laboratory Report IAA-3849-MS (July 1968).

A5. "2nd Annuai Report of High Temperature Materials and Reactor Components Development Program," General Electric Co., Evandale, Ohio, Report GEMP-177B, Vol. II, pp. 299-232 (February 1963).

A6. "3rd Annual Report of High Tempexature Materials and Reactor Components Development Program," General Electric Co., Evandale, Ohio, Report GEMP-270B, Vol. II, Pp, 124-143 (February 1964).

A7. "4th Annual Report of High Temperature Materials and Reactor Components Development Program," General Electric Co., Evandale, Ohio, Report GEMP-334B, Vol. II, pp. 183-189 (February 1965). 


\section{APPENDIX B}

A COMPREHENSTVE STUDY OF COMPOSITE FUEL ELEMENT MATRICES: THE NF-1 EXPERIMENT

\section{INTRODUCTION}

Extensive effort was devoted at LASL toward the development of a $\left(U_{0}, Z r\right) c-g r a p h i t e$ (composite) matrix, with the goal of producing fuel elements of acceptable thermal stress resistance whose 2 rC coatings would remain crack-free even after simulated or actual reactor testing. The general approach was (I) to improve the thermal-stress resistance of elements by heat-treating the matrix to increase the thermal conductivity and to develop a strong interconnected carbide network, and (2) to increase the matrix longitudinal coefficient of thermal expansion (CTE) to at least $7 \mu \mathrm{m} / \mathrm{m} \cdot \mathrm{K}$ (293 to $2300 \mathrm{~K}$ range) by increasing the volume content (voli) of carbide and by the use of high-CTE filler flours, both of which should minimize the mismatch between the matrix and the $\mathrm{ZrC}$ coating (whose CTE is $\sim 7.7 \mu \mathrm{m} / \pi \cdot \mathrm{K}$ ).

The goal was attained only occasionally because of difficulties in obtaining proper heat-treatment conditions. These difficulties were due to the sensitivity of composite matrix properties to heat-treatment temperature and to difficulties of controlling the temperature of the heat-treatment furnace. Nevertheless, 35-vols carbide composite matrices were manufactured ruccessfully with a CTE of $\sim 6.8 \mu \mathrm{m} / \mathrm{m} \cdot \mathrm{K}$ and with thermal-stress resistances greater than those required for elements in a typical nuclear propulsion reactor of the Pewee and Phoebus designs.

The high-CTE filler flours used in this study $[K X-88, J M-15, G L-1076$, and POCO (I.F.)] are described in detail; and the effects of the valious fabrication steps, particularly of the final heat-treatment, are described in terms of metallography, resistance, density, x-ray diffraction, permeability, and chemical analysis. Properties of the composite matrices -m of $\mathrm{tm}$ portance in reactor use -- are presented and are correlated with fabrication conditions. The microstructure, carbide-cage structure, CTE, thermal conductivity, thermal-shock resistance (ZAP test), and thermal-stress resistance (peak power-density test) of the matrices are discussed.

\section{SUMMARY}

\section{A. Microstructure}

The best microstructure was obtained by heating the composite matrix substantially above the solidus temperature. Although heat-treatment temperatures were not known accurately, it is suspected that 15 to 258 of the carbide in these matrices was in liquid form for at least a short time during final heat-treatment. The microstructure had the following characteristics, as revealed by optical and electron microscopy: (1) the carbide was coarsened and coalesced into a continuous network, with the coalesced carbide having a crosssectional width ranging from 5 to $20 \mu \mathrm{m}$; (2) the large filler-flour particles were reorganized, i.e., polygonized, into blocky domains of graphite and contained angular voids; and (3) interparticle voids were often relatively equiaxed, with scalloped edges generally bounded by Type-I reorganized graphite. - [A common feature in the microstructures of $(U, \mathrm{Zr}) \mathrm{C}-\mathrm{C}$ (composites) heattreated to graphitizing temperatures is 
the presence of reorganized graphite, three forms of which have been recognized. Type I appears at relatively low graphitizing temperatures, principaliy at the expense of binder carbon and carbon black, and occurs largely as shells on carbide particles. Type II forms at higher temperatures, involves all the carbon in the matrix of the composite, and appears as large, blocky particles of extremely well-ordered material. It has often been described as proeutectic graphite. A third, polygonal, type develops from an internal reorganization of filler particles and appears as a progressive ordering of the filler-particle structure with no apparent change in size or shape of the particles. Further reorganization results in the formation of Type II graphite.]

\section{B. Carbide Network}

The best composite matrix had a strong interconnected three-dimensional network of coarse carbide. Scanning-electron microscopy of a piece of a fuel element from which all free carbon had been leached with 1-atm hydrogen at $\sim 1800 \mathrm{~K}$ revealed the network character of the carbide phase and confirmed the metallographic evidence that the carbide filaments were $\sim 5$ to $20 \mu \mathrm{m}$ in cross section. The 25-mm-long leached piece had its original shape and dimensions, and had a room-temperature axial crushing strength of $11.7 \mathrm{MPa}$.

\section{c. Coefficient of Thermal Expansion (CTE)}

Elements with 35 voli carbide and medium loadings of 298 to $382 \mathrm{~kg} / \mathrm{m}^{9}$ of 938 ${ }^{235} \mathrm{u}$, containing any of the high-CTE filler flours, did not have values of CTE above $6.8 \mathrm{\mu m} / \mathrm{m} \cdot \mathrm{K}$ after heat-treatment at > $2950 \mathrm{~K}$ (near or above the solidus temperatures). The matrices containing the high-CTE fillers had substantially higher values of CTE than matrices containing s-97 filler. For matrices containing high-CTE fillers: (1) the CTE increased with carbide content for comparable heat treatment; (2) the CTE of matrices containing $\mathrm{KX}-88$ filler was insensitive to heat-treatment temperature; (3) the CTE of matrices containing JM-15 filler, and perhaps Poco (L.F.) filler, decreased with increasing heat-treatment temperature; and (4) matrices made with highCTE filler were more isotropic than matrices made with s-97 filler, with the matrix containing POCO (L.F.) filler being isotropic.

Elements with 35 volo carbide and high loadings of $725 \mathrm{~kg} / \mathrm{m}^{3}$, containing $\mathrm{KX}-88$, JM-15, or GL-1076 filler, had CTE values of 7.0 to $7.2 \mu \mathrm{m} / \mathrm{m} \cdot \mathrm{K}$ when heat-treated at $\sim 2620 \mathrm{~K}$ for $6 \mathrm{~h}$ or subsequently at $\sim 2770 \mathrm{~K}$ for $2 \mathrm{~h}$ (versus a solidus temperature of $2820 \mathrm{k})$. These elements had values of CTE that were higher than those of any 35-volscarbide composite element made before. However, the $\mathrm{RX}-88$ matrix, the only one tested to date, had poor thermal-stress resistance reflecting a poor microstructure.

\section{Thermal Conductivity}

Composite matrices heated to temperature near or above the solidus temperature had room-temperature thermal conductivities ranging from 69 to $87 \mathrm{w} / \mathrm{m} \cdot \mathrm{R}$. These data were consistent with values predicted on the basis of Bruggeman's model for variable dispersions, unlike the lower values obtained previously on materials containing 5-97 filler that had been heat-treated far below the solidus temperatures. One composite matrix (35 voli carbide, $\mathrm{kX}-88$ flour, $382 \mathrm{~kg} / \mathrm{m}^{3}$ loading, $3010 \mathrm{k}$ solidus temperature) showed an increase in thermal conductivity from 71 to $87 \mathrm{~W} / \mathrm{m} \cdot \mathrm{K}$ when the nominal final heat-treatment temperature was increased from $\sim 3020$ to $3070 \mathrm{~K}$, giving the desired microstructure.

Some fuel-element sections had extremely high room-temperature thermal conductivities. The high values were associated with excessive melting at the surfaces of bores, which occurred in portions of 30-volf carbide elements in two final heattreatment runs. Subgtantial axial movement of the carbide took place in these elements. 
This movement can be explained only as due to a lowering of the carbide melting point by impurities in the argon sweep gas. The excessively melted porous region next to each bore near the middle of the element showed the presence of massive carbide and of large blocks of Type-II (proeutectic) graphite. Such material had a room-temperature thermal conductivity of $150 \mathrm{w} / \mathrm{m} \cdot \mathrm{R}$. Moreover, relatively nonporous regions from near the ends of the same element, in which highly coalesced carbide and very highly reorganized graphite was present, had thermal conductivities of $n 120 \mathrm{~W} / \mathrm{m} \cdot \mathrm{K}$. This indicates that usable composite matrices can be made with thermal conductivities > 100 $\mathrm{W} / \mathrm{m} \cdot \mathrm{K}$. The CTE of this excessively melted matrix was approximately the same as that of an unmelted matrix.

The room-temperature thermal conductivity of a composite matrix clearly is determined primarily by the thermal conductivity of the carbon phase. The contribution of the carbide network to the conductivity would be expected to be substantially less than the $\sim 25 \mathrm{w} / \mathrm{m} . \mathrm{K}$ for dense $\mathrm{zrC}$. The degree of reorganization or polygonization of the filler flour that occurs during heattreatment at temperatires near and above the solidus temperature of the composite matrix clearly is the important factor because the carbon blacks and the binder residue have earlier been converted to Type-I graphite. The reorganizea graphite in the composite element, if fully dense, should have a room-temperature conductivity $>100$ $w / m \cdot k$.

\section{E. Thermal Shock Resistance}

Elements that showed excessive melting near the middle of their length showed spectacularly high thermal-shock resistance at that location in most cases. There were indications, however, that the high thermalshock resistance may have been due to microstructural effects as well as to the exceptionally high thermal conductivity (i.e., $150 \mathrm{w} / \mathrm{m} \cdot \mathrm{K}$ for one matrix).
The general trend was that 30-volz-carbide materials were more resistant to thermal shock than 35-volf-carbide materials. No correlation with flour type was found. Within a given extrusion lot of elements that had medium loadings and did not show excessive melting, thermal-shock test results were essentially independent of final heattreatment temperature. Thus, for these elements, thermal conductivity did not appear to affect the thermal-shock test results. For elements with high uranium loading, thermal shock resistance increased with final heat-treatment temperature.

\section{F. Thermal Stress Resistance (Peak Power Density Test)}

The test results obtained on uncoated fuel elements demonstrated that 35-volscarbide composite matrices with thermalstress resistances greater than those required for elements in a nuclear propulsion reactor can be made by using high-CTE $\mathrm{kX}-88$ or JM-15 filler flour. The best of the $\mathrm{KX}-88$, 35-volo-carbide elements were almost as resistant to thermal stress as the best $30-$ voli-carbide matrix made previously with s-97 filler and were comparable to the GL-1074, 30-voli-carbide wANL element tested. The KX-88, 35-voli-carbide elements showed increasing thermal-stress resistance that correlated well with the degree to which the desired microstructure was approached and to which the thermal conductivity increased. Several $\mathrm{kx}-88,30$-vol-8-carbide elements showed very good thermal-stress resistance, i.e., could not be broken before the test was terminated due to carbon leaching, even though they were not heat-treated to the desired microstructure.

\section{G. Heat-Treatment conditions}

A summary of properties of composite elements as influenced by a slight change in heat-treatment conditions is given in Fig. B1. A change of $\sim 50 \mathrm{k}$ in heat-treatment temperature increased the thermal conductivity by $\sim 208$ and the thermal-stress resistance by $\sim 308$. 


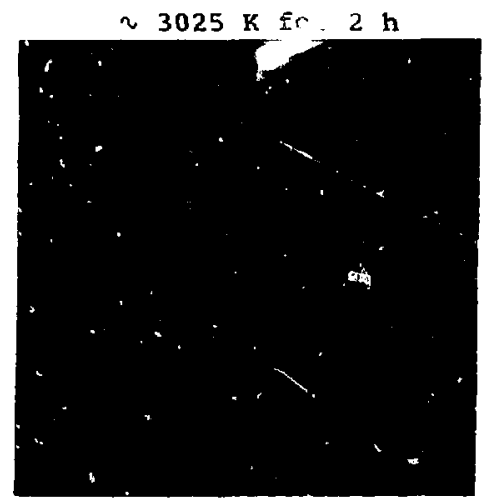

$\sim 3075 \mathrm{k}$ for $2 \mathrm{~h}$

(a)

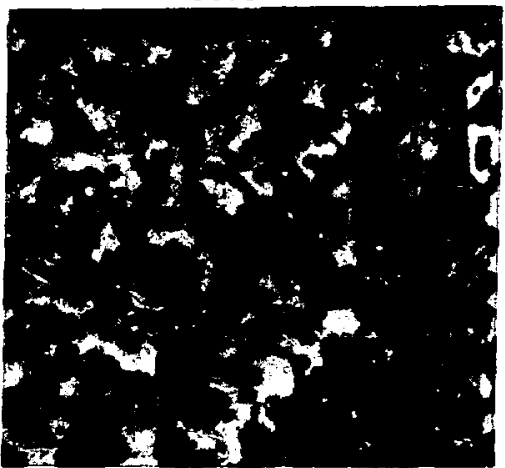

Thermal conductivity

71

$1 \leftarrow 100 \mathrm{sm} \rightarrow 1$

Thermal Expansion

(293-2300 K)

6.6

Power to Fractura

4400-5300

Compressive Strength

$\sim 110$

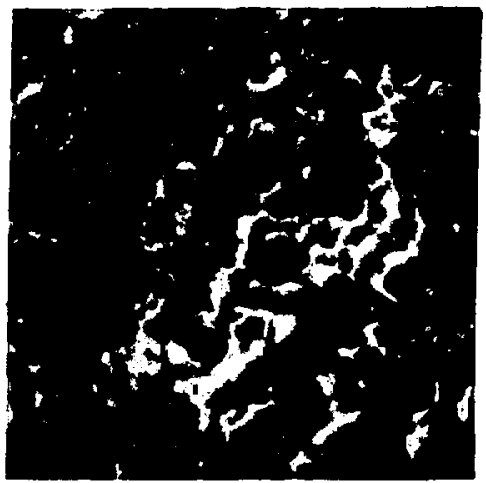

(b)

Compressive strength

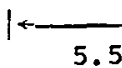
5.5

$87 \mathrm{~W} / \mathrm{m} \cdot \mathrm{K}$

Thermal Expansion

(293-2300 K)

--

$6.8 \mu \mathrm{m} / \mathrm{m} \cdot \mathrm{K}$ 5800-6600 MW/ $\mathrm{m}^{3}$ $\sim 110 \mathrm{MPa}$

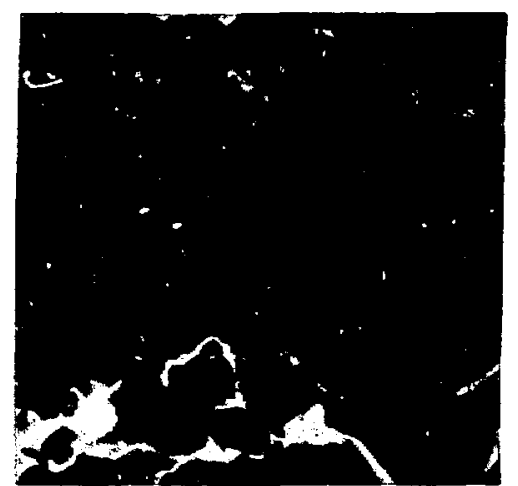

$$
\text { (a) }
$$

$\mu \mathrm{m}$

$11.7 \mathrm{MPa}$

$7.6 \mu \mathrm{m} / \mathrm{m} \cdot \mathrm{K}$

Fig. Bl. Effect of heat-treatment temperature on selected properties of a composite element. Material: $35-\operatorname{vol} 8(\mathrm{U}, \mathrm{Zr}) \mathrm{C}$ at $382 \mathrm{~kg} \mathrm{v} / \mathrm{m}^{3}$ loading; KX-88 graphite flour; solidus, $3010 \mathrm{~K}$. (a) microstructure; (b) carbide structure, carbon leached out.

\section{COMPOSITE MATRIX PREPARATION}

\section{A. Introduction}

The goal of the LASL composite fuelelement development program was to produce elements of acceptable thermal-stress resistance whose $\mathrm{ZrC}$ coatings will remain crack-free even after electrical corrosion or reactor testing.

A fuel-element matrix with high thermal conductivity will have, under reactor operating conditions, lower temperature gradients in the matrix and thus lower thermal stresses than a matrix with a low thermal conductivity. A strong three-dimensional interconnected network of carbide may be effective in hindering matrix crack propagation, may provide high mechanical strength and, very importantly, may leave a persistent structure should the matrix become subject to hydrogen attack through coating failure or element breakage in a reactor. The smaliest attainable CTE mismatch between the matrix and the zrc coating was desired, to minimize crack formation in the coating and defect corrosion during element use. 
Elements were submitted to improved heat-treatment in a vertical coating furnace modified for use up to $3100 \mathrm{~K}$. Attempts were made to increase the CTE of the niatrix by using high-expansion fillers and by increasing the carbide content to 35 vol8, the maximum carbide content assumed tolerable from thermal-stress considerations.

The NF-1 composite fuel-element experiment applied these methods toward improving the composite matrix. Some param eters of the experiment are shown in Table $B I$, namely, four types of filler flour, 30 and 35 voli carbide content, and medium and high uranium loading. Some elements from this experiment were fabricated to pruvide improved coated elements for use as elements in the NF-1 reactor.

Composite elements with very desirable properties had been made previously at LASI, i.e., elements made from s-97 flour with 30 voli carbide and $500 \mathrm{~kg} / \mathrm{m}^{3}$ loading. These elements gave good results in corrosion testing and in thermal-stress testing. Portions of the elements that gave good results in thermal-stress testing had a coarse matrix carbide structure, an unusually high degree of reorganization of the large filler-flour particles, and a thermal conductivity of $76 \mathrm{w} / \mathrm{m} \cdot \mathrm{K}$. The three-aimensionai interconnected character of the carbide structure from these elements had been demonstrated by scanning-electron-microscope (SEM) examination of pieces from which all the carbon had been leached with flowing hydrogen at $1 \mathrm{~atm}$ and $1870 \mathrm{~K}$ for more than $300 \mathrm{~h}$. The axial crushing strength of the 25-mm-long leached piece was $\approx 8.6 \mathrm{MPa}$. The highly reorganized larger filler-flour particles in these elements resembled, in some respects, proeutectic graphite found in composite samples known to have been heated to temperatures above the solidus temperatures. This overall type of carbide and filler-flour microstructure was taken as the target structure (see Fig. B2), and
TABLE BI

DESCRIPTION OF COMPOSITE EIEMENTS IN NF-1 EXPERIMENT

\begin{tabular}{|c|c|c|c|c|}
\hline $\begin{array}{l}\text { Graphite } \\
\text { Filler } \\
\text { Flour } \\
\end{array}$ & $\begin{array}{l}\text { Cerbide } \\
\text { Content, } \\
\text { yoli } \\
\end{array}$ & $\begin{array}{l}\text { U Loading, } \\
\mathrm{kg} / \mathrm{m}^{3}\end{array}$ & $\begin{array}{l}\text { Extrusion } \\
\text { Lot } \\
\text { No. } \\
\end{array}$ & $\begin{array}{c}\text { Units } \\
\text { In } \\
\text { NE-1 }\end{array}$ \\
\hline \multirow[t]{6}{*}{$k x-88$} & 30 & 435 & 52 & - \\
\hline & & 435 & 65 & - \\
\hline & & 324 & 61 & - \\
\hline & 35 & 382 & 62 & 4 \\
\hline & & 308 & 50 & 3 \\
\hline & & 298 & 60 & 1 \\
\hline \multirow[t]{2}{*}{$J M-15$} & 30 & 424 & 51 & 3 \\
\hline & 35 & 308 & 53 & 2 \\
\hline $\begin{array}{l}K X-88 / \\
J M-15^{a}\end{array}$ & 35 & 339 & 56 & 2 \\
\hline$G L-1076$ & 30 & 382 & 58 & 3 \\
\hline POCO $(L, F)^{b}$ & b 30 & 435 & 63 & - \\
\hline$x x-8 B$ & 35 & 725 & 54 & - \\
\hline$\pi / 15$ & 35 & 725 & 55 & - \\
\hline GL-1076 & 35 & 725 & 59 & - \\
\hline $\begin{array}{l}\text { GL-1074 } \\
\text { (WANL) }\end{array}$ & 30 & 440 & 8 & 5 \\
\hline
\end{tabular}

heat-treatment to temperatures above the solidus temperature was presumed to be necessary to attain this target structure.

The overall fabrication and evaluation sequence for composite fuel elements is shown in Fig. B3. The nondestructive tests (NDT) and the evaluation tests conducted were: PERM, permeability of matrix to gas flow; IPDE, resistance of matrix as measured by an incremental potential drop examination; MULE, mass-per-unit length examination by gamma-ray absorptometry; EC (1 and E) - Internal and external eddy current examination of matrix for flaws; GAMMA count examination for nondestructive assay of ${ }^{235} \mathrm{U}$; $\mathrm{RAD}, \mathrm{x}$-ray radiography examination for matrix flaws; HREC, high-resolution eddy current exanination for cracks in $\mathrm{ZrC}$ 


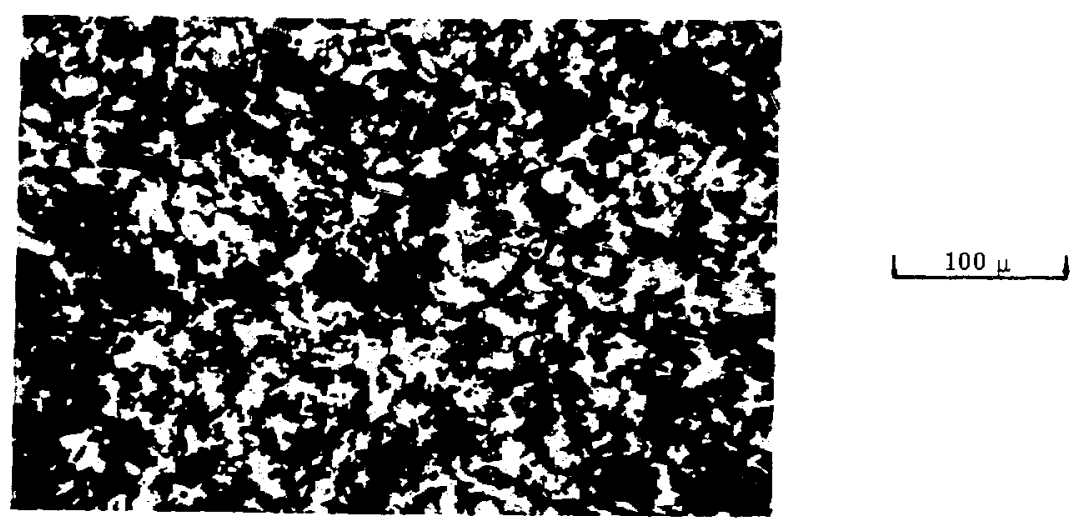

TARGET STRUCTURE

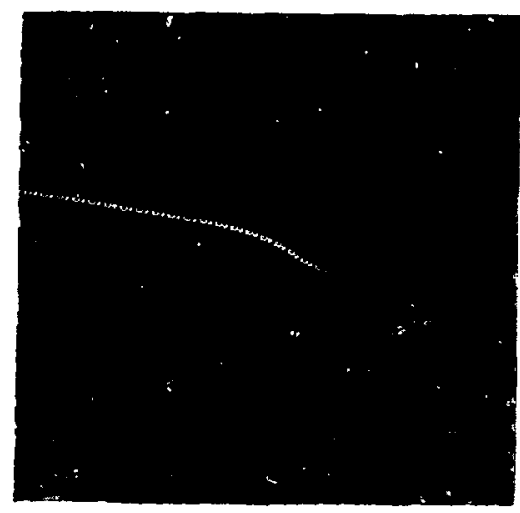

LOW-FIRE $2650 \mathrm{~K}$

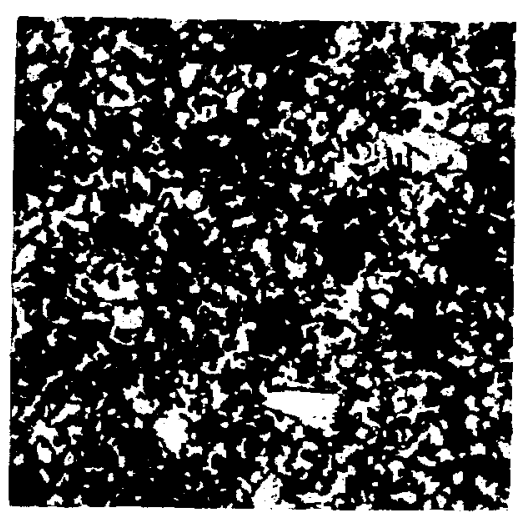

HIGH-FIRE $3025 \mathrm{~K}$

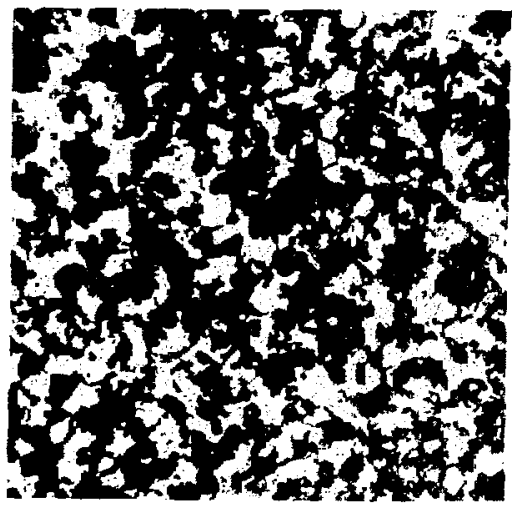

HIGH-FIRE $3075 \mathrm{~K}$

ELEMENTS FROM LOT $62\left(\mathrm{KX}-88,35 \mathrm{vOl}, 382 \mathrm{~kg} \mathrm{U} / \mathrm{cm}^{3}\right)$ (STATION 28)

Fig. B2. Microstructure of composite elements as a function of heat-treatment temperature. The gray areas are graphite, the white areas are carbide, and the black areas are void.

coatings: HOLE LOC., examination of a wafer for location of coolant channels; MET, metallographic examination of matrix and coating microstructure; CHEMISTRY, analysis for elemental composition; X-RAY DIFF., $x$-ray diffraction for composition of $(U, z r) C$ phase; LEACH, remove carbon from a sample by reaction with hot hydrogen and study carbide network; CTE, coefficient-of-thermal-expansion determination; ZAP, thermalshock test; THERMAL STRESS, determination of electrical power density required to produce matrix fracture; PHYSICAL PROP., determination of mechanical and thermal properties; and HOT GAS TEST, evaluation of resistance of coated element to reaction with flowing hot hydrogen gas.
The elements were made by an extrusion process from a mixture of powdered ingredients and a thermosetting binder. During the Low-Fire heat-treatment at temperatures up to $2600 \mathrm{~K}$, solid-solution $(\mathrm{U}, \mathrm{Zr}) \mathrm{C}$ carbide was formed in situ. The final High-Fire heat-treatment at temperatures of 2800 to $3100 \mathrm{~K}$ produced the structural changes in both the carbide and graphite phases.

\section{B. Materials and Extrusion}

The $\mathrm{ZrC}$ powder used in the manufacture of fuel elements was reactor-grade $<200$ ppm.Hf) and had a Fisher average particle size of $3.5 \mu \mathrm{m}$. A typical analysis was 88.3영 zirconium and 11.58 total carbon, 


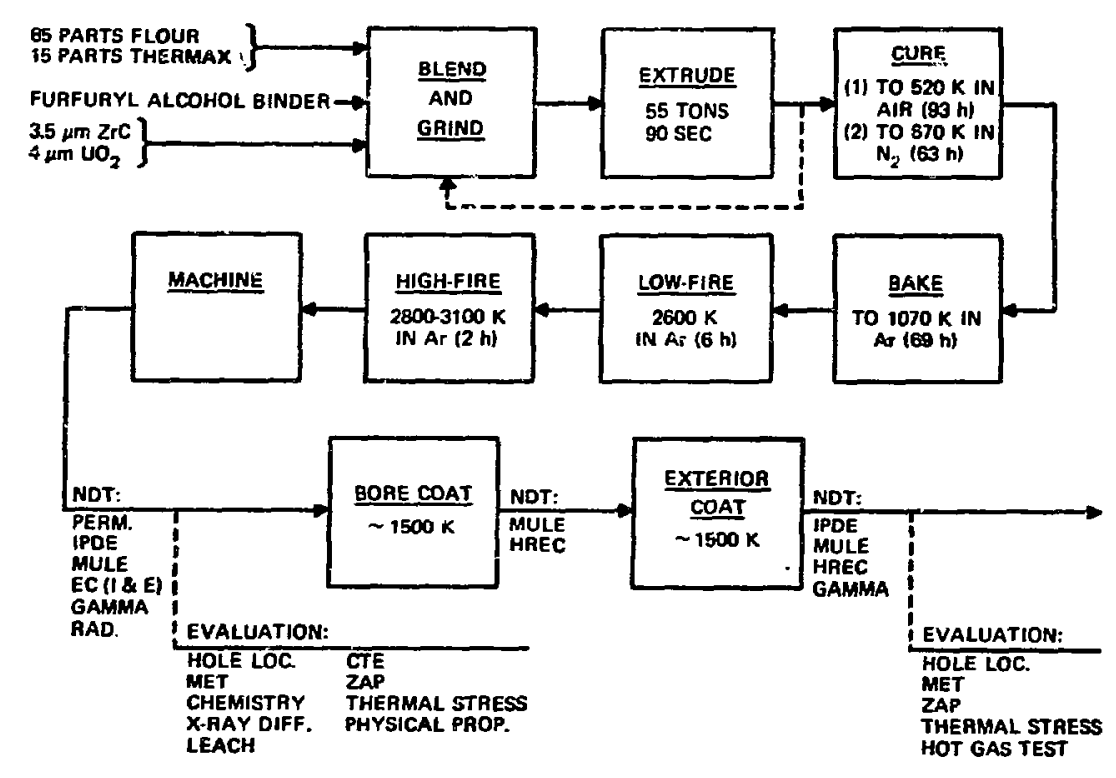

Fig. B3. Preparation and evaluation of composite fuel elements.

$\sim 0.28$ of which was free carbon. Impurities included $0.28 \mathrm{~N}_{2}, 0.28 \mathrm{O}_{2}$, and 90 ppria of sulfur. Metallic impurities were low, the major ones being 200 ppm of titanium, 150 Fim of tantalum, and $100 \mathrm{ppm}$ of iron. The carbide particles were of high density and relatively equiaxed.

The enriched $\mathrm{UO}_{2}$ powder used in the fuel-element extrusion $\mathrm{mix}$ was produced at LASL. The powder was -325 mesh and had a Fisher average particle size of $\sim 5 \mu \mathrm{m}$. The particles were dense and discrete. Total metallic impurities were limited to $500 \mathrm{ppm}$ with a maximum of 1 ppm of boron and $0.5 \mathrm{ppm}$ of cadmium.

The graphite filler flours used in this program had a particle-size distribution, as determined by sieve anulysis, of $28+200$ mesh, $88-200+270$ mesh, $208-270+325$ mesh, and $70 z-325$ mesh. The flours contained $\sim 100$ pem of ash and had a Fisher average particle size of $4.75 \mu \mathrm{m}$.

The filler flours used in the NF-1 experiment are to be contrasted w.th s-97 graphite flour, which was a filler material that had been previously used extensively at IASL to fabricate the first composite elements. The s-97 flour consists of dense, relatively acicular particles which, upon etching, show highly developed lamellar structures and large, elongated, optical domains. Because of their shapes, these particles tend to assume a definite preferred orientation during extrusion, yielding anisotropic graphites which, in the extrusion direction, have low CTE and low electrical resistivity. In general, the thermal conductivity of graphites is inversely proportional to electrical reslstivity.

The POCO (L.F.) filler after heating to high temperature consists of particles which, upon suitable etching, were shown to be made up of very fine, nearly equiaxed, randomly oriented optical domains, within each of which the lamellar graphite structure is wEll developed. Because of the sizes and shapes of these domains, grinding the material to normal particle-size distributions produces principally blocky particles, each of which contains enough randomly oriented domains so that it is essentially isotropic. This randomness also results in high CTE and high electrical resistivity. Typically, therefore, a graphite made from a poco filler is nearly isotropic and has high CTE 


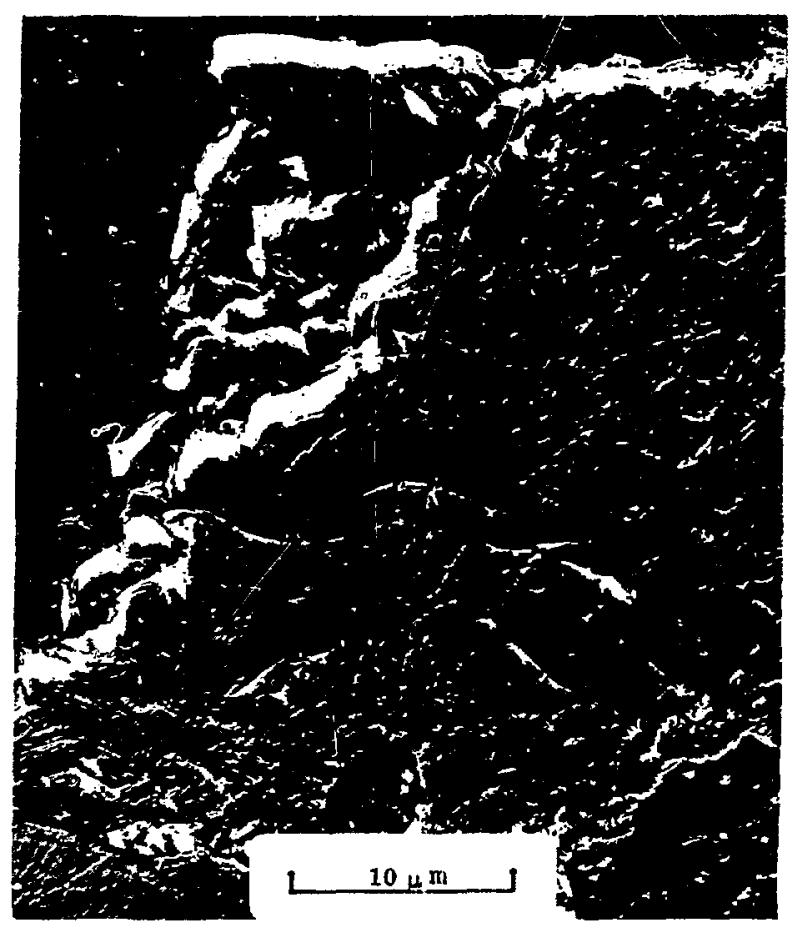

$\mathrm{KX}-88$

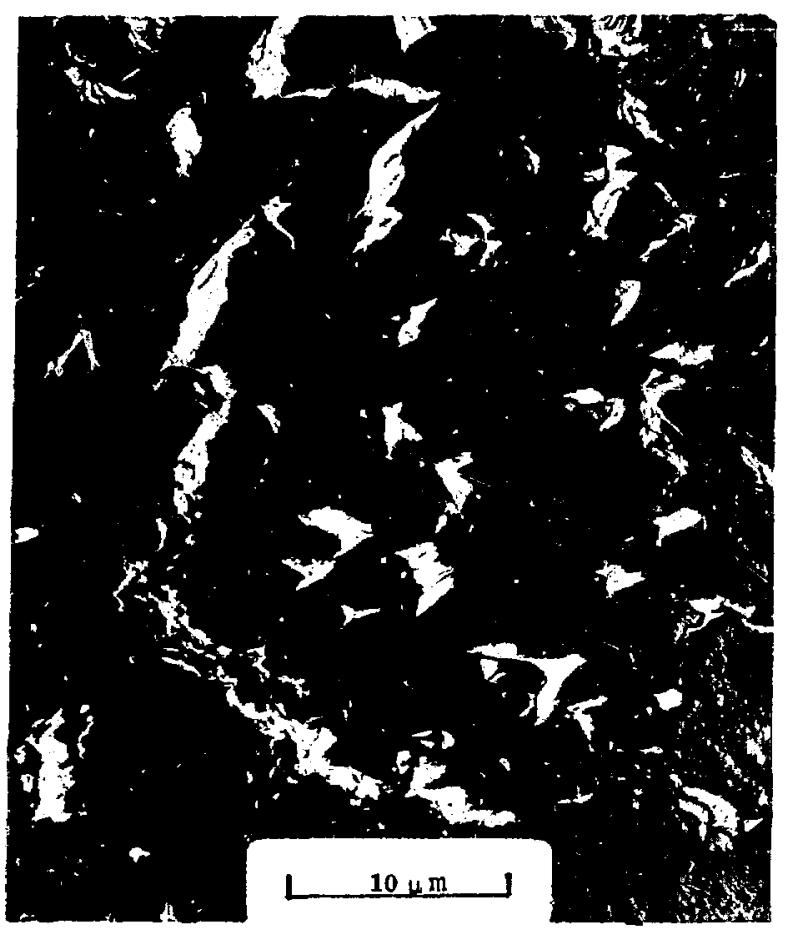

POCO

Fig. B4. Electron micrographs of graphite filler flours: KX-88 flour graphitized during fatrication by vendor and POCO (Low-Fire) after heating to $2870 \mathrm{~K}$ during fuelelement manufacture.

and high electrical resistivity. POCO fillers also contain a distinctive pattern of fine, quite uniformIy distributed voids, which distinguish it from otherwise similar fillers such as Robinson filler. * Figure B4 shows an electron micrograph of a POCO flour particle that had been heated to $n$ $2870 \mathrm{~K}$. One particle is shown in the field of view. Note the fine, nearly equiaxed, randomly oriented optical domains, within which the lamellar graphite structure is well developed.

\footnotetext{
* Robinson filler is made from an experimental airblown coke which was produced by Union Carbide Corp. in a pllot-scale operation. After grinding, the coke consists of dense, blocky particles with extremely fine, random internal structures with an exceptionally high CTE. The Robinson fillers used at LASL have in general been sezondary graphite flours, produced by grinding graphites made from Robinson coke and a pitch binder. These fillers contain graphitized binder carbon as well as graphitized coke filler, but have a CTE approaching that of the graphitized coke itself.
}

The $K X-88$ and JM-15 fiilers are very much alike, and would be expected to produce very similar graphites. Both consist principally of quite dense, nearly equiaxed particles which, when etched, are shown to be made of small, elongated optical domains in a variety of sizes and with some order in their arrangements. However, both also contain a significant proportion of acicular particles having highly ordered internal structures, which would be expected to orient during extrusion and result in some degree of anisotropy in the finished graphite. Because they contain particles resembling the POCO filler and also particles resembling the s-97 filler, the $\mathrm{kx}-88$ and JM-15 flours would be expected to produce graphite CTEs and resistivities intermediate between those of matrices made from POCO and $5-97$ flours. Both flours ( $\mathrm{KX}-88$ and JM-15) had desirable particle-size distributions and would be expected to yield 
dense graphites with good mechanical properties. An electron micrograph of a $\mathrm{kx}-88$ particle is shown in Fig. B4. A relatively large optical domain is shown in the lower portion of the micrograph, whereas the upperright area contains many small randomly oriented domains. The $\mathrm{kX}-88$ particle was heated during manifacture to a high temperature and shows the structure at the start of the composite fuel-element fabrication process.

GL-1076 filler consists generally of equiaxed particles containing two types of internal structure, one of which is porous and resembles a POCO filler while the other is dense and resembles the Robinson filler. The particle-size distribution of the GL-1076 tends to be bimodal, with many relatively large particles and many very small ones, but few in the intermediate size ranges. Unless an addition (e.g., of carbide) is made of particles which happen to fill this particle-size gap, the GL-1076 filler would be expected to yield a graphite of rather low density with correspondingly low mechanical properties. As is usually true, the very fine particles tend to be somewhat acicular and ordered in internal structure. A graphite matrix made from GL-1076 would therefore be expected to approach the properties of one made from a poco filler. Thermax carbon black, from Thermatomic Carbon Co., was used because it acted as an extrusion lubricant and aided in increasing the carbon density of the fuel elements. varcum 8251 thermosetting resin, from Varcum Chemical Div. of Reichhold Chemicals, Inc., was used as the binder. Varcum is a partially polymerized furfuryl alcohol with a room-temperature viscosity of $\sim 300 \mathrm{cP}$. Maleic anhydride was used to catalyze the polymerization (4 $\mathrm{g}$ of catalyst to $100 \mathrm{~cm}^{3}$ of binder).

Calculational procedures were established which allowed a specific volume percent total carbide and uranium loading to be obtained in the finished fuel element.
A typical extrusion mixture consisted of: 26.26 wto graphite flour plus Thermax mixture, $51.62 \mathrm{wto} \mathrm{zrC}$ powder, $7.46 \mathrm{wto} \mathrm{UO}_{2}$ powder, and 14.67 wto varcum binder. The weight ratio of graphite flour vs Thermax in the mixture was usually $85: 15$. Figures $B 5$ and $B 6$ show the extrusion dies used and the air-vein fixture that received the extruded element.

The first of a series of heat treatments required $93 \mathrm{~h}$ to reach $520 \mathrm{~K}$ (electrically heated circulating-air ovens were used), during which the furfuryl alcohol underwent polymerization. The second heat treatment, using a $\mathrm{N}_{2}$ atmosphere, required $63 \mathrm{~h}$ to heat the elements from 470 to $720 \mathrm{~K}$. The third heat treatment (called the baking cycle) consisted of heating to $1100 \mathrm{~K}$ during a 39-h cycle at a pressure of 10 Torr or less using an argon flush.

\section{Baked Elements}

Differences among the various filler flours show up strikingly in the electrical resistances of baked composite elements, as indicated in Table BII. In the baked condition there is no interconnected carbide network and the resistances of the elements are high, with resistance of the fillerflour particles and binder residue apparently playing the major role in determining the electrical properties of the continuous carbon matrix. These resistance differences have largely disappeared after the elements have been low-fired at $\sim 2620 \mathrm{~K}$ for $\sim 6 \mathrm{~h}$, with only the Poco elements apparently showing slightly higher resistances. However, a portion of this difference may be due to fine matrix cracks that can be seen metallographically in the low-fired poco elements. These data indicate that in lowfired elements, in which the filler-flour particles are unchanged, the electrical conduction must be mainiy through a connected carbide network and through Type-I graphite that is next to the carbide particles. The resistance differences have disappeared 


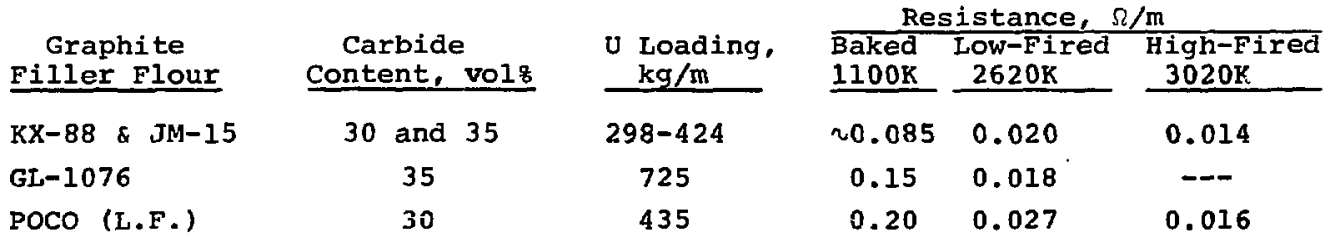

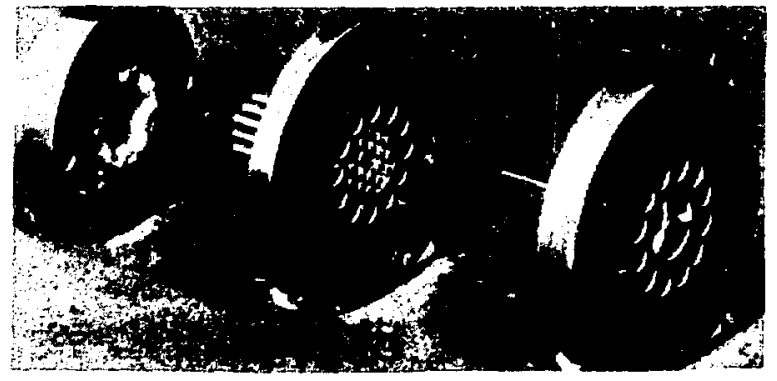

Fig. B5. Extrusion tooling for 19-hole hexagonal (U, Zr)C-graphite (composite) fuel elements.

completely after the elements have been highfired at $3020 \mathrm{~K}$ for $2 \mathrm{~h}$, even for the badly cracked poco elements. This similarity in resistance may be attributed to coalescence of the interconnected carbide network and possibly to reorganization of the small, but not the large, filler-flour particles. The room-temperature resistivity of stoichiometric $\mathrm{ZrC}$ is 20 to $50 \times 10^{-6} \Omega \mathrm{cm}$; of polycrystalline fabricated graphite, 500 to $1000 \times 10^{-6} \Omega \mathrm{cm}$; and of single-crystalline graphite in the basal plane direction, $\sim 50 \times 10^{-6} \Omega \mathrm{cm}$.

\section{Low-Fired Elements}

Figure B7 shows photomicrographs of matrices from four low-fired elements with medium loadings that were evaluated primarily because of interest in comparing their thermal expansion properties with those of corresponding high-fired elements. The white areas are carbide, the gray areas are graphite, and the black areas are void.

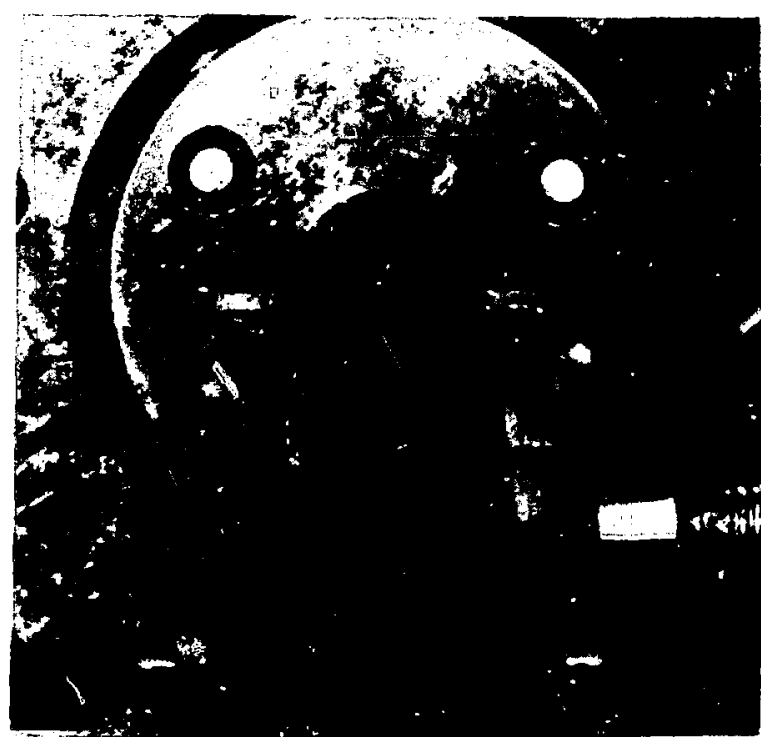

Fig. B6. Extrusion of 19-hole (U, Zr)Cgraphite (composite) fuel element onto air-vein fixture.

The elements containing $\mathrm{KX}-88$ or JM-15 filler flours showed most clearly that the flour particles were surrounded, but not penetrated, by carbide at this stage. Optical and electron microscopy revealed the presence of some mype-I graphite on the surfaces of carbide particles. This type of graphite presumably results from ejection of carbon when $\mathrm{UC}_{2}$ from carburization of $\mathrm{UO}_{2}$ reacts with $\mathrm{ZrC}$ to form $(\mathrm{U}, \mathrm{Zr}) \mathrm{C}$ solidsolution, as well as from graphitization of carbon black and binder residue in the presence of carbide.

Table BIII gives $x$-ray diffraction data for low-fired elements with loadings ranging from 0.056 to 0.137 uranium atom 


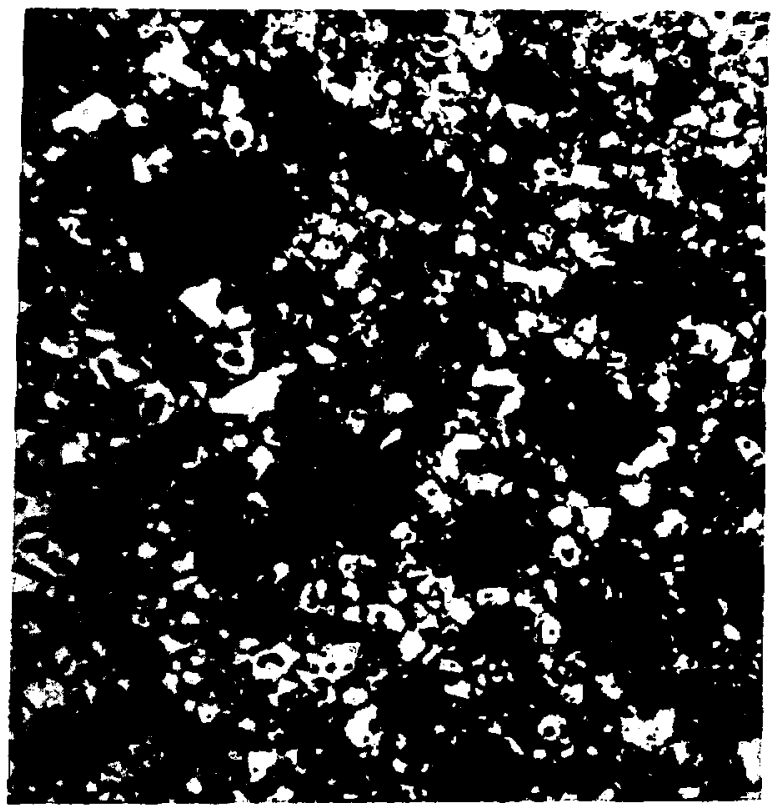

Lot $50\left(\mathrm{KX}-88,35 \mathrm{vol}, 308 \mathrm{~kg} \mathrm{U} / \mathrm{m}^{3}\right)$

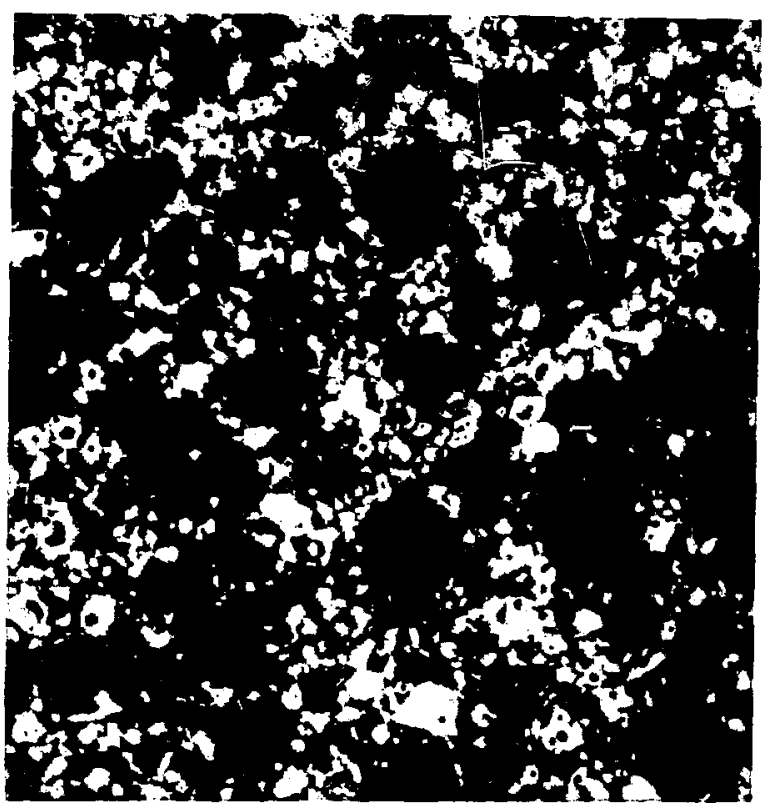

Lot $53\left(\mathrm{JM}-15,35 \mathrm{vol}\right.$, $\left.308 \mathrm{~kg} \mathrm{U} / \mathrm{m}^{3}\right)$ Low-fire Run 7 $100 \mu \mathrm{m}$

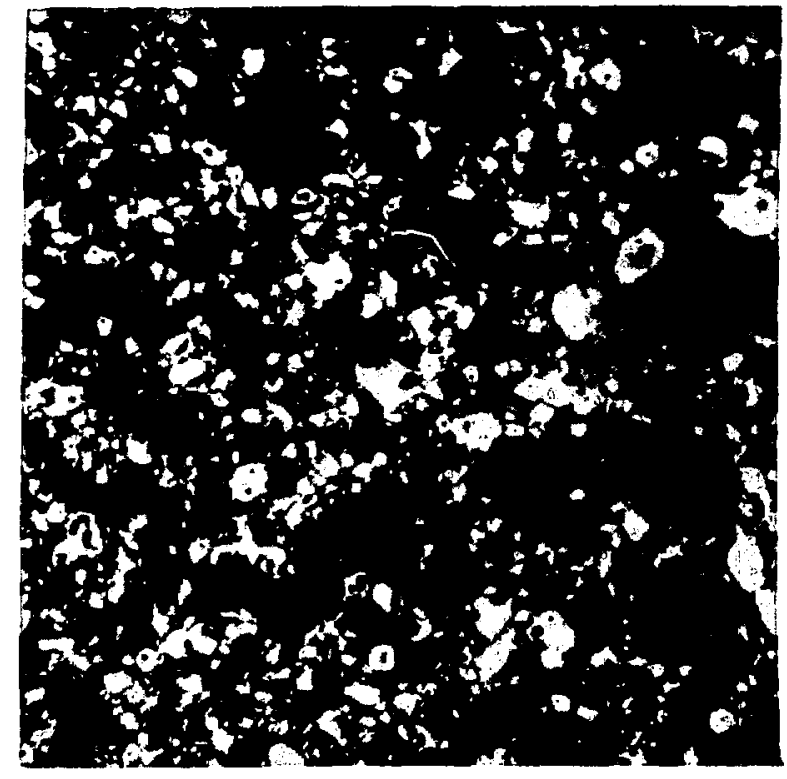

Lot $62\left(\mathrm{KX}-88,35 \mathrm{vol}, 382 \mathrm{~kg} \mathrm{U} / \mathrm{m}^{3}\right)$ Low-fire Run 7

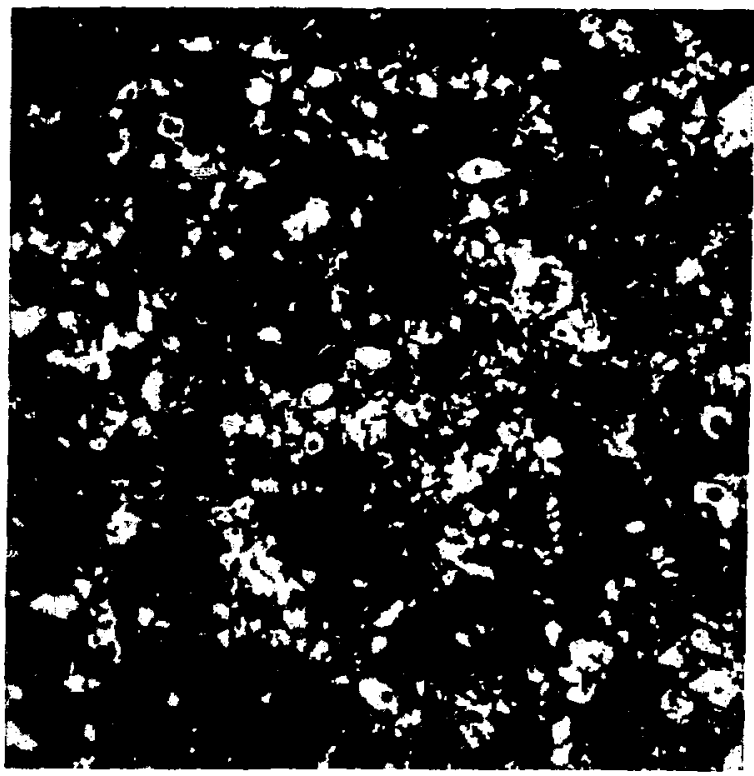

Lot 6.3 (POCO-L.F., 30 volis, $435 \mathrm{~kg} \mathrm{U} / \mathrm{m}^{3}$ ) Low-fire Run 7

Fig. B7. Photomicrographs of low-fired elements ( $2620 \mathrm{~K}$ for 6 h), sampled at station 710 . 
TABLE BIII

X-RAY DIFFRACTION DATA ON LOW-FIRED ELEMIENTS FROM NF- 1 EXPERIMENT ${ }^{a}$

\begin{tabular}{|c|c|c|c|c|c|c|c|}
\hline $\begin{array}{l}\text { Low-Fire } \\
\text { No. }\end{array}$ & $\begin{array}{c}\text { Element } \\
\text { Lot Load No. }\end{array}$ & $\begin{array}{l}\text { Filler } \\
\text { Flour } \\
\end{array}$ & $\begin{array}{l}\text { Carbide } \\
\text { Content, } \\
\text { volis } \\
\end{array}$ & $\begin{array}{l}\text { Atom Ratio } \\
\mathrm{u} /(\text { ZrtU }) \\
\text { by Chean. }\end{array}$ & $\begin{array}{c}\text { Lattice }^{\mathbf{b}} \\
\text { Paraneter }\left(\mathrm{a}_{0}\right), \\
\end{array}$ & $\begin{array}{l}\text { Calculated } \\
\text { Composition }\end{array}$ & Cormments $^{e}$ \\
\hline 7 & $50-308-93452$ & $\mathrm{kX}-\mathrm{Bg}$ & 35 & 0.057 & $\begin{array}{l}4.7303(14)^{d} \\
4.7153(2)\end{array}$ & $\begin{array}{l}\mathrm{v}_{0.112^{\mathrm{Zr}} 0.888^{\mathrm{C}}} \\
\mathrm{v}_{0.059^{\mathrm{Zr}} 0.941^{c}}\end{array}$ & $\begin{array}{l}\text { Major phase } \\
\text { Minor phase - } \\
\text { somewhat diffuse }\end{array}$ \\
\hline 11 & $53-308-93514$ & $\mathrm{MM}-15$ & 35 & 0.056 & $\begin{array}{l}4.7162(7) \\
4.6952(6)\end{array}$ & $\begin{array}{l}\mathrm{v}_{0.062^{\mathrm{Zr}}} 0.938^{\mathrm{C}} \\
\mathrm{ZrC}\end{array}$ & $\begin{array}{l}\text { Major phase } \\
\text { Minor phase }\end{array}$ \\
\hline 7 & $62-382-93701$ & $\mathbf{k x - 8 8}$ & 35 & 0.070 & $4.7182(2)$ & ${ }_{0.069^{\mathrm{Zx}}}^{\mathrm{J}_{0.931}}{ }^{\mathrm{c}}$ & $\begin{array}{l}\text { Single phase - } \\
\text { well resolved } \\
\text { high angle doublets }\end{array}$ \\
\hline 7 & $63-435-93728$ & $\begin{array}{l}\text { POCO } \\
\text { (L.F.) }\end{array}$ & 30 & 0.093 & $4.7257(4)$ & $\mathrm{v}_{0.096^{\mathrm{Zx}} 0.904^{\mathrm{C}}}$ & $\begin{array}{l}\text { Single phase - } \\
\text { doublets } \\
\text { slightly diffuse }\end{array}$ \\
\hline 8 & 54- 725-93529 & $1 \times X-88$ & 35 & 0.137 & $4.7369(3)$ & $\mathrm{v}_{0.135^{\mathrm{Zx}} 0.865^{\mathrm{C}}}$ & $\begin{array}{l}\text { Single phase - } \\
\text { doublets } \\
\text { well resolved }\end{array}$ \\
\hline 8 & $55-725-93572$ & JM-15 & 35 & 0.137 & $4.7363(2)$ & $\mathrm{d}_{0.133^{\mathrm{Zr}} 0.867^{\mathrm{C}}}$ & $\begin{array}{l}\text { Single phase - } \\
\text { doublets } \\
\text { well resolved }\end{array}$ \\
\hline 8 & 59- 725-93631 & GL-1076 & 35 & 0.137 & $4.7361(2)$ & $\mathrm{u}_{0.133^{\mathrm{Zr}} 0.867^{\mathrm{C}}}$ & $\begin{array}{l}\text { Single phase - } \\
\text { sharp, well } \\
\text { resolved doublets }\end{array}$ \\
\hline
\end{tabular}

ratio, metal basis. All the elements with uranium atom ratios from 0.07 to 0.137 had single-phase solid solution present and the doublets were sharp and well resolved, indicating that there was little gradation in solid-solution composition. These results suggest that a heat-treatiment for $6 \mathrm{~h}$ at $\sim 2620 \mathrm{~K}$ was sufficient to bring about the homogenization for these loadings. However, the $x$-ray diffraction data for the two elements with the lower uranium atom ratio of $\sim 0.056$ indicated that homogenization had not occurred. Perhaps a slightly higher temperature of heat-treatment is required for homogenization of the lower loadings.

The IPDE (incremental potential drop evaluation) plots of electrical resistance versus station were almost invariably quite flat for the low-fired elements. This indicates that the fabrication process to this stage probably has produced elements of relatively uniform properties along the full length of the element.

\section{E. High-Fired Elements}

\section{General}

A pseudobinary phase diagram for 35-vol8-carbide composite based on recent LASL data is shown in Fig. 3 of the main body of this report. The atom-percent uranium value on a metal basis is shown above the diagram. For a given carbide content, the solidus temperature (temperature at which liquid first appears on heating) drops sharply with uranium loading. The solidus temperature increases with increasing carbide content for a given urarium 
loading. Gaseous impurities in the heattreatment-furnace sweep gases, such as oxygen or water, can lower the effective solidus temperature. For the elements used in the NF-1 experiment, solidus temperatures ranged from 2820 to $3040 \mathrm{~K}$.

Elements that had been previously lowfired at $\sim 2620 \mathrm{~K}$ for $\sim 6 \mathrm{~h}$ were high-fired for $2 \mathrm{~h}$ at temperatures designed to be above the solidus temperatures of the elements in the high-fire batch, in attempts to form the coarse interconnected carbide network and the reorganized large filler-flour particles of the target structure. Obtaining the desired structure in elements in a given run proved to be very difficult, because of the sensitivity of the process to temperature, uncertainties in temperature measurement, and difficulties in controlling temperatures in the furnace as a function of time and position of the elements in the furnace. Nevertheless, some very definitive correlations between matrix structures and properties were obtained.

High-firing and low-firing of the elements was done in a vertical coating furnace modified for this purpose. The graphite fixture to hold the elements was a 30cm-0.d. by 13-cm-i.d. by 1.57-m long cylindrical annulus with an outer ring of 18 holes and an offset inner ring of 18 holes. The fixture was heated by an inductively heated graphite susceptor. Three banks of induction coils that can be controlled independently were used to control axial uniformity of temperature. The elements were loaded in the fixture so that the G-end* was up. The elements were swept from top to bottom with high-purity argon that flows through the fixture independently of the argon used to flush the furnace shell. The fixture was maintained at a positive pressure relative to the furnace shell. The

*The G-end of an element refers to low station numbers while the H-end refers to high station numbers. furnace has five sight ports (SP) in line on the side, through which the outside surface of the susceptor can be observed at positions that correspond from top to bottom to the following stations relative to the final element: -114 (SP2), 254 (SP3), 622 (SP4), 911 (SP5), and 1359 (SP6). The furnace was calibrated periodically by comparing temperatures observed through the sight ports with temperatures measured (through a viewing port in the furnace lid) on stepped graphite elements placed in four adjacent holes in the fixture. The calibration elements were plazed at the back of the fixture, opposite the sight ports, i.e., at the hottest part. The calibration steps were arranged to be at levels corresponding to the sight ports.

The calibration data for each sight port were best correlated by the expression $\mathrm{T}_{\mathrm{a}}=\mathrm{A}+\mathrm{BT}_{\mathrm{O}}$, where $\mathrm{T}_{\mathbf{a}}$ is the true temperature within the fixture and $T_{0}$ is the observed temperature through the sight port. Based on several calibration runs, the 2- $\sigma$ variation of $T_{a}$ corresponding to $T_{0}$ was $\pm 60 \mathrm{~K}$ for $\mathrm{SP} 2 ; \pm 50 \mathrm{~K}$ for SP3; and $\pm 40 \mathrm{~K}$ each for SPs 4, 5, and 6. These uncertainties in temperature were too large to guarantee that the target structure would be obtained in each high-fire run.

Following high-firing, the flats of all elements were machined to dimension, and the machined elements were subjected to nondestructive testing (NDT) as outlined in Fig. B3. Then two elements from each extrusion lot in a given high-fire batch were selected to be cut up into a variety of evaluation samples.

Seven high-fire runs were made for the NF-1 experiment. The runs are described in Table BIV, which gives solidus temperatures for the elements as well as the maximum temperature $\left(\mathrm{T}_{\mathrm{a}}\right.$ ) reported for each sight port in each run. The tenperature control during a given high-fire run did not ensure that all stations of the fuel-element fixture reached the naximum temperature at the same time, 


\begin{tabular}{|c|c|c|c|c|c|c|c|c|c|c|}
\hline \multirow[b]{2}{*}{$\begin{array}{l}\text { High-Fire } \\
\text { No. } \\
\end{array}$} & \multirow[b]{2}{*}{$\begin{array}{l}\text { Lot } \\
\text { No. }\end{array}$} & \multirow[b]{2}{*}{$\begin{array}{l}\text { Filler } \\
\text { Flour }\end{array}$} & \multirow{2}{*}{$\begin{array}{l}\text { Carbide } \\
\text { Content, } \\
\text { voli } \\
\end{array}$} & \multirow[b]{2}{*}{$\begin{array}{l}\text { U, Loading, } \\
\mathrm{kg} / \mathrm{m}^{3} \\
\end{array}$} & \multirow[b]{2}{*}{$\begin{array}{l}\text { Solidus } \\
\text { Temp, K }\end{array}$} & \multicolumn{5}{|c|}{ Reported Maximum Temp. $\left(T_{a}\right), K$} \\
\hline & & & & & & $\begin{array}{r}\text { SP } 2 \\
-114 . \underline{m} \\
\end{array}$ & $\begin{array}{c}\text { SP } 3 \\
254: \operatorname{mand}\end{array}$ & $\begin{array}{r}\text { SP } 4 \\
622=0\end{array}$ & $\begin{array}{r}\text { SP } 5 \\
991 \cdot \operatorname{man}\end{array}$ & $\begin{array}{l}\text { SP } 6 \\
1359 \mathrm{~mm}^{\mathrm{a}}\end{array}$ \\
\hline 1 & $\begin{array}{l}51 \\
53 \\
56 \\
58\end{array}$ & $\begin{array}{l}J M-15 \\
J M-15 \\
K X-8 B / J M-15 \\
G L-1076\end{array}$ & $\begin{array}{l}30 \\
35 \\
35 \\
30\end{array}$ & $\begin{array}{l}424 \\
308 \\
339 \\
382\end{array}$ & $\begin{array}{l}2960 \\
3035 \\
3025 \\
2990\end{array}$ & 2910 & 2980 & 3020 & 3020 & 3040 \\
\hline 2 & $\begin{array}{l}50 \\
60 \\
62\end{array}$ & $\begin{array}{l}K X-8 B \\
K X-88 \\
K X-88\end{array}$ & $\begin{array}{l}35 \\
35 \\
35\end{array}$ & $\begin{array}{l}308 \\
298 \\
382\end{array}$ & $\begin{array}{l}3035 \\
3040 \\
3005\end{array}$ & 2950 & 3030 & 3075 & 3045 & 3070 \\
\hline 3 & $\begin{array}{l}52 \\
61\end{array}$ & $\begin{array}{l}1 X X-88 \\
K X-88\end{array}$ & $\begin{array}{l}30 \\
30\end{array}$ & $\begin{array}{l}435 \\
343\end{array}$ & $\begin{array}{l}2955 \\
3005\end{array}$ & 3020 & 3075 & 3025 & 3020 & 3015 \\
\hline 4 & $\begin{array}{l}62 \\
63\end{array}$ & $\begin{array}{l}\text { KX-88 } \\
\text { POCO (L.F.) }\end{array}$ & $\begin{array}{l}35 \\
30\end{array}$ & $\begin{array}{l}382 \\
435\end{array}$ & $\begin{array}{l}3005 \\
2955\end{array}$ & 2975 & 3025 & 3025 & 3020 & 3015 \\
\hline 5 & $\begin{array}{l}53 \\
52 \\
58 \\
63\end{array}$ & $\begin{array}{l}J M-15 \\
\mathrm{KX}-88 \\
\mathrm{GL}-1076 \\
\text { POCO (L.F.) }\end{array}$ & $\begin{array}{l}30 \\
30 \\
30 \\
30\end{array}$ & $\begin{array}{l}424 \\
435 \\
382 \\
435\end{array}$ & $\begin{array}{l}2960 \\
2955 \\
2990 \\
2955\end{array}$ & 3010 & 3070 & 3040 & 3030 & 3020 \\
\hline 6 & $\begin{array}{l}65 \\
66\end{array}$ & $\begin{array}{l}\mathrm{KX}-88 \\
\mathrm{KX}-88\end{array}$ & $\begin{array}{l}30 \\
30\end{array}$ & $\begin{array}{l}435 \\
343\end{array}$ & $\begin{array}{l}2955 \\
3005\end{array}$ & 2950 & 2920 & 2965 & $-\infty$ & 2945 \\
\hline 7 & $\begin{array}{l}54 \\
55 \\
59\end{array}$ & $\begin{array}{l}K X-88 \\
J M-15 \\
G L-1076\end{array}$ & $\begin{array}{l}35 \\
35 \\
35\end{array}$ & $\begin{array}{l}725 \\
725 \\
725\end{array}$ & $\begin{array}{l}2820 \\
2820 \\
2820\end{array}$ & 2695 & 2820 & 2790 & 2745 & 2795 \\
\hline
\end{tabular}

\footnotetext{
$a_{S P}=$ sight port; positions are relative to flnal 1320 -ren-long element.
}

and the time at maximum temperature varied. Runs 3 and 5 resulted in excessive melting around the bores in portions of all elements.

\section{Metallography}

Metallographic examination of microstructures reveals the effects of heattreatment. Microstructure changes that occur on heat-treatment at temperatures just below the solidus show coalescence of the carbide cross section ( 3 to $10 \mu \mathrm{m}$ ) and formation of Type-I graphite close to the carbide surfaces. At temperatures substantially above the solidus where perhaps 15 to 258 of the carbide is liquid, the carbide is coalesced into areas of 10 to $20 \mu \mathrm{m}$ cross section, the smaller filler particles are approaching a Type-II graphite structure, and the larger filler particles are only slightly changed. However, at yet higher heat-treatment temperatures, massive carbide particles are found and all the graphite is in the form of large blocks of Type-II graphite.
Figures B8 a:2d B9 show photomicrographs of metallographic sections from an element of one of the lots in each of four runs that did not result in excessive melting.

In High-Fire Run 1 the coarseness of the carbide increased toward the higher stations (H-end), which is consistent with the reported maximum temperatures. This is illustrated in Fig. $B 8$ by an element from Lot 51. However, the coarseness of carbide of the target structure, shown in Fig. B2, was not attained and there was little, if any, reorganization of the large fillerflour particles at the H-end, despite the fact that Lot 51 had the lowest solidus temperature of the lots in High-Fire Run 1. The microstructures of the other lots in High-Fire Run 1 were little, if any, different from those of the Lot 51 elements.

Metallography of the Lot-62 elements from High-Fire Run 2 (see Fig. B8) indicated attainment of the target structure at all 

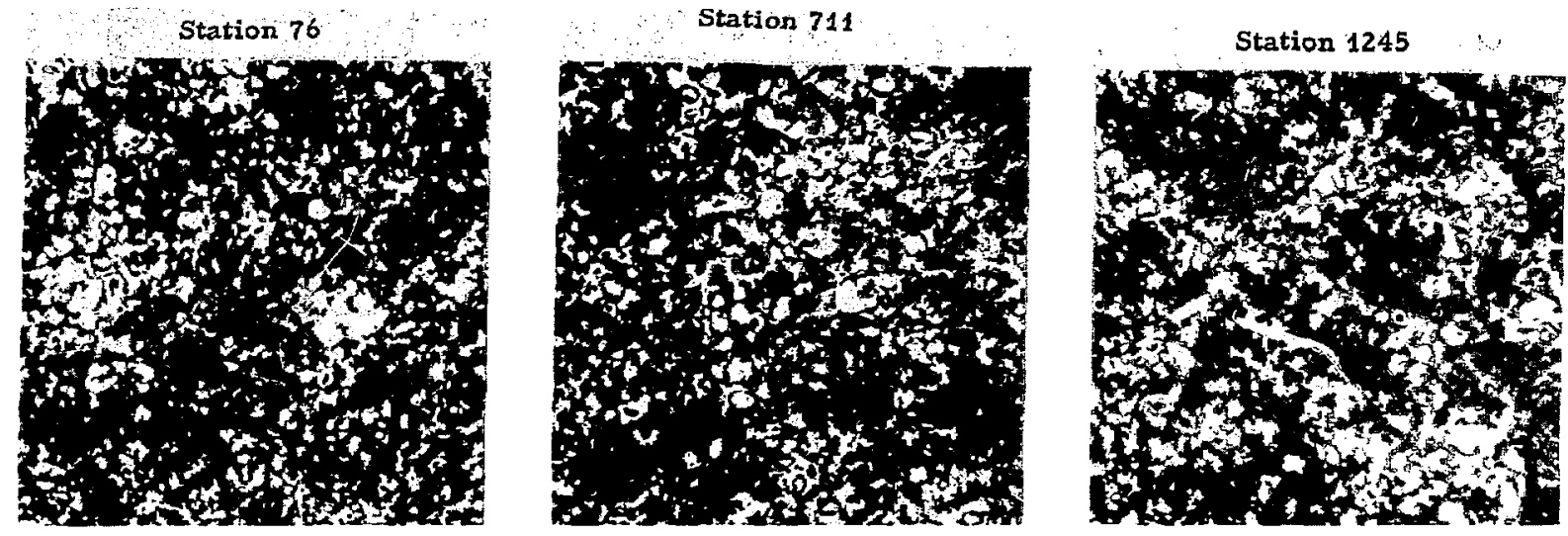

(a)
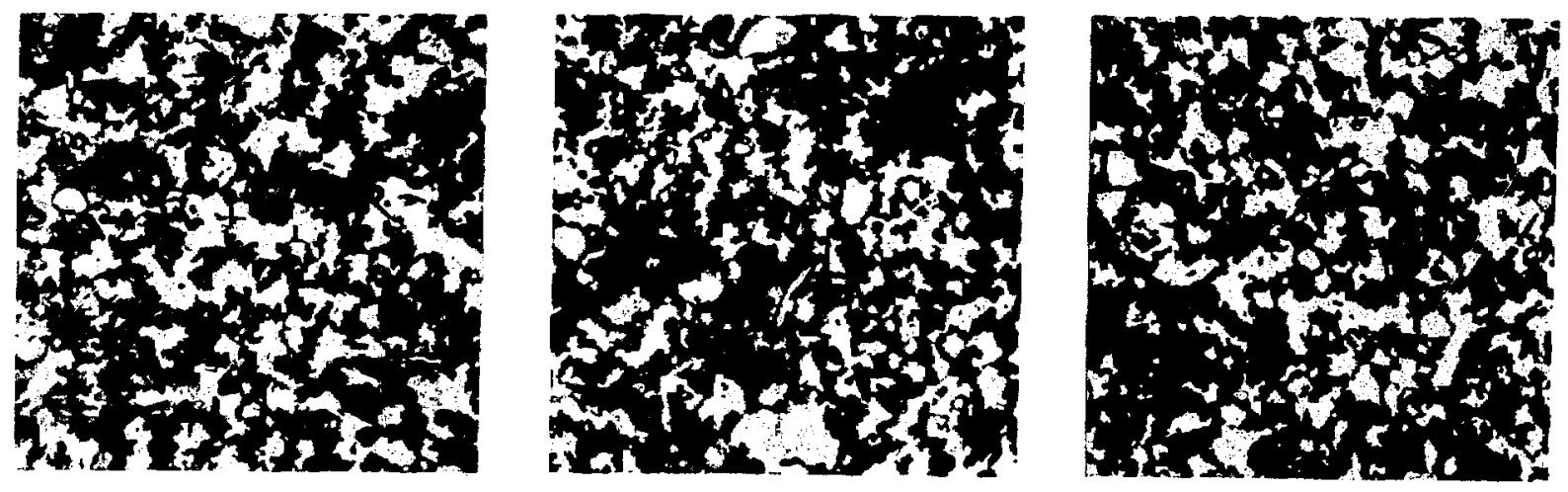

(b)

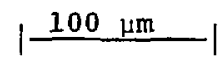

Fig. B8. Photomicrographs of high-fired elements.

(a) Lot 51 (JM-15, 30 volo, $424 \mathrm{~kg} \mathrm{U} / \mathrm{m}^{3}$ )

from High-Fire Run l; (b) Lot 62 ikx-88,

35 vols, $382 \mathrm{~kg} \mathrm{U} / \mathrm{m}^{3}$ ) from High-Fire Run 2.

stations. Variations of the extent of carbide consolidation and the degree of flour reorganization along the length of the element were small, but the MULE data as well as optical and electron microscopy showed that the first several inches of the G-end had been slightly cooler, and electron microscopy showed that the H-end had been the hottest. Lots 50 and 60 from the same high-fire run also had the target structure.

\section{High-Fire Run 4 was conducted conser-} vatively because excessive melting had been found in High-Fire Run 3. Metallography for an element from Lot 62 (Fig. B9) showed that the G-end was hotter than the H-end, but that the target structure was not attained at any station. Lot 63 from the same run, not shown in Fig. B9, did rot attain the target structure at any station either, despite its lower solidus temperature. 
Station 76
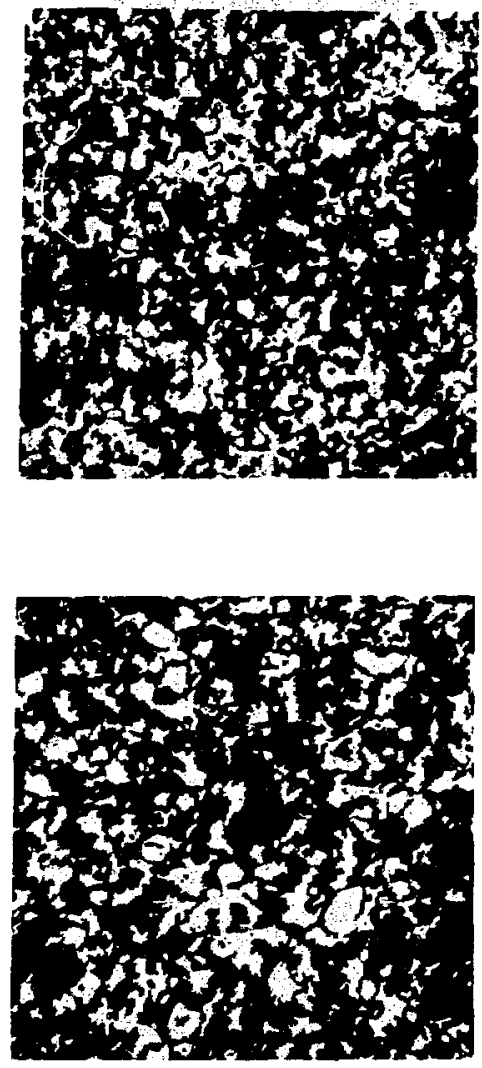

Station 711

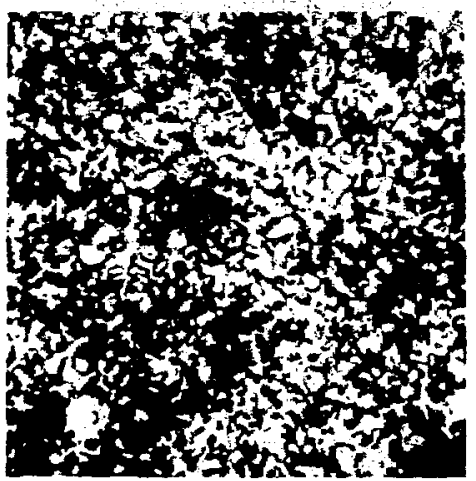

(a)

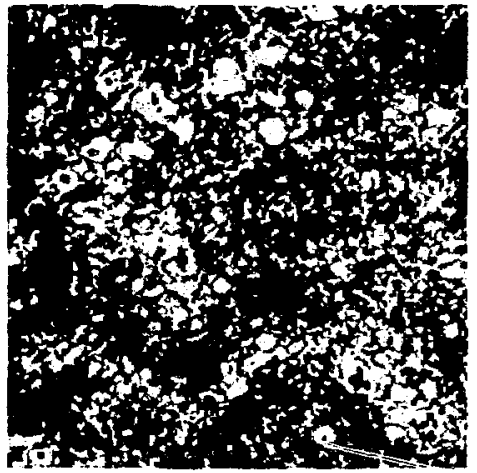

Station 1245
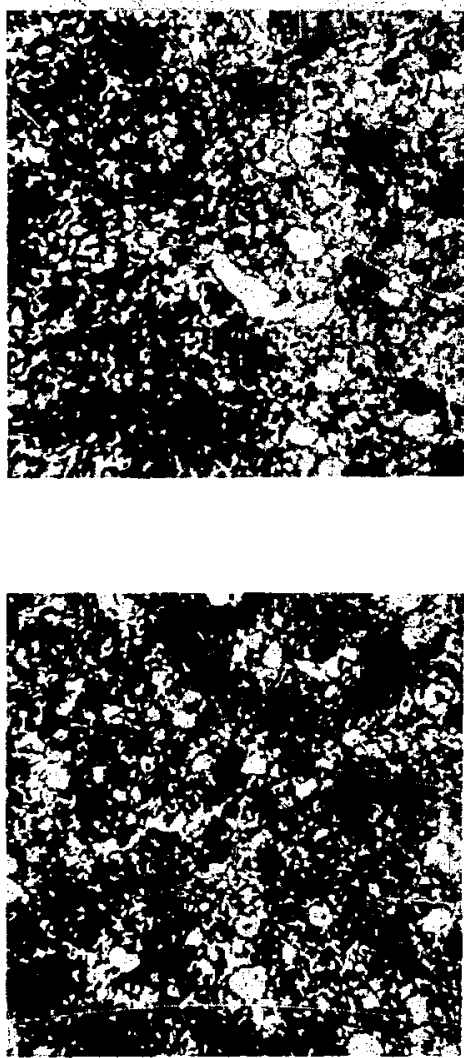

(b)

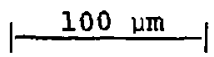

Fig. B9. Photomicrographs of high-fired elements.

(a) Lot 62 (KX-88, 35 vol\%, $382 \mathrm{~kg} \mathrm{U} / \mathrm{m}^{3}$ )

from High-Fire Run 4; (b) Lot 65 ( $\mathrm{KX}-88$,

30 vois, $435 \mathrm{~kg} \mathrm{U} / \mathrm{m}^{3}$ ) from High-Fire Run 6 .

High-Fire Run 6 was also conducted conservatively because excessive melting had been found in High-Fire Run 5. Metallography for an element from Lot 65 (Fig. B9) shows that the G-end was substantially hotter than the $\mathrm{H}$-end. The target structure was attained only in the first few inches at the G-end.
Figures $B 10$ and $B I I$ show photomicrographs of a Lot-52 element that underwent excessive melting in High-Fire Run 5. At Station 76 (Fig.B10) there was evidence of excessive melting at the bore surface that resulted in formation of Type-II graphite (proeutectic graphite, i.e.. graphite precipitated from a melt). The web consistec 


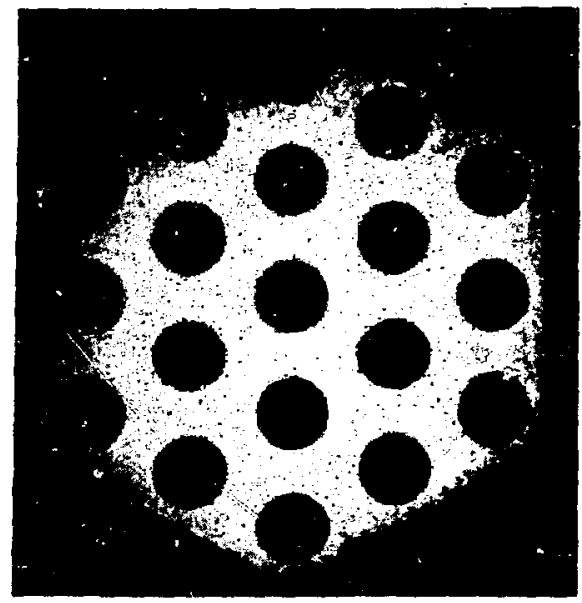

Complete cross section $10 \mathrm{~mm}$

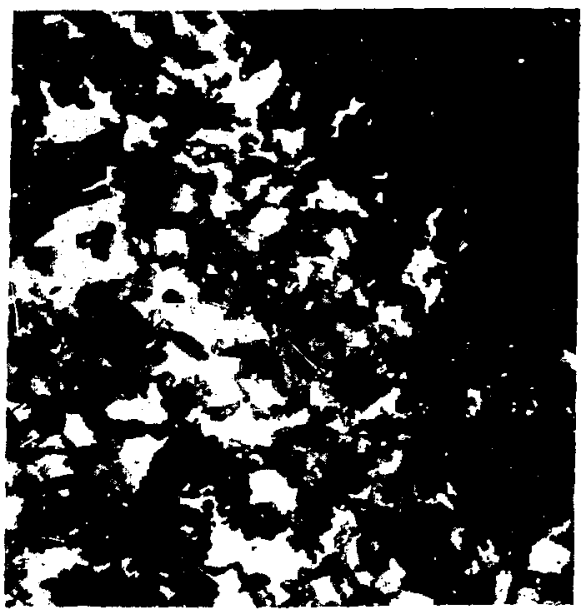

Bore surface arouna center hole

$$
100 \mu \mathrm{m}
$$

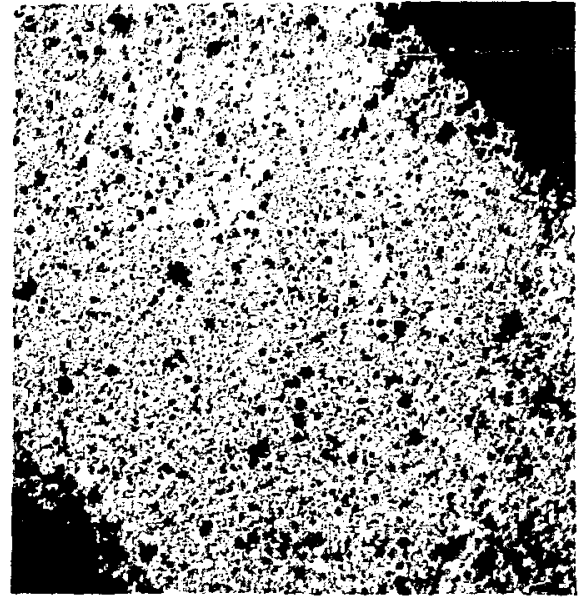

Web around center hole (upper right)

$$
\text { H } 100 \mu \mathrm{m}
$$

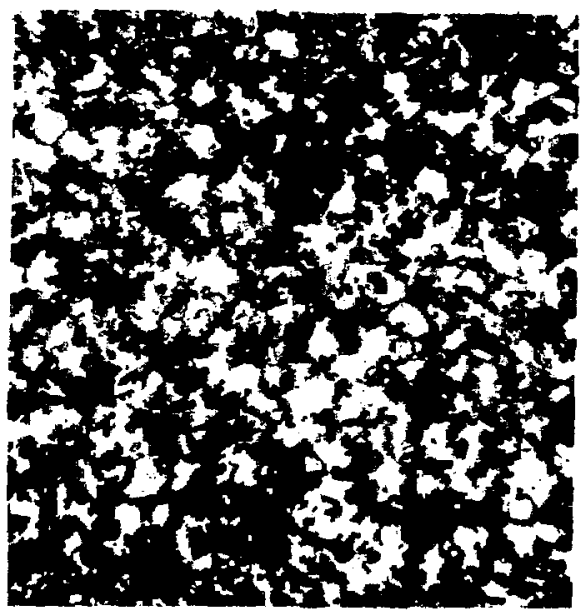

Interior of macrix around center hole

$$
100 \mu \mathrm{m}
$$

Fig. B10. Photomicrographs of Lot 52 element $\left(\mathrm{KX}-88,30 \mathrm{vol} 8,435 \mathrm{~kg} / \mathrm{m}^{3}\right)$ from High-Fire Run 5. Sample was from station 76.

mainly of highly coarsened carbide and extensively reorganized large filler-flour particles. At Station 711 (Fig. Bll) excessive melting extended almost $0.64 \mathrm{~mm}$ into the matrix around each hole, with the results that two-thirds of the $\sim 1.78-\mathrm{mm}$ web between adjacent holes showed excessive melting. The excessively melted region contained large blocks of Type--II graphite and massively coarsened carbide, and was very porous. This region around each hole was highly symmetrical over the entire cross section of the element. The interior of the matrix contained coarsened carbide and high$l_{Y}$ reorganized large filler-flour particles. Metallography of the same element at station 1245 showed microstructures essentially identical to those of Station 76. Chemical analysis of pieces of lot-52 elements from High-Fire Run 3 that showed corresponding microstructures at corresponding axial stations indicated very little residual oxygen and nitrogen as follows: $270-\mathrm{ppm}$ oxygen and 320-ppm nitrogen at Station 1; $140 \mathrm{ppm}$ 


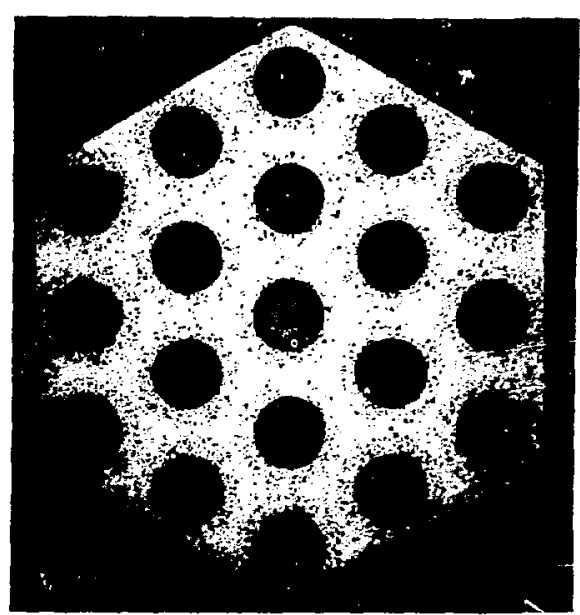

Complete cross section
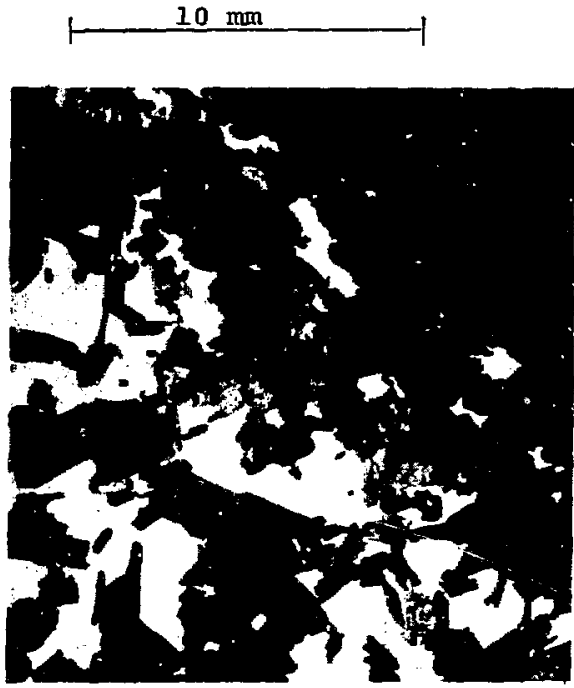

Bore surface around center hole

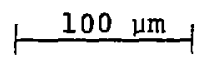

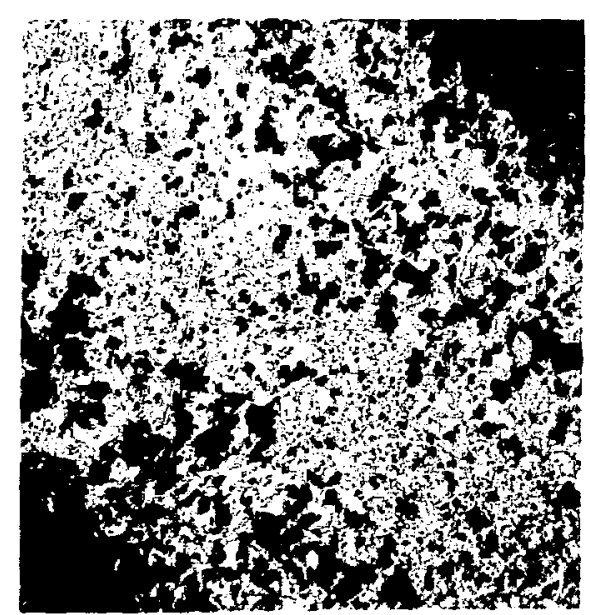

Web around center hole (upper right)

$\longmapsto 100 \mu \mathrm{m}$

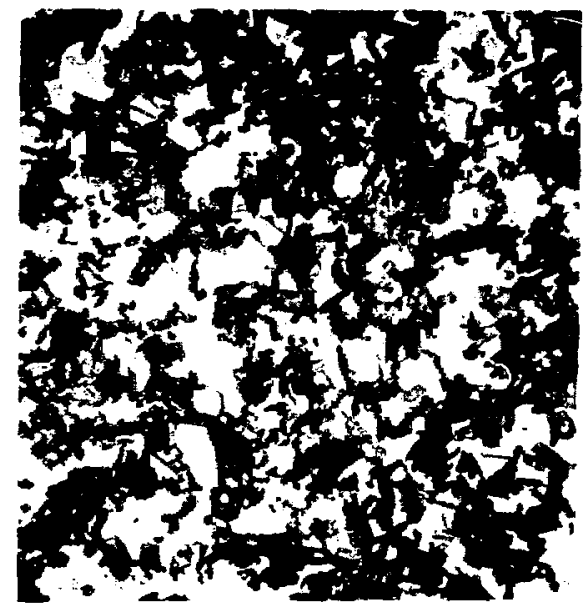

Interior of matrix around center hole

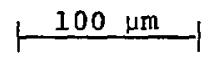

Fig. B1l. Photomicrographs of Lot 52 element (KX-BB, 30 voli, $435 \mathrm{~kg} / \mathrm{m}^{3}$ ) from High-Fire Run 5 . Sample was from station 711 .

oxygen and 280 ppm nitrogen at station 23; and $240 \mathrm{ppm}$ oxygen and $640 \mathrm{ppm}$ nitrogen at Station 51.--A mechanism for the formation of the microstructure shown in Fig. Bll will be suggested after the MuLE data have been presented.

Figure B12 shows photomicrographs for an element from Lot 54 both in the lowfired state, and after High-Fire Run 7. The microstructures of the low-fired pieces appear to be the same for all stations. The microstructures of the pieces from HighFire Run 7 indicate that the G-end of the element was hottest, with coarsening of the carbide and substantial amounts of carbide in the interior of the large filler-flour particles. However, the microstructures of the high-fired pieces from stations 711 and 1245 have essentially the same appearance as low-fired pieces from the same stations, indicating lower temperatures than at the 
Station 76
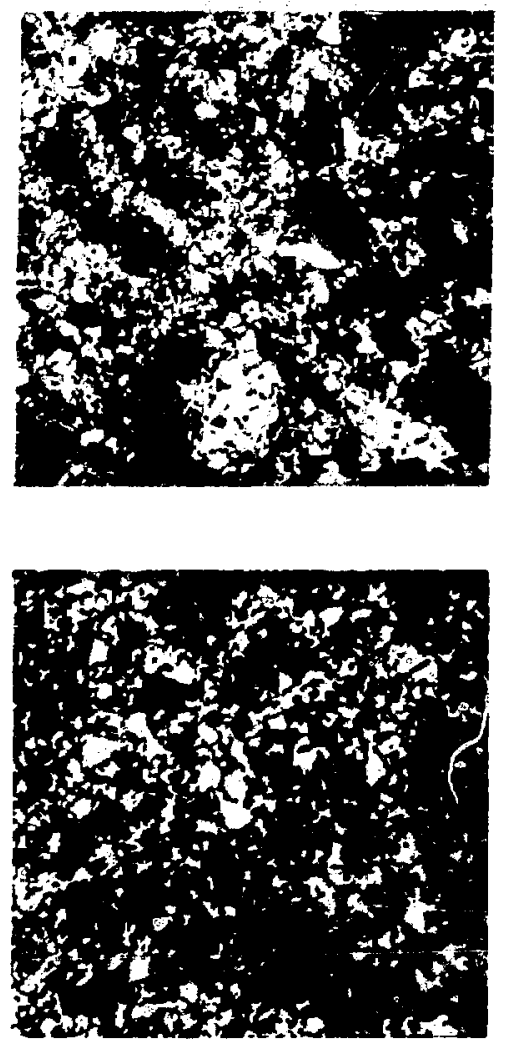

Station 7.11

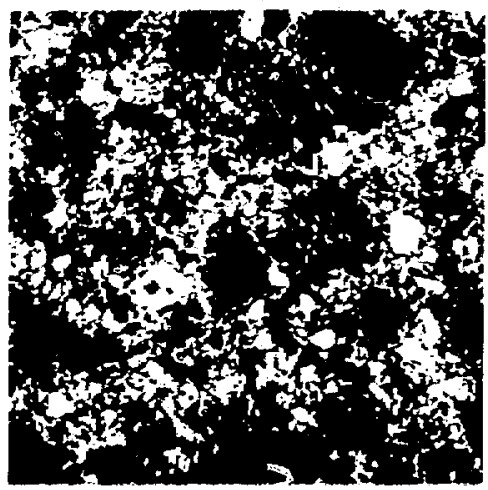

Low-Fire Run 8

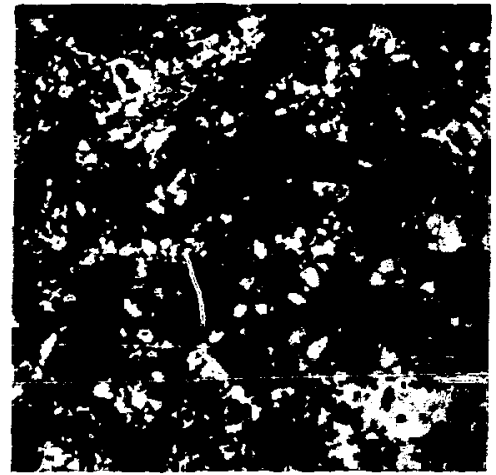

High-Fire Run 7
Station 1245
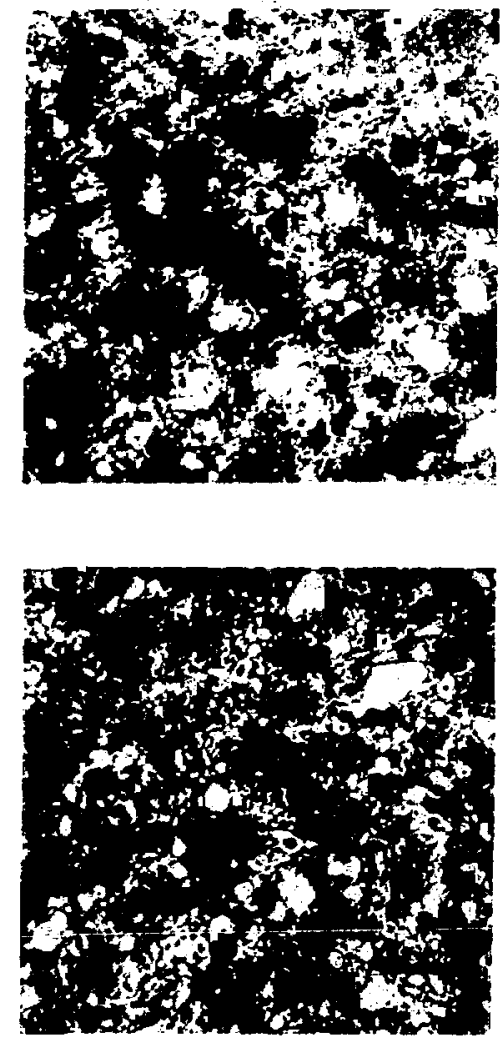

$100 \mu \mathrm{m}$

Fig. B12. Photomicrographs of Lot 54 elenents $\left(\mathrm{Kx}-88,35 \mathrm{vol} 8,725 \mathrm{~kg} / \mathrm{m}^{3}\right.$ )

G-end of the element. The IPDE data indicate the same trend of temperature along the elements from High-Fire Run 7. The resistances were $0.017 \mathrm{\Omega} / \mathrm{m}$ at station 76 and $\vartheta 0.019 \Omega / m$ at stations 711 and 1245 . The characteristics of elements from HighFire Run 7 are important for interpreting the CTE lata for these elements.

\section{IPDE Data}

In general, resistance data for machined, high-fired elements that did not show excessive melting were consistent with metallographic observations. The resistance of the matrix decreased along the length of an element as the extent of coalescence of the carbide in the matrix increased. For these types of elements, the resistance data showed up the cold spots in the fixture adjacent to the line-of-sight ports and gave subtle indications that the elements in the outer ring of the fixture were slightly hotter than the elements in the inner ring. On the other hand, the resistance data for elements that had undergone excessive melting did not vary asj much as the microstructure and the MULE data for such elements.

For elements that did not show excessive melting there appeared to be a sharp drop in resistance as the target structure was approached, i.e., when the solidus temperature was substantially exceeded. Frevious LASL work indicates that the resistance of composite elements decreases linearly with increasing temperature from $\sim 2570 \mathrm{~K}$ to near the solidus temperature. 


\section{MULE Data}

MULE plots have been used for some time as a sensitive indicator of the uniformity of fabrication of fuel elements, not only from element to element, but also along the length of a given element. After final heat-treatment of an element, the elements are machined to uniforn external dimensions. MULE data collected on the machined elements are a measure of the density fluctuations in the elements. Interpretation of the MULE data in conjunction with metallographic and IPDE data has led to a detailed understanding of the fabrication variables that affect the properties of composite matrices. The following generalizations are used in the interpretations: (1) in elements in which no portion of the element has been heated above the solidus, MULE peaks occur in regions of higher temperature because these regions undergo more shrinkage (densification) than those in colder regions; and (2) in elements heated to temperatures considerably above the solidus the liquid carbide present moves to regions of lower temperature, resulting in MULE peaks in the colder regions and MULE valleys in the hotter regions.

\section{5. $\mathrm{x}$-ray Diffraction}

\section{x-ray diffraction investigations}

of the $(U, \mathrm{Zr}) \mathrm{C}$ carbide in composite elements was of some help in interpreting the final heat-treatment temperatures and cooldown rates. In general, phases present in less than 258 quantities were not detected. Composite marerial heated above the solidus temperature will show $(U, 2 r) C$ solid solution of uniforn composition if cooled slowly enough to reach equilibrium or may show solid solution of variable composition if cooled too rapidly to reach equilibriun. In the latter case, a solid-solution composition lower and higher than the nominal composition would be expected. (See Fig. 3, the pseudobinary phase diagram, in the main body of the report.) Some $x$-ray diffraction results were anomalous relative to the above discussion.
The x-ray diffraction data, Table BV, for the four elements in High-Fire Run 1 showed that the elements with the lower uranium atom ratios (solidus temperature, ح $3030 \mathrm{k}$ ) were single-phase while the two with higher uranium atom ratios (solidus temperature, $2970 \mathrm{~K}$ ) had soiid solutions of two different chemical compositions. The reported heat-treatinent temperature was $3020 \mathrm{~K}$. The elements with the lower uranium atom ratio had $(U, \mathrm{zr}) \mathrm{C}$ of only one chemical composition. The elements probably did not contain liquid carbide during heat-treatment and the cooling rate did not affect the solid-solution composition. However, the two elements with the higher uranium atom ratios probably contained liquid carbide during heat-treatment. On cooldown, equilibrium was not reached, and solid solutions of two differen: compositions were found by $x$-ray diffracticn to be present at room temperature.

This type of explanation does not readily account for the presence of solid solutions of two different compositions in the elements from High-Fire Runs 4 and 5. All elements in High-Fire Run 2 were heattreated at temperatures above the solidus and, on cooling, formed a solid solution essentially of one composition. The elements in High-Fire Run 7 were heated to a temperature below the solidus and they, too, contained solid solution of only one composition. Attempts to explain oome of these results on the basis of different cooling rates that might be dependent upon location of the elements in the heat-treating fixture have not cleared up these apparent anomalies in the x-ray diffraction data.

\section{Permeability}

Table BVI presents the permeability data for machined, high-fired composite elements. GL-1076 filler flour gave a substantially less permeable matrix than aid either $\mathrm{kX}-88$ or $\mathrm{JM}-15$, for all loadings. In High-Fire Run 7, GL-1076 gave the least permeable elements, JM-15 gave the most 


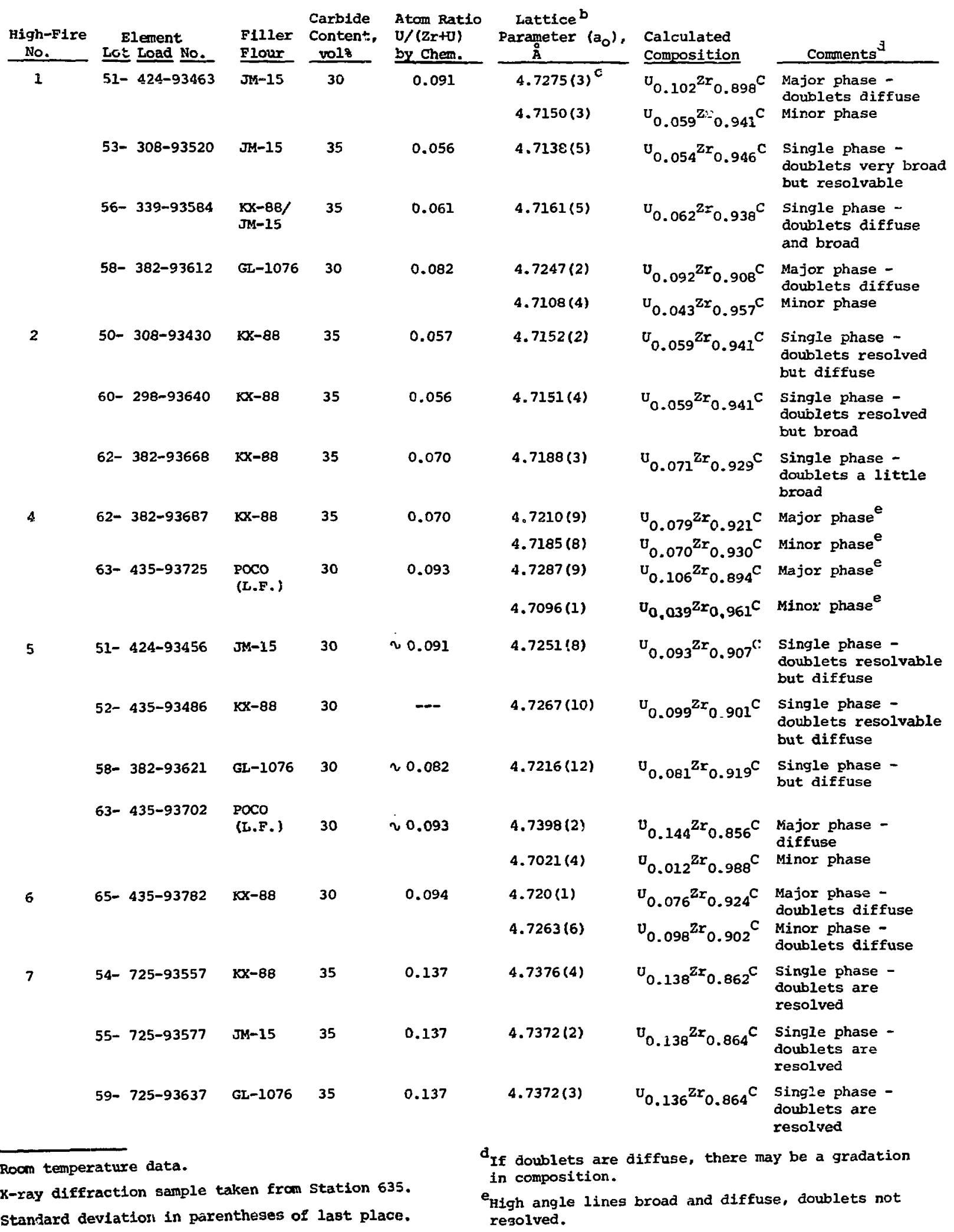




\begin{tabular}{|c|c|c|c|c|c|c|c|}
\hline $\begin{array}{c}\text { High-Fire } \\
\text { No. }\end{array}$ & $\begin{array}{l}\text { Lot } \\
\text { No. }\end{array}$ & $\begin{array}{l}\text { Filler } \\
\text { Flour }\end{array}$ & $\begin{array}{l}\text { Carbide } \\
\text { Content, } \\
\text { voli } \\
\end{array}$ & $\begin{array}{l}\text { U, Loading, } \\
\mathrm{kg} / \mathrm{m}^{3}\end{array}$ & $\begin{array}{l}\text { Elements } \\
\text { Measured } \\
\end{array}$ & $\frac{\text { Permeability, m }}{\text { Range }}$ & $\frac{\mathrm{a}^{3} / \mathrm{s} \text { of air }}{\text { Average }}$ \\
\hline \multirow[t]{4}{*}{1} & 51 & $J M-15$ & 30 & 424 & 9 & $200-530 \times 10^{-8}$ & $300 \times 10^{-8}$ \\
\hline & 53 & $\mathrm{JM}-15$ & 35 & 308 & 10 & $53-200$ & 123 \\
\hline & $56^{d}$ & $\mathrm{KXX}-88 / \mathrm{JM}-15$ & 35 & 339 & 8 & $183-432$ & 274 \\
\hline & 58 & GL-1076 & 30 & 382 & 8 & $36-50$ & 42 \\
\hline \multirow[t]{3}{*}{2} & $50^{d}$ & $\mathrm{KX}-88$ & 35 & 308 & 17 & $10-70$ & 33 \\
\hline & 60 & $\mathrm{KX}-88$ & 35 & 298 & 7 & $42-96$ & 65 \\
\hline & $62^{\mathrm{d}}$ & $\mathrm{KX}-88$ & 35 & 382 & 12 & $10-46$ & 28 \\
\hline \multirow[t]{2}{*}{3} & 52 & $\mathrm{KX}-88$ & 30 & 435 & 17 & $10-7600$ & $\mathrm{NA}^{\mathrm{b}}$ \\
\hline & 61 & $k x-88$ & 30 & 343 & 14 & $8-40$ & 20 \\
\hline \multirow[t]{2}{*}{4} & $62^{\mathrm{d}}$ & $\mathrm{KX}-88$ & 35 & 382 & 7 & $216-365$ & 304 \\
\hline & 63 & POCO (L.F.) & 30. & 435 & 10 & $730-1230^{c}$ & 1020 \\
\hline \multirow[t]{4}{*}{5} & 51 & $\mathrm{JM}-15$ & 30 & 424 & 3 & $12000-16000$ & NA \\
\hline & 52 & $k x-88$ & 30 & 435 & 7 & $1600-12000$ & MA \\
\hline & 58 & GL- 1076 & 30 & 382 & 5 & $365-1600$ & NA \\
\hline & 63 & POCO (L.F.) & 30 & 435 & 7 & $500-8300$ & NA \\
\hline \multirow[t]{2}{*}{6} & 65 & $\mathrm{KXX}-88$ & 30 & 435 & 17 & $330-813$ & 455 \\
\hline & 66 & $\mathrm{rx}-88$ & 30 & 343 & 14 & $450-580$ & 495 \\
\hline \multirow[t]{3}{*}{7} & $54^{\mathrm{e}}$ & $\mathrm{kX}-88$ & 35 & 725 & 18 & $2300-3100$ & 2600 \\
\hline & $55^{e}$ & $J M-15$ & 35 & 725 & 6 & $3100-3800$ & 3400 \\
\hline & $59^{e}$ & GL-1076 & 35 & 725 & 7 & $960-1400$ & 1200 \\
\hline
\end{tabular}

\footnotetext{
Whole element permeability using 0.07 -MPa differential air pressure.

$b_{\mathrm{NA}}=$ not applicable bevause of excessive melting of portions of the matrix.

$\mathrm{C}_{\text {The Lot }} 63$ elements had fine matrix cracks.

done element from each of Lots 50,56 , and 62 had permeability measured is the machined, low-fired condition. Permeability data were:
}

$\begin{array}{ccc}\text { Lot No. } & \text { Low-Fire No. } & \text { Permeability, } \mathrm{m}^{3} / \mathrm{s} \text { of aix } \\ 50 & 7 & 580 \\ 56 & 7 & 730 \\ 62 & 4 & 330\end{array}$

Five elements from each of Lots 54, 55, and 59 were machined in the low-fired condition for coating. There were no abnormal permeability values. Permeability data were:

$\begin{array}{ccc}\text { Lot No. } & \text { Iow-Fire No. Average Pexmeability, } \mathrm{m}^{3} / \mathrm{s} \text { of air } \\ 54 & 8 & 2100 \\ 55 & 9 & 2100 \\ 59 & 8 & 870\end{array}$




\begin{tabular}{|c|c|c|c|c|c|c|c|c|c|c|c|c|}
\hline \multirow{2}{*}{$\begin{array}{l}\text { Lot } \\
\text { No. }\end{array}$} & \multirow{2}{*}{$\begin{array}{l}\text { Serial } \\
\text { Number } \\
\end{array}$} & \multicolumn{2}{|c|}{$\begin{array}{c}\text { Carbide Content, } \\
\text { voli }\end{array}$} & \multirow{2}{*}{$\begin{array}{c}\text { Nominal } \\
\text { U Loading, } \\
\mathrm{kg} / \mathrm{m}^{3} \\
\end{array}$} & \multirow{2}{*}{$\begin{array}{c}\text { Grogs } \\
\text { Densitty, } \\
\text { Mg/m }{ }^{3}\end{array}$} & \multicolumn{2}{|c|}{$\mathbf{z r}$} & \multicolumn{2}{|c|}{$\mathbf{u}$} & \multicolumn{2}{|c|}{ C } & \multirow{2}{*}{$\begin{array}{l}\text { Ta } \\
\text { ppm }\end{array}$} \\
\hline & & Nominal & Actual & & & $\underline{\text { Gto }}$ & $\mathrm{mg} / \mathrm{m}^{3}$ & Wto & $\mathrm{kg} / \mathrm{m}^{3}$ & WE8 & $\mathrm{Mg} / \mathrm{m}^{3}$ & \\
\hline 50 & 93430 & 35 & 35.2 & 308 & 3.561 & 53.9 & 1.92 & 8.43 & 300.2 & 37.5 & 1.34 & 130 \\
\hline 51 & 93403 & 30 & 30.2 & 424 & 3.360 & 47.0 & 1.58 & 12.11 & 406.9 & 40.8 & 1.37 & 90 \\
\hline 53 & 93520 & 35 & 35.2 & 308 & 3.564 & 54.0 & 1.92 & 8.21 & 292.6 & 37.6 & 1.34 & 150 \\
\hline 54 & 93557 & 35 & 36.2 & 725 & 3.723 & 47.9 & 1.78 & 19.64 & 731.0 & 32.1 & 1.195 & 70 \\
\hline 55 & 93577 & 35 & 36.3 & 725 & 3.754 & 47.7 & 1.79 & 19.48 & 731.0 & 32.6 & 1.224 & 60 \\
\hline 56 & 93584 & 35 & 35.1 & 339 & 3.568 & 53.4 & 1.91 & 8.96 & 319.7 & 37.4 & 1.33 & 170 \\
\hline 58 & 93612 & 30 & 30.1 & 382 & 3.351 & 47.5 & 1.59 & 10.90 & 365.3 & 41.5 & 1.39 & 130 \\
\hline 59 & 93637 & 35 & 36.7 & 725 & 3.768 & 48.0 & 1.81 & 19.61 & 739.0 & 32.3 & 1.217 & 35 \\
\hline 60 & 93640 & 35 & 34.6 & 298 & 3.518 & 53.8 & 1.89 & 8.22 & 289.2 & 37.5 & 1.32 & 100 \\
\hline 62 & $93668^{b}$ & 35 & 35.1 & 382 & 3.561 & 52.9 & 1.88 & 10.20 & 363.2 & 36.7 & 1.31 & 100 \\
\hline 62 & $93687^{b}$ & 35 & 35.0 & 382 & 3.557 & 52.8 & 1.88 & 10.31 & 366.7 & 36.9 & 1.31 & 90 \\
\hline 63 & 93725 & 30 & 30.3 & 435 & 3.342 & 47.3 & 2.58 & 12.43 & 415.4 & 40.3 & 1.35 & 50 \\
\hline 65 & 93762 & 30 & 30.1 & 435 & 3.362 & 46.6 & 1.56 & 12.50 & 420.0 & 40.5 & 1.362 & 55 \\
\hline
\end{tabular}

all samples taken from station 1245.

blement 93668 from High-Fire Run 2, maximm temp. $3075 \mathrm{~K}$. Element 93687 from High-Fire Run 4, maximum temp. $3025 \mathrm{k}$.

permeable elements, and $\mathrm{KX}-88$ was in between. Note (see Footnote $e$ of Table BVI) that machined elements of all lots were more permeable after High-Fire Run 7 than arter the preceding low firing. Consolidation of the matrix of Lot 62 in High-Fire Run 2 led to much lower permeability values than were obtained in High-Fire Run 4 or in low firing (see Footnote d for the latter). The same was true for Lot 50 after High-Fire Run 2 relative to the low-fired condition (see Footnote d). The elenents that showed excessive melting in High-Fire Runs 3 and 5 had either highly variable or consistently high permeability, depending on the lot.

\section{Chemistry}

The results of chemical analyses are given in Table BVII. In general, the intended carbide content was attained rairly closely. The actual uraniurn loadings were somewhat lower than the nominal (intended) loadings for all lots with mediun loadings, whereas they were slightly higher for all lots with high loadings. Such variations are to be expected in initial work with new flours. The loading deviations did not change the expected solidus temperatures by more than $\sim 10 \mathrm{~K}$, and the preceding discussions involving solidus temperatures based on nominal loadings are therefore still valid.

\section{MATRIX PROPERTIES}

\section{A. Microstructure}

The matrix target structure is compared in Fig. B2 with that of Lot-62 elements that had been heated at various temperatures. The elements heated at $\sim 3070 \mathrm{~K}$ in High-Fire Run 2 attained the target structure, whereas the elements heated at ح $3020 \mathrm{~K}$ in High-Fire Run 4 did not. Metallographic examination of polished sections and electron microscopic examination of two-stage replicas of these sections revealed striking differences in the matrices resulting from these two high-fire runs. A Lot-62 element heated at $\sim 3020 \mathrm{~K}$ in 
High-Fire Run 4 showed the following features at station 25, 355, 735, and 1170:

(a) no carbon-black particles or traces of binder residue were found; (b) Type-I reorganized graphite surrounded much of the carbide; (c) the carbide was coalesced but some small carbide particles were present; (d) original $\mathrm{kX}-88$ filler was present, and small carbide particles that aid not appear to be connected to the main body of coalesced carbide were found within the filler particles; and (e) voids generally had TypeI reorganized graphite at their peripheries. A Lot-62 element heated at $3070 \mathrm{~K}$ in HighFire Run 2 showed the following features at Stations 25, 355, 735, and 1170: (a) no carbon-black particles or traces of binder residue were found; (b) Type-I reorganized graphite was present adjacent to some carbides at all stations, whereas some blocky Type-II reorganized graphite may have been present at Station 1170; (c) the carbide was well coalesced, to the greatest extent at station 1170: (d) none of the structure of the small random jomains of $\mathrm{KX}-88$ filler was found, the reorganized filler became more blocky is the station increased, small carbide particles that did not appear to be connected to the main body of coalesced carbide were within the reorganized filler, and blocky reorganized filler contained angular voids; and (e) voids, excluding the abovementioned angular ones, had scalloped edges and were generally bounded by Type-I graphite for specimens up to station 735, but many of the voids at station 1170 were very angular and had straighter edges than the voids at lower stations. Microscopy of the latter element illustrates the variations in the microstructure that can be seen in an element having the target structure.

\section{B. Carbide Network Structure}

A piece of a Lot- 62 element heated at $\sim 3020 \mathrm{~K}$ in High-Fire Run 4 and a piece of another Lot-62 element heated at $\sim 3070 \mathrm{~K}$ in High-Fire Run 2 lelements from the lot for which metallography is shown in Fig. B2) were leached in 1 -atm $\mathrm{H}_{2}$ for $240 \mathrm{~h}$ at $~$ $1800 \mathrm{~K}$. Comparison of mass losses with chemistry data for the starting material showed that 998 of the free carbon was leached from both pieces. The leached pieces did not change their shape or dimensions as a result of the leaching. Figure B2 shows scanning-electron-microscope (SEM) pictures of the residual interconnected network of carbide (carbide cage structure). Heating the matrix to a nominally 50-K higher temperature drastically increased the coarseness of the carbide particles in the network and doubled the room-temperature axial crushing strength of the carbide cage structure, from 5.5 to $11.7 \mathrm{MPa}$.

\section{c. Coefficient of Thermal Expansion}

Table BVIII lists CTE data for composite elements with medium loadings and, below the broken line, with high loadings.

For medium loadings the following conclusions can be drawn from the CTE data:

- The coefficients of thermal expansion of matrices from the NF-1 experiment were substantially higher than those of matrices containing s-97 filler flour.

- The CTE increased with carbide content for comparable heat-treatment.

- The CTE of a matrix containing $\mathrm{kX}-88$ filler flour appears to be insensitive to heat-treatment temperature (see Lots 50 and 62).

- The CTE of a matrix containing JM-15 filler flour, and parhaps POCO (L.F.) filler flour, was sensitive to heat-treatment temperature.

- The CTE of matrices from the NF-1 experiment were more isotropic than the CTE of matrices containing s-97 filler flour, with the matrix containing poco (L.F.) filler flour befing virtually isotropic.

- Most important, coefficients in the longitudinal orientation above $6.8 \mu \mathrm{m} / \mathrm{m} \cdot \mathrm{K}$ 
COEFFICIENT OF THERMAL EXPANSION OF UNCOATED COMPOSITE ELEMENTS FROM THE NF- I EXPERIMENT

\begin{tabular}{|c|c|c|c|c|c|c|}
\hline \multirow{2}{*}{$\begin{array}{l}\text { Filler } \\
\text { Flour } \\
\end{array}$} & \multirow{2}{*}{$\begin{array}{l}\text { Carbide } \\
\text { Content, } \\
\text { vols }\end{array}$} & \multirow{2}{*}{$\frac{\text { Element }}{\text { Lot Load No. }}$} & \multirow{2}{*}{$\begin{array}{l}\text { Heat- } \\
\text { Treatment } \\
\text { Temp. K }\end{array}$} & \multicolumn{2}{|c|}{$\begin{array}{c}\operatorname{CTE}(293-2300 \mathrm{~K}) \\
\mu \mathrm{m} / \mathrm{m} \cdot \mathrm{K}\end{array}$} & \multirow{2}{*}{$\begin{array}{c}\text { CTE } \\
\text { Ratio } \\
\text { Trans./Long. }\end{array}$} \\
\hline & & & & Long. & Trans. & \\
\hline $5-97$ & 30 & $100-500$ load & 2970 & 6.1 & 6.8 & 1.10 \\
\hline \multirow[t]{4}{*}{$k X-88$} & 30 & $65-435-93782$ & 2945 & 6.5 & 6.8 & 1.04 \\
\hline & 35 & $60-298-93640$ & 3050 & 6.6 & 6.9 & 1.03 \\
\hline & & $\begin{array}{l}50-308-93452 \\
50-308-93430\end{array}$ & $\begin{array}{l}2635 \\
3050\end{array}$ & $\begin{array}{l}6.7 \\
6.7\end{array}$ & $\begin{array}{l}6.9 \\
6.9\end{array}$ & $\begin{array}{l}1.03 \\
1.03\end{array}$ \\
\hline & & $\begin{array}{l}62 \quad 382-93701 \\
62-382-93687 \\
62-382-93668\end{array}$ & $\begin{array}{l}2635 \\
3025 \\
3050\end{array}$ & $\begin{array}{l}6.8 \\
6.6 \\
6.8\end{array}$ & $\begin{array}{l}7.2 \\
6.9 \\
7.0\end{array}$ & $\begin{array}{l}1.05 \\
1.05 \\
1.03\end{array}$ \\
\hline \multirow[t]{2}{*}{$J M-15$} & 30 & $51-424-93463$ & 3010 & 6.5 & 6.6 & 1.03 \\
\hline & 35 & $\begin{array}{l}53-308-93514 \\
53-308-93520\end{array}$ & $\begin{array}{l}2570 \\
3010\end{array}$ & $\begin{array}{l}7.1 \\
6.7\end{array}$ & $\begin{array}{l}7.2 \\
6.8\end{array}$ & $\begin{array}{l}1.01 \\
1.02\end{array}$ \\
\hline $\mathrm{KX}-88 / \mathrm{JM}-15$ & 535 & $56-339-93584$ & 3010 & 6.7 & 7.0 & 2.05 \\
\hline GL-1076 & 30 & $58-382-93612$ & 3010 & 6.5 & 6.8 & 1.05 \\
\hline POCO (I.F.) & 30 & $\begin{array}{r}63-435-93728 \\
63-435-93725\end{array}$ & $\begin{array}{l}2635 \\
3025\end{array}$ & $\begin{array}{l}7.0 \\
6.7\end{array}$ & $\begin{array}{l}7.0 \\
6.7\end{array}$ & $\begin{array}{l}1.00 \\
1.00\end{array}$ \\
\hline$K x-88$ & 35 & $\begin{array}{l}54-725-93529 \\
54-725-93557\end{array}$ & $\begin{array}{l}2610 \\
2785\end{array}$ & $\begin{array}{l}7.0 \\
7.0\end{array}$ & 7.0 & $\underline{1.00}$ \\
\hline$J M-15$ & 35 & $\begin{array}{l}55-725-93572 \\
55-725-93577\end{array}$ & $\begin{array}{l}2610 \\
2785\end{array}$ & $\begin{array}{l}7.1 \\
7.1\end{array}$ & $\begin{array}{l}7.3 \\
-.2\end{array}$ & 1.02 \\
\hline GL-1076 & 35 & $\begin{array}{l}59-725-93631 \\
59-725-93637\end{array}$ & $\begin{array}{l}2610 \\
2785\end{array}$ & $\begin{array}{l}7.1 \\
7.2\end{array}$ & $\begin{array}{l}7.1 \\
---\end{array}$ & 1.00 \\
\hline
\end{tabular}

were not obtained for medium loadings with any flour used in the $N F-1$ experiment for heat-treatment temperatures above $2970 \mathrm{k}$.

The coefficients in the longitudinal direction for all low-fired elements with uranium loadings of $725 \mathrm{~kg} / \mathrm{m}^{3}$ were 7.0 to $7.1 \mu \mathrm{m} / \mathrm{m} \cdot \mathrm{k}$. The same elements heated to $\sim 2790 \mathrm{~K}$ had coefficients of 7.0 to 7.2 $\mu \mathrm{m} / \mathrm{m} \cdot \mathrm{K}$. This heat-treatment temperature over most of the length of the elements was too low to substantially alter the low-fired structure and the expansion properties. It is not known whether the CTE would remain at these high values if the entire element had been heated high enough to produce the target structure.

CTE measurements were made of three samples from an excessively melted element from High-Fire Run 3 . The longitudinal expansion values were $6.6,6.6$, and $6.3 \mu \mathrm{m} / \mathrm{m} \cdot \mathrm{K}$ for samples from stations 380,810 , and 1170, respectively (the amount of melting decreased with increasing station). The CTE for elements of this type heated close to the solidus temperature is $\sim 6.5 \mu \mathrm{m} / \mathrm{m} \cdot \mathrm{K}$. Thus, no large differences in expansion were encountered in the excessively heated material.

\section{Thermal Conductivity}

Table BIX shows room-temperature thermal conductivity data, derived from thermal diffusivity, for elements from High-Fire Runs 1, 2, 4, 6, and 7. The measurements were made by the flash-diffusivity technique; a helical xenon flash lamp surrounding the nominal 6.1-mm-o.d. by $2.6-m m-i . d$. by 100-mm-long specimen was used with a detector thermocouple probing the interior of the specimen. The specimens had been 
TABIE BIX

ROOM-TEMPERATURE THERMAI CONDUCTIVITY FOR NF-1 EXPERIMENT AND COMPARISON ELEMENTS

\begin{tabular}{|c|c|c|c|c|c|c|}
\hline $\begin{array}{l}\text { High-Fire } \\
\text { - o. }\end{array}$ & $\begin{array}{c}\text { Elemerst } \\
\text { Lot Load No. }\end{array}$ & $\begin{array}{l}\text { Filler } \\
\text { Flour } \\
\end{array}$ & $\begin{array}{l}\text { Carbide } \\
\text { Content, } \\
\text { voli } \\
\end{array}$ & $\begin{array}{c}\text { Sample } \\
\text { Location }\end{array}$ & $\begin{array}{l}\text { Heat-Treatment } \\
\text { Temp., K }\end{array}$ & $\begin{array}{l}\text { Thermal } \\
\text { Conductivity, } \\
\mathrm{W} / \mathrm{m} \cdot \mathrm{K}\end{array}$ \\
\hline \multirow[t]{4}{*}{$\perp$} & 51-424-93466 & $\mathrm{JM}-15$ & 30 & $M \in H$ & 3030 & 87 \\
\hline & $53-308-93528$ & $J M-15$ & 35 & $M \& \mathbf{H}$ & 3030 & 75 \\
\hline & $56-339-93591$ & $K X-88 / J M-15$ & 35 & $\mathbf{M} \& \mathbf{H}$ & 3030 & 76 \\
\hline & $58-382-93618$ & GL-1076 & 30 & $M \&$ B & 3030 & 78 \\
\hline \multirow[t]{3}{*}{2} & $50-308-93436$ & $\mathrm{KX}-88$ & 35 & $M \& \mathrm{~B}$ & 3060 & 81 \\
\hline & $60-298-93645$ & $k x-88$ & 35 & $M \& \mathrm{E}$ & 3060 & 85 \\
\hline & $62-382-93674$ & $k x-88$ & 35 & $M \propto \mathbf{H}$ & 3060 & 87 \\
\hline \multirow[t]{2}{*}{4} & $62-382-93683$ & $k x-88$ & 35 & $M \& H$ & 3020 & 71 \\
\hline & $63-435-93718$ & $\operatorname{POCO}\left(L_{.} F_{.}\right)$ & 30 & $M \& H$ & 3020 & 69 \\
\hline 6 & $\begin{array}{r}65-435-93781 \\
-93790\end{array}$ & $\begin{array}{l}\mathrm{KX}-88 \\
\mathrm{KX}-88\end{array}$ & $\begin{array}{l}30 \\
30\end{array}$ & $\begin{array}{l}M \mathbf{E}^{\mathbf{B}} \\
\mathbf{G} \\
\mathbf{H}\end{array}$ & $\begin{array}{r}2955 \\
2945 \\
2945\end{array}$ & $\begin{array}{l}62 \\
93 \\
68\end{array}$ \\
\hline 7 & $54-725-93558$ & $x x-88$ & 35 & $M \& \mathrm{H}$ & 2780 & 49 \\
\hline \multirow[t]{2}{*}{9} & $69-424-93903$ & $k X-88$ & 30 & $\begin{array}{l}\text { G } \\
\text { H }\end{array}$ & $\begin{array}{r}2890 \\
2940\end{array}$ & $\begin{array}{l}80 \\
72\end{array}$ \\
\hline & -93904 & $k x-88$ & 30 & $\begin{array}{l}\mathbf{G} \\
\mathbf{H}\end{array}$ & $\begin{array}{r}2890 \\
2940\end{array}$ & $\begin{array}{l}81 \\
69\end{array}$ \\
\hline WANL & $8-413-203205$ & GL-1074 & 30 & $\begin{array}{l}\text { M } \\
\mathbf{H}\end{array}$ & $\begin{array}{l}3020 \\
3020\end{array}$ & $\begin{array}{l}\sim 80 \\
\sim 80\end{array}$ \\
\hline - & $68-500-92025$ & s-97 & 30 & H & $<2970$ & 61 \\
\hline - & $68-500-92011$ & $s-97$ & 30 & $\begin{array}{l}\mathbf{G} \\
\mathbf{M} \\
\mathbf{H}\end{array}$ & $\begin{array}{l}<2970 \\
\sim 2970 \\
<2970\end{array}$ & $\begin{array}{l}54 \\
76 \\
59\end{array}$ \\
\hline- & $713-339-62155$ & $s-97$ & 30 & $\begin{array}{ll}\text { Sta. } 50 \\
\text { Sta. } 330 \\
\text { Sta. } 500 \\
\text { Sta. } 790 \\
\text { Sta. } 965 \\
\text { Sta. } 1270\end{array}$ & $\begin{array}{l}<2970 \\
<2970 \\
\sim 2970 \\
\sim 2970 \\
<2970 \\
<2970\end{array}$ & $\begin{array}{l}47 \\
51 \\
54 \\
53 \\
49 \\
41\end{array}$ \\
\hline
\end{tabular}

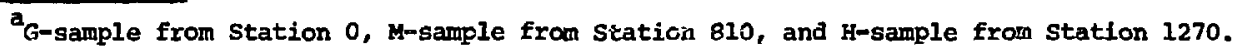

trepanned from around the central hole (Hole 10) of the fuel elements. In all elements except one, the samples were from stations 760 to 860 and 1220 to 1320 . The diffusivity data for each element were the average Cf at least two determinations at points $180 \mathrm{deg}$ apart, $38 \mathrm{~mm}$ from the end of the tube. The data agreed within experimental preciston and were averaged for calculating thermal conductivity. Also included in Table BIX are data for several materials for comparison (below broken line). For those elements, which were not uniform along their lengths, values for individual samples are 1 isted.

Figure B13 depicts the extraordinarily high thermal conductivities of a Lot-52 element that showed excessive melting in HighFire Run 5 (see Figs. BlO and B11). Several values are higher than the room-temperature thermal conductivity of ATJ-S graphite and must be attributed to the crystalline character of the graphite in the composite matrix.

The thermal conductivity of a composite matrix clearly is determined primarily by the thermal conductivity of the carbon phase. 


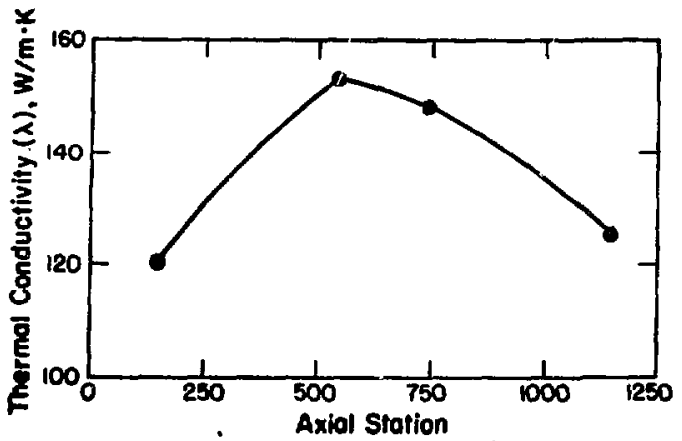

Fig. B13. Room-temperature thermal conductivity of Element 52-43593486 that showed excessive melting in High-Fire Run 5.

The contribution of the carbide cage structure would be expected to be substantially less than the $i 25 \mathrm{~W} / \mathrm{m} \cdot \mathrm{K}$ for dense $\mathrm{zrc}$. The degree of reorganization of polygonization of the filler flour that occurs at temperatures near and above the solidus temperature of the composite matrix clearly is the important factor because the carbon blacks and binder residues have earlier been converted to Type-I graphite.

\section{E. Thermal-Shock Resistance (ZAP Test)}

Thermal-shock data for 13 lots of uncoated, machined composite elements were obtained by using the thermal-shock apparatus previously developed for circular disk specimens. The measurements were made on 1.6mm-thick cross-sectional wafers cut from the G-end, middle, and H-end of the elements.

The results of these measurements, summarized in Table $B X$, were very reproducible for most materials; however, in some sections of a few elements the data were widely scatterta. These anomalous results were traced to the presence of extrusion flaws.

Some specimens from elements heated in High-Fire Run 5, for which MuLE data indicated excessive melting in portions of each element, showed spectacular increases in thermal-shock resistance. The specimens from the middle of elements from Lots 51,52 , and 63 heated in High-Fire Run 5 showed the greatest resistance to thermal shock. For the Lot-52 element, this corresponded to roomtemperature thermal conductivities of $\sim 150$ $\mathrm{W} / \mathrm{m} \cdot \mathrm{K}$ (see Fig. B13). Metallography indicated that this high resistance also corresponded to excessive melting of the bore surfaces (see Figs. B10 and B11). The element from Lot 58 heated in High-Fire Run 5 showed only a moderate improvement of thermal-shock resistance. This was not consistent with the MULE data, which indicated excessive melting comparable in extent and location to that of elements from the other three lots. The ZAP test results on these three lots led to further work on Lot-52 elements, i.e., to thermal-conductivity measurements and metallography.

The elements that did not show excessive melting had very typical thernal-shock indices of $\sim 130$ to 170 , except for the highly loaded elements of Lots $54,55,59$. All samples of the latter elements from HighFire kun 7, except the G-end samples, had very low themal-shock resistances. (See Fig. B12 for correlation with metallography.)

The general trend was that 30-volscarbide materials were more resistant to thermal shock than 35-volo-carbide materials. Wo correlation with flour type was found. For eiements with medium loadings that did not show excessive melting, it did not seem to make much difference whether the elements from a given lot had been high-fired or lowfired (see elements in Lots 50, 53, and 62). Thus, for these elements, thermal conductivity did not appear to affect the $\mathrm{zAP}$ test results. The situation appears to be different, however, for elements with high loadings (see Lots 54, 55, and 59). 
TABLE BX

SUMMARY OF THERMAL-SHOCK RESULTS FOR COMPOSITE ELEMENTS OF THE NF-1 EXPERIMENT

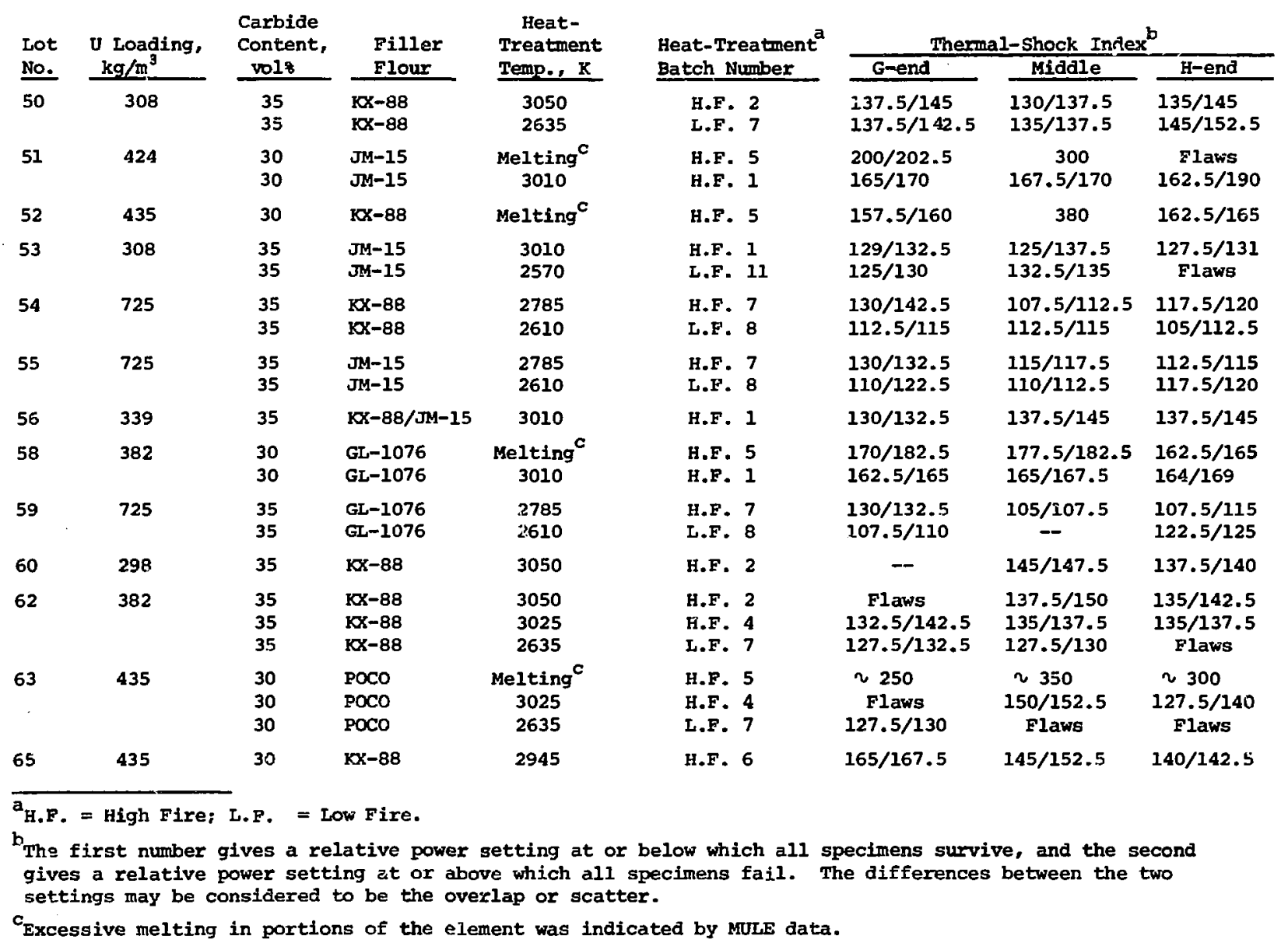

\section{F. Thermal-Stress Resistance (Peak-Power Density Test)}

A number of uncoated composite elements in the machined, high-fired condition were tested for thermal-stress resistance by means of a modified peak-power density test. * This test attempts to match the thermal stress, calculated for a specimen tested in the thermal-stress apparatus, to the axial peak-power density of a nuclear propulsionreactor fuel element. This was achieved by reducing the diameter of the sonic-flow nozzles in the six corner holes of a $356-\mathrm{mm}-$ long fuel-element specimen, which makes it possible to duplicate (at a single point in the experimental power ramp) the power den${ }^{\star}$ See Ref. A4 of Appendix A. density, temperature, and thermal stress of a reactor element at full-power steadystace operating condition. The test procedure was designed to permit the evaluation of relative thermal-stress resistances of single elements from individual development and reactric prodiction extrusion lots. The various uncoated specimens were compared on the basis of the relative power density attained at failure. The performance relative to reactor operating conditions was measured with respect to the peak reactor axial power denstty of $\sim 4100 \mathrm{MW} / \mathrm{m}^{3}$. 
For assigned values of thermal conductivity ${ }^{\star}$ and a test flow rate of $0.0177 \mathrm{~kg} / \mathrm{s} \mathrm{H}_{2}$, this power density correspond; to a test temperature of $1795 \mathrm{~K}$ and to $\mathrm{a} \Delta \mathrm{T}=\overline{\mathrm{T}}-\mathrm{T}_{\min }=80 \mathrm{~K}$, where $\bar{T}$ is the calculated mean matrix crosssection temperature and $T_{\min }$ is the minimum temperature a.t the surface of the corner coolant hole. For material of higher thermal conductivity, higher power densities and test temperatures are reached before this $\Delta T$ is exceeced.

Table BXI shows performances of composite matrices and of various comparison materials in the above test. Most important, the results show that 35-volo-carbide matrices with good thermal stress resistance (q') > $4100 \mathrm{MW} / \mathrm{m}$ in this test) in the uncoated condition were made from $\mathrm{kx}-88$ or JM-15 filler flours, provided that the thermal conductivity was high enough. All composite elements except the Lot-54 element from High-Fire Run 7 showed generally better thermal-stress resistance than the IAsLproduced AXM graphite element containing pyrocarbon-coated $\mathrm{UC}_{2}$ particles.

The s-97, 30-volo-carbide element from Lot 68 gave extrenely uniform, high values of $\mathrm{q}^{\prime \prime \prime}\left(\sim 6200 \mathrm{MW} / \mathrm{m}^{3}\right)$ at fracture. The thermal conductivity at the $\mathrm{H}$-end was $61 \mathrm{~W} / \mathrm{m} \cdot \mathrm{K}$. The GL-1074, 30-volo-carbide element from WANL Lot 8 had a high thermal-stress resistance. This element essentially had the matrix target structure at all stations.

The $\mathrm{kx}-88$, 30-volf-carbide elements of Lot 65 gave variable results. The values of q"' at fracture from this lot were consistent with the fact that the G-end of the element had been hotter than the rest of the element and had a thermal conductivity of $93 \mathrm{w} / \mathrm{m} . \mathrm{K}$. However, another element from this lot had a low value of $q^{\prime \prime \prime}$ at fracture at the G-end.

\footnotetext{
* $A$ value of $74 \mathrm{~W} / \mathrm{m} \cdot \mathrm{K}$ for room-temperature thermal conductivity was used in the analysis. A standard temperature dependence of conductivity was used which reduced this value to $39 \mathrm{~W} / \mathrm{m} \cdot \mathrm{K}$ at $1795 \mathrm{~K}$.
}

The RX-88, 35-voli-carbide elenents showed increasing thermal-stress resistance that correlated well with the degree to winich the target structure was approached and the thermal conductivity increased. The low values of $\mathrm{q}^{\prime \prime \prime}$ at fracture for the pieces of the Lot-54 element were consistent with inadequate firing in High-Fire Run $7(\lambda=49$ $W / m \cdot K$ at the $H$-end), and the order of the $q^{\prime \prime \prime}$ values were consistent with the fact that the G-end was the hottest. The q"'-values for the pieces of the Lot-62 element from High-Fire Run 4 were consistent with the fact that the G-end was the hottest. The performances of the pieces from the elements of Lots 50 and 60 from high-Fire Rur 2 were very similar, except for the middle piece of the Lot-60 element that had not fractured when the test was taken off line at $q^{\prime \prime \prime}>$ $6900 \mathrm{MW} / \mathrm{m}^{3}$. The order of the values of $\mathrm{q}^{\prime \prime \prime}$ at fracture for the pieces of the Lot-62 element from High-Fjre Run 2 was inverted from that expected on the basis of MULE-data evidence that the $H$-end was hottest.

Both the JM-15, 35-voli-carbide element of Lot 53 and the JM-15/KX-88, 35-yolz-carbide element of Lot 56 generally showed q"'values similar to those for the $\mathrm{KX}-88$, 35volf-carbide element of Lot 62 from HighFire Run 4, which likewise had not been heated above the solidus temperature. The G-end piece showing the lowest value for the Lot-53 elemert is consistent with the fact that the G-end was coldest in High-Fire 1 , but the G-end piece showing the highest value for the Lot-56 element from the same high firing is anomalous.

Elements showing thermal-stress performance for the three pieces that were neither consistent with their IPDE and MULE data nor with metallographic data on sister elements, were examined further. Metallographic examinations were madie on each of these thermal-stress pieces to complement the metallographic data obtained on sister elements. 
TABLE BXI

THERMAL-STRESS RESISTANCE TEST RESULTS ON UNCOATED COMPOS ITE ELEMENTS

\begin{tabular}{|c|c|c|c|c|c|}
\hline $\begin{array}{l}\text { Extrusion } \\
\text { Lot } \\
\end{array}$ & $\begin{array}{l}\text { Filler } \\
\text { Flour }\end{array}$ & $\begin{array}{l}\text { Carbide } \\
\text { Content, } \\
\text { yolis } \\
\end{array}$ & $\begin{array}{l}\text { CTE }(293-2300 \mathrm{k}) \text {, } \\
\mathrm{Lm} / \mathrm{m} \cdot \mathrm{K}\end{array}$ & $\begin{array}{c}\text { Room-Temperature } \\
\text { Thirmal Cond., } \\
W / m \cdot K\end{array}$ & $\begin{array}{c}\text { Fracture Power Density, } \\
\mathrm{MW} / \mathrm{m}^{3}\end{array}$ \\
\hline 17 & $\operatorname{AXM}$ & Graphite $e^{b}$ & 5.6 & -.-- & $4050 \mathrm{G}, 4500 \mathrm{M}, 4500$ \\
\hline $8^{c}$ & GL-1074 & 30 & 6.6 & $75 \mathrm{H}$ & $62006,5500 \mathrm{M},>6300 \mathrm{H}$ \\
\hline 68 & $5-97$ & 30 & 6.1 & $61 \mathrm{H}$ & $6600 G, M, H$ \\
\hline 65 & $\mathrm{kX}-88$ & 30 & 6.5 & $62 M, H$ & $4300 \mathrm{G}, 4700 \mathrm{M}, 5500 \mathrm{H}$ \\
\hline 65 & $x x-88$ & 30 & 6.5 & $93 \mathrm{G}, 68 \mathrm{H}$ & $>6700 \mathrm{G}, 5100 \mathrm{M}, 5300 \mathrm{H}$ \\
\hline 713 & s-97 & 35 & 6.3 & $50 G, M, H$ & $4700 \mathrm{G},>6200 \mathrm{M},>5300 \mathrm{H}$ \\
\hline 54 & $\mathrm{kX}-88$ & 35 & 7.0 & $49 M, H$ & $4000 \mathrm{G}, 3700 \mathrm{M}, 3500 \mathrm{H}$ \\
\hline 62 & $1 \times x-88$ & 35 & 6.6 & $72 M, H$ & $5200 G, 5100 \mathrm{M}, 4400 \mathrm{H}$ \\
\hline 60 & $K x-88$ & 35 & 6.6 & $85 \mathrm{M}, \mathrm{H}$ & $5000 \mathrm{G},>6900 \mathrm{M}, 5300 \mathrm{H}$ \\
\hline 50 & $\mathrm{kx}-88$ & 3.5 & 6.8 & $81 \mathrm{M}, \mathrm{H}$ & $5400 \mathrm{G}, 5300 \mathrm{M}, 5200 \mathrm{H}$ \\
\hline 62 & $k x-88$ & 35 & 6.8 & $87 \mathrm{M}, \mathrm{H}$ & $6800 G, 6000 M, 5800 \mathrm{H}$ \\
\hline 53 & $\mathrm{JM}-15$ & 35 & 6.7 & $75 M, \mathrm{H}$ & $3700 \mathrm{G}, 5200 \mathrm{M}, 5000 \mathrm{H}$ \\
\hline 56 & $J M-15 / K X-88$ & 35 & 6.7 & $76 \mathrm{M}, \mathrm{H}$ & $5100 G, 4600 \mathrm{M}, 4800 \mathrm{H}$ \\
\hline
\end{tabular}

Again, the metallographic data offered no explanation for the anomalous $q^{\prime \prime \prime}$-values. Flaws in the matrix, not revealed in inspection, coild have been present leading to the anomalous results.

\section{APPLICATION OF ZRC COATINGS *}

The surfaces of the coolant channels and all external surfaces of the composite elements were protected with a zrC carbide coating deposited by a chemical-vapor-deposition (CVD) process. This coating was expected to prevent or limit the chemical reaction of hot hydrogen with the carbon of the fuel-element matrix. In preparation for the application of the carbide coating the external surfaces of the fuel elements were machined to the specified dimensions ( 219.1 mm across flats). The coolant channels were not machined but were extruded to $~ 2.59 \mathrm{~mm}$ ciam.

*This section presents a general discussion of the ZrC coating conditions used for NF-1 elements.
The overall CVD reaction may be represented by the equation

$$
\mathrm{ZrCl}_{4}(g)+\mathrm{CH}_{4}(g)=\operatorname{ZrC}(\mathrm{s})+4 \mathrm{HCl}(g) .
$$

This thermodynamic relation not only establishes the lower bound for the coating-gas composition, but also serves as the basis for mass-balance calculations along the axial length of the fuel elements. It also suggests that the partial pressure of $\mathrm{HCl}(\mathrm{g})$ will have a strong effect on the deposition rate. Consequently, the reduction of $\mathrm{Z}_{-} \mathrm{Cl}_{4}(\mathrm{~g})$ in the system must be considered:

$$
\mathrm{zrCl}_{4}(\mathrm{~g})+1 / 2 \mathrm{H}_{2}(\mathrm{~g})=\mathrm{ZrCl}_{3}(g)+\mathrm{HCl}(\mathrm{g})
$$

and

$$
\operatorname{ZrCl}_{3}(g)+1 / 2 \mathrm{H}_{2}(g)=\mathrm{ZrCl}_{2}(g)+\mathrm{HCl}(g) .
$$

The reduction reaction is important near the coating-gas inlet end of the elements 
because it determines the quantity of HCl formed, which strongly affects the initial deposition rate. The quantities affecting the deposition, which can be calculated from the above thermodynamic relations, and appropriate mass-balanse equations as function of axial position along the element are: $\mathrm{P}_{\text {Salt }}{ }^{- \text {sum }}$ of partial pressures of $\mathrm{ZrCl}_{4}(g), \mathrm{ZrCl}_{3}(g)$, and $\mathrm{ZrCl}_{2}(g) ; \mathbf{P}_{\mathrm{CH}_{4}}{ }^{--}$ partial pressure of methane; $\mathrm{P}_{\mathrm{HCl}}$--partial pressure of hydrogen chloride; and $\mathrm{P}_{\mathrm{H}_{2}}$ partial pressure of hydrogen. An analytical calculational program was used to understand the variables affecting the deposition conditions.

The general deposition conditions used in coating the composite elements are listed in Table BXII. Inspection and evaluation proceduies for evaluating the coatings included: high-resolution-eddy-current examination for the detection of cracks, MULE examination for mass of coating deposited vs length of fuel element, $x$-ray diffraction analysis for the determination of lattice parameter, chemical analysis for impurities such as $\mathrm{Cl}_{2}$ and $\mathrm{O}_{2}$, microstructure determination by optical and scanning-electron microscope, determination of coefficient of thermal expansion, and determination of the effectiveness of the coating as a protective leyer in a component test that simulated conditions in a nuclear propulsion reactor.
TABLE BXII

PROCESS CONDITIONS FOR DFPOSITION OF ZrC COATING IN THE COOLANT CHANNELS OF A COMPOSITE FUEL ELEMEN'P

(A) Initial Composition of Coating Gas

\section{Constituents}

$\mathrm{ZrCl}_{4}$

$\mathrm{CH}_{4}$

$\mathrm{H}_{2}$

Ar

$\mathrm{HCl}$ (first $20 \mathrm{~h}$ )

HCl (last $5 \mathrm{~h}$ )

$$
\text { Flow/Element, a }
$$$$
\mathrm{m}^{3} / \mathrm{s} \text { (STP) }
$$$$
1.2 \times 10^{-6}
$$$$
0.9
$$

66

66

2.6

0
(B) Deposition Temperature and Coating Thickness

\begin{tabular}{|c|c|c|}
\hline $\begin{array}{c}\text { Station from } \\
\text { Inlet End, } \\
\text { mm }\end{array}$ & $\begin{array}{c}\text { Deposition } \\
\text { Temp., } \\
\mathrm{K} \\
\end{array}$ & $\begin{array}{c}\text { Zrc coating } \\
\text { Thickness. } \\
\mu \mathrm{m} \\
\end{array}$ \\
\hline 127 & 1525 & 60 \\
\hline 254 & 1540 & 89 \\
\hline 508 & 1580 & 119 \\
\hline 762 & 1615 & 132 \\
\hline 1012 & 1640 & 135 \\
\hline 1270 & 1660 & 132 \\
\hline
\end{tabular}

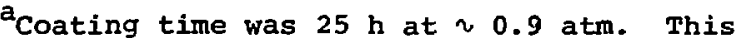
flow of gas was coating the channel surfaces of one element $\left(0.235 \mathrm{~m}^{2}\right.$ of surface area).

\section{ACKNOWLEDGMENTS}

R. Bard and A. Driesner deserve recognition for their efforts in organizing and managing the complex details of the NF-1 composite element experiment. 


\section{APPENDIX C}

\section{PROPERTIES OF (U,2r)C-GRAPHITE (COMPOSITE) FUEL ELEMENTS}

\section{INTRODUC'PION}

This appendix presents the available property data for $(U, \mathrm{Zr}) \mathrm{C}$-graphite fuel elements. The data are presented in a series of tables and figures; comments are made in the text, only where required.

\section{CHEMICAL CONTENT AND DENSITY}

Table cI presents chemical-composition and density data for composite fuel elements of $\sim 70 \mathrm{~kg} / \mathrm{m}^{3}$ uranium loading at 15,20 , and 30-vol: carbide contents. Table CII presents similar data for elements of $\sim 435$ $\mathrm{kg} / \mathrm{m}^{3}$ uranium loading at $30 \mathrm{~m}, 35 \mathrm{n}, 40 \mathrm{~m}$ and 45-voli carbide contents.

\section{MECHANICAI PROPERTIES}

Table cIII presents room-temperature flexural, compressive, and tensile-strength data for composite fuel elements of 10 to 50-volis carbide content.

Tablc CIV gives room-temperature elastic-modulus data, longitudinal and transverse to the extrusion direction, for composite materials of 10-to 50-voli carbide content. Table CV presents the temperature dependence of el.astic modulus for 30- and 35-vol8 carbide-content composite materials.

stress-strain properties of composite materials are given in Table CVI and Fig. $\mathrm{Cl}$.

Compressive-deformation information, for the longitudinal orientation, is given in Table cVII for composites of 10- to 50vols carbide content at temperatures from 2773 to $2973 \mathrm{~K}$.
TABLE CI

CHERICAI CONTENT AND DENSITY OF (U, Zr) C-GRAPHITE (COMPOSITE) FUEL ELEMENTS (URANIUM IOADING, $\left.\sim 70 \mathrm{~kg} / \mathrm{m}^{3}\right)$

\begin{tabular}{|c|c|c|c|}
\hline \multirow[b]{2}{*}{ Parametex } & \multicolumn{3}{|c|}{ Nominal Carbide Content, volz } \\
\hline & $15^{\mathrm{a}}$ & 20 & 30 \\
\hline Gross density, $\mathrm{Ng} / \mathrm{m}^{3}$ & 2.62 & 2.82 & 3.26 \\
\hline zirconium, wto & 34.0 & 40.7 & 52.9 \\
\hline $\mathrm{Mg} / \mathrm{m}^{3}$ & 0.89 & 1.15 & 1.72 \\
\hline Uranium, wt8 & 2.7 & 2.58 & 2.22 \\
\hline $\mathrm{Mg} / \mathrm{m}^{3}$ & 70.0 & 72.8 & 72.4 \\
\hline Carbon, wt: & 63.3 & 56.4 & 44.8 \\
\hline $\mathrm{Mg} / \mathrm{m}^{3}$ & 1.66 & 1.59 & 1.46 \\
\hline Cariolde, volt $z^{b}$ & 15.0 & 20.2 & 30.1 \\
\hline Carbon, volsb & 73.3 & 68.4 & 58.6 \\
\hline Voids, vols ${ }^{b}$ & 11.7 & 11.4 & 11.3 \\
\hline $\mathrm{zrC}$, wto & 38.4 & 46.1 & 59.7 \\
\hline UC, wt: & 2.8 & 2.7 & 2.4 \\
\hline Free C, wto & 58.8 & 59.9 & 37.7 \\
\hline $\begin{array}{l}\text { Estimated. } \\
\text { b The density of carbo } \\
\text { be } 2.1 \mathrm{Mg} / \mathrm{m}^{3} \text { rather } \\
\text { crystalline graphite } \\
\text { UC } 0.97 \text { were assumed } \\
\text { respectively. The d } \\
\text { assumed to be propor } \\
\text { the carbide constitu }\end{array}$ & $\begin{array}{l}\text { in a c } \\
\text { ian the } \\
\text { The d } \\
\text { be } 6 . \\
\text { sity of } \\
\text { onal to } \\
\text { its. }\end{array}$ & $\begin{array}{l}\text { ite wa } \\
\text { les of } \\
\text { les } 13.6 \\
(\mathrm{zr}) \mathrm{C}_{0} \\
\text { mole }\end{array}$ & $\begin{array}{l}\text { urned to } \\
\text { ior } \\
\frac{97}{3} \text { and } \\
\text { ion of }\end{array}$ \\
\hline
\end{tabular}

\section{THERMAL PROPERTIES}

Table CVIII presents thermal-conductivity data for ATJ-S graphite, ZrC carbide, and two $(\mathrm{U}, \mathrm{Zr}) \mathrm{C}$-graphite composites. The data for composite $A$ in Tabie cVIII represent the thermal conductivity-vs-temperature relationship for a 30 - or 35-voli carbidecontent composite that had been heat-treated at temperatures below the solidus line (see Fig. 3 of main body of report). The data 
TABIE CII

CHEMICAL CONTENT AND DENSITY OF (U,Zr) CGRAPHITE (COMPOSITE) FUEL ELEMENTS (URANIUM LOADING, $435 \mathrm{~kg} / \mathrm{m}^{3}$ )

\begin{tabular}{|c|c|c|c|c|}
\hline \multirow[b]{2}{*}{ Parameter } & \multicolumn{2}{|c|}{ Nominal Carblde } & \multicolumn{2}{|c|}{ Content, } \\
\hline & 30 & 35 & 40 & 45 \\
\hline Gross density, $\mathrm{Mg} / \mathrm{m}^{\mathrm{g}}$ & 3.36 & 3.59 & 3.87 & 4.09 \\
\hline zirconium, wto & 46.6 & 51.0 & 56.0 & 59.7 \\
\hline $\mathrm{Kg} / \mathrm{m}^{9}$ & 1.56 & 1.83 & 2.17 & 2.44 \\
\hline Orasium, wto & 12.50 & 12.02 & 11.22 & 10.65 \\
\hline $\mathrm{kg} / \mathrm{m}^{3}$ & 420 & 431 & 435 & 436 \\
\hline Carbon, wto & 40.5 & 36.5 & 32.6 & 29.2 \\
\hline $\mathrm{Mg} / \mathrm{m}^{3}$ & 1.36 & 1.31 & 1.26 & 1.20 \\
\hline Carblde, voli ${ }^{\mathrm{a}}$ & 30.5 & 35.2 & 41.0 & 45.5 \\
\hline Carbon, voli ${ }^{\mathrm{a}}$ & 54.0 & 49.8 & 45.5 & 40.5 \\
\hline Voids, volsa & 15.5 & 15.0 & 13.5 & 14.0 \\
\hline ZrC, wto & 52.7 & 57.7 & 63.4 & 67.6 \\
\hline uC, wtr & 13.1 & 12.6 & 11.8 & 11.2 \\
\hline Free $C$, wt: & 33.7 & 29.2 & 24.7 & 20.8 \\
\hline
\end{tabular}

The density of carbon in a composite was assumed to be $2.1 \mathrm{Mg} / \mathrm{m}^{3}$ rather than the value of 2.26 for crystalline graphite. The densities of $2 \mathrm{CC}_{\mathrm{C}} .97$ and $\mathrm{UC}_{0.97}$ were assumed to be 6.59 and $13.60 \mathrm{Mg} / \mathrm{m}^{3}$ ? respectively. The density of $\left(\mathrm{U}, \mathrm{Zr}_{\mathrm{r}} \mathrm{C}_{0.97} 97\right.$ was assumed to be proportional to the mole fraction of the carbide constituents.

\section{TABLE CIII}

ROOM TEMPEPATURE FLEXURAL, COMPRESSTVE, AND TENSILE FRACTURE STRENGTHS OF $(U, 2 I) C-$ GRAPHITE FUEL ELEMENTS

\begin{tabular}{|c|c|c|c|}
\hline \multirow{2}{*}{$\begin{array}{l}\text { Carbide } \\
\text { Content, } \\
\text { vols } \\
\end{array}$} & \multicolumn{3}{|c|}{ Strength, a MPa } \\
\hline & Flexural & Compressive & Tensile \\
\hline 10 & $44.8 \pm 2.7$ & $74.5 \pm 0.7$ & 35 \\
\hline 20 & $47.9 \pm 1.4$ & $97.6 \pm 1.8$ & 43 \\
\hline 25 & $63.4 \pm 5.1$ & $109.5 \pm 12.4$ & 49 \\
\hline 30 & $53.0 \pm 1.6$ & $118.1 \pm 10.3$ & 39 \\
\hline 50 & $65.6 \pm 2.3$ & $>290$ & 68 \\
\hline $\begin{array}{l}\text { Pewee-1 } \\
\text { graphite } \\
\text { elements }\end{array}$ & $35.0 \pm 3.4$ & $85.3 \pm 4.3$ & -- \\
\hline
\end{tabular}

Average of at least three samples. Samples were of full cross section, $\sim 19 \mathrm{~mm}$ across flats. The flexural and tensile strengths were transverse to the extrusion direction and the compressive strengths were parallel to the extrusion afrection.

\section{TABLE CIV}

ROOM-TEMPERATURE ELASTIC MODULUS OF $(\mathrm{J}, \mathrm{zr}) \mathrm{C}$-GRAPHITE COMPOSITES

\begin{tabular}{|c|c|c|c|}
\hline $\begin{array}{l}\text { Carbide } \\
\text { Content, } \\
\text { voli }\end{array}$ & $\begin{array}{l}\text { Longitudinal } \\
\text { Elastie } \\
\text { Modulus, a } \\
\text { GPa } \\
\end{array}$ & $\begin{array}{l}\text { Transverse } \\
\text { Effective } \\
\text { Elastic } \\
\text { Modulus, } \\
\text { GPa }\end{array}$ & $\begin{array}{l}\text { Modulus Ratio } \\
\text { Long./Trans. }\end{array}$ \\
\hline 10 & 17.6 & 5.9 & 3.0 \\
\hline 20 & 25.4 & 7.9 & 3.2 \\
\hline 25 & 30.3 & 9.6 & 3.2 \\
\hline 30 & 42.0 & 11.8 & 3.6 \\
\hline 50 & 108.0 & 44.0 & 2.5 \\
\hline
\end{tabular}

TABLE CV

\begin{tabular}{|c|c|c|}
\hline \multirow[b]{3}{*}{ Temperature, $x$} & \multicolumn{2}{|c|}{$\begin{array}{l}\text { DE DEPENDENCE OF ELASTIC } \\
\text { OF (U, Zr) C-GRAPHITE } \\
\text { FUEL ELEMENTS }\end{array}$} \\
\hline & \multicolumn{2}{|c|}{ Reduced ModuIus ${ }^{a}$} \\
\hline & $\begin{array}{l}30 \text {-roll } \\
\text { Carbide }\end{array}$ & $\begin{array}{l}\text { 35-voli } \\
\text { Carbide }\end{array}$ \\
\hline 300 & $1.0(35 \mathrm{GPa})$ & $1.0(44 \mathrm{GFa}$ \\
\hline 500 & 1.0 & 1.0 \\
\hline 1000 & 1.05 & 1.03 \\
\hline 1250 & 1.11 & 1.08 \\
\hline 1500 & 1.18 & 1.14 \\
\hline 2000 & 1.29 & 1.26 \\
\hline 2250 & 1.28 & 1.23 \\
\hline 2500 & 1.18 & 1.08 \\
\hline 2750 & 1.03 & 0.81 \\
\hline
\end{tabular}

Quranium loading, $166 \mathrm{~kg} / \mathrm{m}^{3}$.

for Composite $B$ in Table cvIII represent about the highest thermal conductivity that can be achieved (optimum heat-treatment conditions) for a 30- or 35-vols carbide-content composite that still retains desirable mechanical properties.

Table CIX presents typical thermal-expansion data for a 35-vols carbide-content composite haying a CTE of $6.7 \mu \mathrm{m} / \mathrm{m} \cdot \mathrm{K}$ for the 293 to 2300 temperature range. 


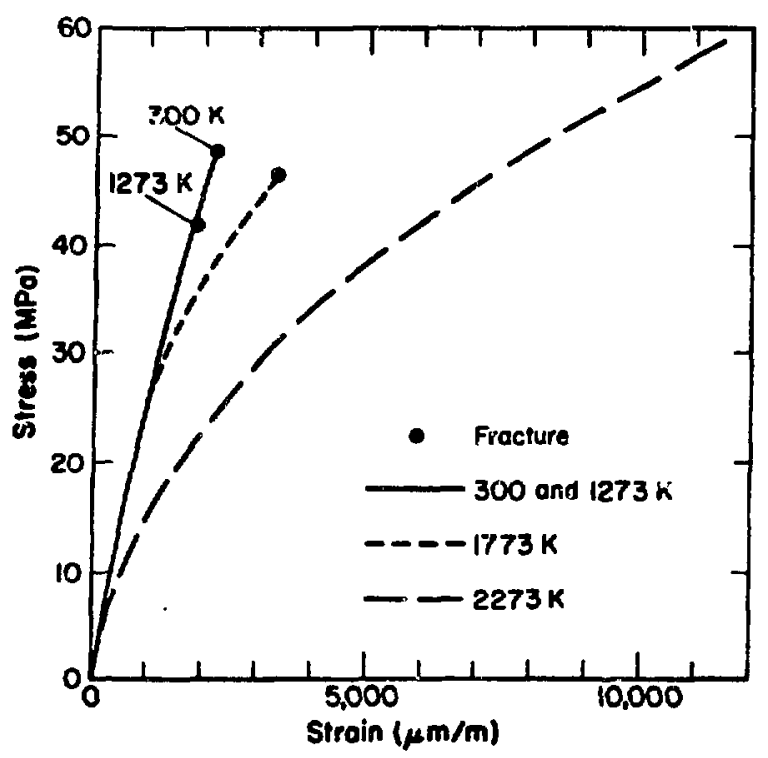

Fig. Cl. stress-strain data from room temperature to $2273 \mathrm{~K}$ for a $(\mathrm{U}, \mathrm{Zr}) \mathrm{C}$ graphite composite of 30 -vols carbide content and $63 \mathrm{C} \mathrm{kg} / \mathrm{m}^{3}$ uranium loading.

\section{TABLE CVI}

\begin{tabular}{c} 
ROOM-TEMPERATURE STRESS-STRAIN \\
PROPERTIES FOR (U, 2r) C- \\
GRAPHITE COMPOSITES \\
\hline
\end{tabular}

\begin{tabular}{|c|c|c|c|}
\hline $\begin{array}{l}\text { Carbide } \\
\text { Content, } \\
\text { yoli }\end{array}$ & $\begin{array}{c}\text { Zero Stress } \\
\text { Modulus, } \\
\text { GPa } \\
\end{array}$ & $\begin{array}{c}\text { Fallure } \\
\text { Strain, } \\
m / m \\
\end{array}$ & $\begin{array}{c}\text { Eallure } \\
\text { Stress, } \\
\text { MPa } \\
\end{array}$ \\
\hline 10 & 20 & 3900 & 38 \\
\hline 20 & 27 & 3000 & 40 \\
\hline 25 & 31 & 1600 & 35 \\
\hline 30 & 37 & 1800 & 44 \\
\hline 30 & 37 & 1500 & 42 \\
\hline 35 & 44 & 1500 & 39 \\
\hline 35 & 40 & 1000 & 26 \\
\hline 40 & 68 & 500 & 32 \\
\hline 40 & 54 & 1100 & 48 \\
\hline 50 & 57 & 1500 & 61 \\
\hline 50 & 100 & 1000 & 84 \\
\hline
\end{tabular}

Table CX preesnts $c_{p}$ data for $\mathrm{zrc}$, UC, and carbon. To obtain $C_{p}$ for a composite, multiply the appropriate component by the corresponding mass fraction (obtain chemicalanaiyais data from Tables $\mathrm{CI}$ and CII) "To obtain $0 . C_{p^{\prime}}$ use the $\Delta L / L$ data from Table CIX
TABLE CVII

COMPRESSIVE DEFORMATION OF $(\mathrm{U}, \mathrm{Zr})$ C-GRAPHITE (COMPOSITE) ELEMENTS SUBJECTED TO $3.45 \mathrm{MPa}$ FOR ONE YOUR

\begin{tabular}{|c|c|c|c|c|c|}
\hline \multirow{2}{*}{$\begin{array}{l}\text { Carbide } \\
\text { Content, } \\
\text { voli }\end{array}$} & \multirow{2}{*}{$\begin{array}{l}\text { Uranium } \\
\text { Loading, } \\
\mathrm{kg} / \mathrm{m}^{3}\end{array}$} & \multicolumn{4}{|c|}{ Compressive Deformation, $\&$} \\
\hline & & $2773 \mathrm{~K}$ & $2873 \mathrm{~K}$ & $2923 \mathrm{~K}$ & $2973 \mathrm{~K}$ \\
\hline 10 & 300 & 0.22 & 0.21 & 0.26 & 0.20 \\
\hline 20 & 300 & 0.43 & 1.02 & 1.08 & 1.10 \\
\hline 25 & 300 & 0.37 & 0.50 & 0.59 & 0.61 \\
\hline 30 & 300 & 0.72 & 0.98 & 2.45 & 2.35 \\
\hline 30 & 500 & 0.41 & 0.43 & --- & $--\infty$ \\
\hline 40 & 500 & 0.76 & 0.87 & --- & $-\infty$ \\
\hline 50 & 300 & 0.8 & 3.1 & 5.1 & 11.1 \\
\hline 50 & 500 & 2.5 & 2.6 & $\ldots$ & $-\infty$ \\
\hline
\end{tabular}

\section{TABLE CVIII}

THERMAL CONDUCTIVITY OF ATJ-S GEAPHITE, ZrC CARBIDE AND TWO (U,Zr)CGRAPHITE COMPOSITES

\begin{tabular}{|c|c|c|c|c|}
\hline \multirow[b]{2}{*}{$\begin{array}{c}\text { Temperature, } \\
\mathbf{K}\end{array}$} & \multicolumn{4}{|c|}{ Thermal Conductivity, $\mathrm{H} / \mathrm{m} \cdot \mathrm{K}$} \\
\hline & $\begin{array}{l}\text { Composite } \\
\mathrm{A} \\
\end{array}$ & $\begin{array}{c}\text { Composite } \\
\text { B } \\
\end{array}$ & ATJ-S & $\underline{\operatorname{zrc}}$ \\
\hline 300 & 52 & 90 & 125 & 19 \\
\hline 400 & 49 & 71 & 110 & 20 \\
\hline 500 & 46 & 60 & 97 & 20.5 \\
\hline 600 & 43 & 53 & 86 & 21 \\
\hline 700 & 40 & 48 & 78 & 21.5 \\
\hline 800 & 38 & 44 & 72 & 22 \\
\hline 1000 & 34 & 38 & 60 & 23.5 \\
\hline 1200 & 32 & 36 & 52 & 25 \\
\hline $140 \mathrm{C}$ & 30 & 30 & 45 & 27 \\
\hline 1600 & 30 & 30 & 41 & 29 \\
\hline 1800 & 30 & 30 & 38 & 31 \\
\hline 2000 & 30 & 30 & 35 & 33 \\
\hline 2200 & 30 & 30 & 33 & 35 \\
\hline 2400 & 30 & 30 & 32 & 36 \\
\hline 2600 & 30 & 30 & 30 & 38 \\
\hline
\end{tabular}

to calculate the dependence of $\rho$ on temperature, 1.e.,

$$
\rho_{T}=\rho_{A}(1+\Delta L / L)^{-3}
$$

where $P_{T}$ is the density at temperature $T: D_{A}$ is the density at ambient temperature from Tables CI and CII; and $\Delta \mathrm{L} / \mathrm{L}$ is the fxactional change in linear thermal expansion from ambient to temperature $T$ from Table CIX. 
TABLE CIX

THERMAL EXPANSION PROPERTIES OF A HIGH EXPANSION (U,Zr) C-GRAPHITE (COMPOSITE) FUEL ELEMENT

$\begin{array}{ccccc}\text { Temperature, K } & \$ \Delta \mathrm{L} / \mathrm{L} & \mu \mathrm{m} / \mathrm{m} \cdot \mathrm{K} & \begin{array}{c}\text { Inst. } \\ \mu \mathrm{m} / \mathrm{m} \cdot\end{array} \\ 293 & 0.000 & 4.26 & 4.26 \\ 300 & 0.003 & 4.28 & 4.31 \\ 500 & 0.101 & 4.88 & 5.42 \\ 750 & 0.249 & 5.44 & 6.28 \\ 1000 & 0.412 & 5.83 & 6.70 \\ 1250 & 0.583 & 6.09 & 6.85 \\ 1500 & 0.756 & 6.26 & 6.88 \\ 1750 & 0.930 & 6.38 & 6.96 \\ 2000 & 1.109 & 6.50 & 7.25 \\ 2200 & 1.260 & 6.61 & 7.74 \\ 2300 & 1.340 & 6.68 & 8.10\end{array}$

TABLE CX

CALCULATION OF CP FOR $(\mathrm{U}, \mathrm{ZI}) \mathrm{C}$ GRAPHITE COMPOSITES

\begin{tabular}{|c|c|c|c|}
\hline \multirow{2}{*}{$\begin{array}{l}\text { Temperature, } \\
K\end{array}$} & \multicolumn{3}{|c|}{$w \cdot g / g \cdot k$} \\
\hline & $\operatorname{zrc}^{a}$ & $u c^{b}$ & Carbon $^{\mathrm{C}}$ \\
\hline 300 & 0.368 & 0.201 & 0.721 \\
\hline 400 & 0.430 & 0.219 & 3.03 \\
\hline 600 & 0.454 & 0.227 & 1.27 \\
\hline
\end{tabular}

$600 \quad 0.468 \quad 0.233 \quad 1.42$

$\begin{array}{llll}700 & 0.476 & 0.237 & 1.55\end{array}$

$800 \quad 0.482 \quad 0.242 \quad 1.65$

$\begin{array}{llll}900 & 0.484 & 0.245 & 1.71\end{array}$

$\begin{array}{llll}1000 & 0.486 & 0.249 & 1.76\end{array}$

$\begin{array}{llll}1200 & 0.493 & 0.257 & 1.85\end{array}$

$\begin{array}{llll}1400 & 0.498 & 0.265 & 1.93\end{array}$

$\begin{array}{llll}1600 & 0.507 & 0.275 & 1.98\end{array}$

$\begin{array}{llll}1800 & 0.520 & 0.286 & 2.03\end{array}$

$2000 \quad 0.540 \quad 0.299 \quad 2.07$

$2200 \quad 0.564 \quad 0.313 \quad 2.12$

$2400 \quad 0.592 \quad 0.328 \quad 2.14$

$2600 \quad 0.623 \quad 0.345 \quad 2.16$

$\begin{array}{llll}2800 & 0.656 & 0.363 & 2.18\end{array}$

a. K. Storms, The Refractory Carbides, 1967. b. Ibid.

C. B. Spence, "Research and Development on Advanced Graphite Materlals -. Analytical presentation of the Measurement of the speclflc Heat of Gxaphlte," WADD-TR-61-72, Vol XLI, Nat. Carbon Co., Parma, OH, July 1963. 


\section{APPENDIX D}

\section{STABILITY OF (U,Zr)C-GRAPHITE FUEL ELEMENTS}

\section{INTRODUCTION}

An experiment was conducted at I.ASL to ascertain the effect of storage for periods of time up to two years on $(U, \mathrm{zr}) \mathrm{C}$-graphite (composite) fuel elements. Depending upon process conditions and uranium loading, small quantities of both $\mathrm{UC}_{2}$ and $(U, \mathrm{Zr}) \mathrm{C}$ solid solution of relatively high uranium mole percent could be present in some composite elements. The hydrolysis of $\mathrm{UC}_{2}$ with moisture in air is rapid, but little is known about the stability of $(U, \mathrm{Zr}) \mathrm{C}$ solid solutions. Two storage conditions were used in these studies: (1) in air of 908 relative humidity and $310 \mathrm{~K}$ temperature, and (2) in nitrogen of very low relative humidity at ambient temperature. The elements were evaluated before and after storage for changes in electrical resistance, dimensions, number of cracks in ZrC coolant-channel coating, mass, carbide microstructure, and performance in a hydrogen corrosion test.

\section{RESULTS OF STORAGE EXPERIMENT}

The (U,Zr)C-graphite elements used in the experiments had a carbide content of 30 vols and uranium loadings of 125 and 500 $\mathrm{kg} / \mathrm{m}^{3},--2.8$ and 11 mole percent $\mathrm{UC}$ in the solid solution, respectively.

After 77 days of storage, no significant changes were observed in the elements stored in either the wet or dry rondition.

The results of the evaluation of elements stored for 6 and 12 months are given in Table DI. Because there were no significant differences between the results obtained with elements of different uranium loading, the data given are averages of
TABLE DI

CHANGES IN (U,2r)C-GRAPHITE FUEL ELEMENTS AFTER STORAGE FOR 6 AND 12 MONTHS

\begin{tabular}{|c|c|c|c|c|}
\hline \multirow[b]{2}{*}{ Parameter } & \multicolumn{2}{|c|}{ Dry storage ${ }^{a}$} & \multicolumn{2}{|c|}{ Wet storage ${ }^{b}$} \\
\hline & 6 Mos. & 12 Mos. & 6 Mos. & 12 Mos. \\
\hline $\begin{array}{l}\text { Electrical } \\
\text { resistance, \& }\end{array}$ & -0.6 & -0.2 & +1.9 & +2.4 \\
\hline Mass change, * & 0.0 & 0.0 & +0.4 & +0.5 \\
\hline $\begin{array}{l}\text { Dimensional } \\
\text { change across } \\
\text { flats, \& }\end{array}$ & +0.0012 & +0.0011 & +0.0012 & +0.0016 \\
\hline
\end{tabular}

astorage at ambient temperature in nitrogen containing Linde Molecular Sieve $4 \mathrm{~A}$ desiccant.

${ }^{b}$ storage in air at $310 \mathrm{~K}$ and $90 \%$ relative humidity.

those for $a^{\text {?? }}$ elements. A very slight increase in the number of coating cracks was observed after six months for both the dry and wet storage conditions. No additional increase in the number of coating cracks was observed after 12 months storage. The slight. increase observed in the number of coating cracks probably was due to handling operations rather than to changes during słorage.

Fuel elements from the various storage conditions were evaluated for their hycirogen corrosion resistance in a component test consisting of 30 cycles of 10 min duration at maximum matrix temperatures of $\sim 2250 \mathrm{~K}$. The mass $10 s 5$ was determined after completion of the 5-h test. The mass losses were: $3.4 \mathrm{~g}$ for the control element, $4.2 \mathrm{~g}$ for the element in wet storage for six months, $2.5 \mathrm{~g}$ for the element in wet storage for 12 months, and $2.1 \mathrm{~g}$ for the element in dry storage for 12 months.

The results of these experiments indicated that the composite elements were stable over a relatively wide range of storage conditions. 


\section{(U, Zr)C (CARBIDE) FUEL ELEMENTS}

\section{INTRODUCTION}

The major difference between a $(\mathrm{U}, \mathrm{Zr}) \mathrm{C}$ all-carbide fuel element and a (U,zr)Cgraphite (composite) element is the absence of free carbon in the all-carbide element. As shown elsewhere (see Fig. 16 of main body of this report) a matrix temperature of $\sim 3200 \mathrm{~K}$ has been proposed as a possible operating condition in a nuclear propulsion reactor if the combined carbon-to-metal ratio in $(U, \mathrm{Zr}) \mathrm{C}$ is maintained between $\sim 0.88$ and $\sim 0.95$.

The all-carbide element, substoichiometric in carbon, may be able to achieve a very high operating temperature, but this advantage is offset, to some degree, by high density and very poor resistance to thermal stress. The density Jf a graphitematrix fuel element containing pyrolyticcarbon-coated $\mathrm{UC}_{2}$ spheres is $\sim 2.3 \mathrm{Mg} / \mathrm{m}^{3}$, that of a $(U, Z r) C-g r a p h i t e$ (composite) element is $\sim 3.5 \mathrm{Mg} / \mathrm{m}^{3}$, and that of a $(U, \mathrm{zr}) \mathrm{C}-$ all-carbide element is $\sim 5.5 \mathrm{Mg} / \mathrm{m}^{3}$ (all elements at $\sim 30 \mathrm{c} \mathrm{kg} / \mathrm{m}^{3}$ uranium loading).

The carbide elenents were fabricated by an extrusion process. Most of the extrusion work on carbide elements was done by using an extrusion mixture consisting of $\mathrm{zrC}, \mathrm{UO}_{2}, \mathrm{ZrO}_{2}$, graphite flour, and a thermosetting binder. The amount of carbon added in the form of $\mathrm{zrC}$, graphite, and binder was enough to react with all the oxygen in the $\mathrm{UO}_{2}$ and $\mathrm{ZrO}_{2}$, and still to leave 1 to 3 wts of free carbon in the element after high-temperature heat treatment. This amount of carbon in the fuel element was of help in the extrusion process, prevented the elements from sticking to the graphite fixtures used to support the elements during high-temperature heat treatment, aided in densification during heat treatment, and facilitated the machining of elements into a hexagonal cross section. After machining, the free carbon was removed by leaching the elements with hot, flowing hydrogen gas. The elements were then impregnated with zirconium using a modified chemical-vapordeposition process. The fuel elements were then given a final heat-treatment at $\$ 2800 \mathrm{~K}$.

\section{FABRICATION OF $(U, 2 r) C$ FUEL ELEMENTS}

The following is a description of the materials and procedures used to fabricate the carbide fuel elements. Most of the raw materials and equipment were those used in making composite fuel elements.

\section{A. Materials}

The $\operatorname{ZrC}$ powder used in the manufacture of fuel elements was reactor-grade $1<200$ ppm Hf! and had a Fisher average particle size of $3.5 \mu \mathrm{m}$. A typical analysis was 88.08 zirconium and 11.58 total carbon, $\sim 0.38$, of which was free carbon. Impurities included $0.28 \mathrm{~N}_{2}, 0.28 \mathrm{O}_{2}$, and $90 \mathrm{ppm}$ of sulfur. Metallic impurities were low, the major ones being $200 \mathrm{ppm}$ of titanium, 150 ppin of tantalum, and $100 \mathrm{ppm}$ of iron. The carbide particles were very dense and relatively equiaxed.

The enriched $\mathrm{vO}_{2}$ powder used in the fuel-element extrusion mix was produced at IASL. The powder had a Fisher average particle size of $\sim 5 \mu \mathrm{m}$. The particles were 
dense and discrete. Total metallic impurities were limited to 500 ppm, with a maximum 1 ppm of boron and $0.5 \mathrm{ppm}$ of cadmium.

The $\mathrm{ZrO}_{2}$ powder used was reactor-grade (< $200 \mathrm{ppm} \mathrm{Hf)}$ and had a Fisher average particle size of $\sim 1 \mu \mathrm{m}$. The powder contained 1500 ppm metallic impurities (mostly silicon and iron), from 0.1 to 0.5 웅 sulfur, and had a surface area of $\sim 10 \mathrm{~m}^{2} / \mathrm{g}$.

The carbon addition to the carbide extrusion mix was in the form of a fine graphite flour having a Fisher average particle size of $0.6 \mathrm{\mu m}$. This flour was obtained by grinding and classifying -200 mesh reactorgrade graphite powder. The maximum particle size was $\sim 10 \mu \mathrm{m}$. This flour contained 500-ppm ash, Inost of which was iron.

Varcum ${ }^{*} 8251$ thermosetting resin was used as the binder. Varcum is a partially polymerized furfuryl alcohol with a viscosity of $\sim 300 \mathrm{cP}$ at room temperature. The Varcum was catalyzed with $4 \mathrm{~g}$ of maleic anhydride per $100 \mathrm{~cm}^{3}$ of resin used.

\section{B. Extrusioil Formulation}

The extrusion mixture was calculated to provide 1 to 38 free carbon in the fuel elements after the first high-temperature treatment. This free carbon added strength to the elements, making them easier to process and machine. Most extrusion mixes consisted largely of $\mathrm{ZrC}$ powder with smaller amounts of $\mathrm{UO}_{2}, 2 \mathrm{ZO}_{2}$, and carbon powder bonded together with varcum binder.

The carbon powder and the carbon residue from the Varcum binder, 458 of the Varcum by weight, were used by the $\mathrm{UO}_{2}$ and $\mathrm{ZrO}_{2}$ in converting to the carbide, except for the free carbon left in the heat-treated element. The amount of $\mathrm{zrO}_{2}$ added to the extrusion mix depended upon the amount of $\mathrm{UO}_{2}$ added to the mix. As the uranium loading decreased, the $\mathrm{ZrO}_{2}$ content

\footnotetext{
*Varcum Chemical Division of Reichhold Chemicals, Inc.
}

increased. No $\mathrm{ZrO}_{2}$ was required at high uranium loadings. The extrusion mixes contained a constant oxygen content regardless of loading. The zirconium content of the extrusion mix remained constant.

Production batches, enough for 500 to $2500 \mathrm{~cm}^{3}$ of final product, were mixęd in Patterson-Kelly (P-R) twin-shell blenders. Just before being extruded, the larger batches were mixed intensively by passing them through a Hobart Mode1- 4532 2-hp meat chopper. This operation was used to homogenize, densify, and heat the extrusion mix. The mix was usually passed through the chopper twice before extrusion and once between each extrusion.

The carbide and oxide particles in the ruix --especially the ZrC particles -- tend to be angular, are hard, and make the mix very abrasive. Die wear is particularly severe where the flow of extrudate impinges on a die surface and changes direction, as on the upstream face of the plenum and at the base of the pin. However, surfaces over which the mix only slides are also worn, but to a lesser degree. These surfaces include the extrusion cylinder, ram head, feed holes, pin diameter, and the plenum near the exit end. After much experimentation, FerroTiC, a steel-bonded carbide manufactured by Sintercast, West Nyack, NY, was chosen for its ease of fabrication and very high wear resistance.

Because of bowing and twisting, it was impractical to fabricate the hexagonal fuelelement shapes. Therefore, cylindrical extrusions with an axial hole were extruded and processed, and this stock was then machined into the hexagonal fuel-element shape. The extrusions were first centerless-grcund and then diamond-milled into shape. Figure El shows the type of die used for extruding the one-hole cylindrical carbide fuelelement stock. The 40-ton press was also equipped with a rurmout table and cut-off arrangement that allowed the continuous extrusion from a chamber full of mix, usually 


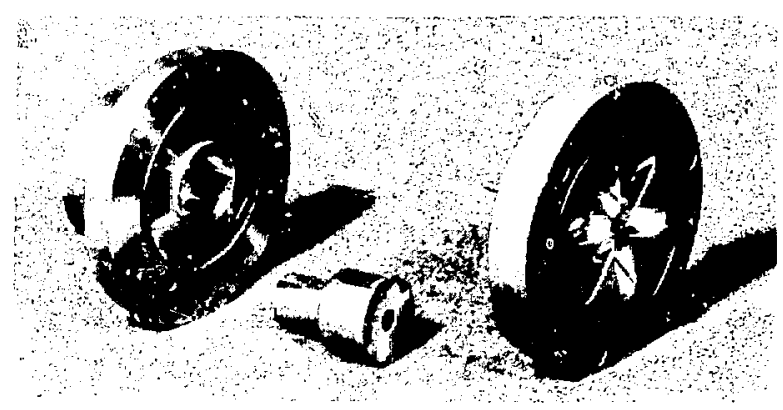

Fig. El. Extrusion die used for fabricating $(\mathrm{U}, \mathrm{Zr}) \mathrm{C}$ fuel elements.

enough for $\sim 16$ elements. The run-out table, curing fixture, and cut-off device are shown in Fig. E2.

The elements were heat-treated in electrically heated circulated-air ovens to polymerize the thermosetting resin.

The heating rate for the $90-\mathrm{h}$ cycle was $1 \%$ from 325 to $385 \mathrm{~K}, 2 \% / \mathrm{h}$ from 385 to $405 \mathrm{~K}$, and a gradual increase to a maximum of $8 \% / \mathrm{h}$ from 405 to $525 \mathrm{~K}$. The carbide excrusions were then heat-treated over a period of $54 \mathrm{~h}$ to $1125 \mathrm{~K}$ at a pressure of $\sim 10$ Torr, using an argon flush through the furnace. The products of decomposition of the Varcum binder, especially the water vapor, were sufficiently corrosive to the $\mathrm{ZrC}$ at the baking temperature to produce considerable amounts of loose $\mathrm{ZrO}_{2}$ powder on the surfaces of the extrusions. An adequate supply of argon flowing through the holes and around the outside of the extrusions diluted and swept these products away, thus considerably reducing surface oxidation.

The carbide elements were given a hightemperature heat treatment in inductionheated vertical furnaces capable of reaching temperatures up to $\approx 3000 \mathrm{~K}$. The cylindrical stock for the carbide fuel elements was held in seven-hole cassettes that were placed in holes in graphite fixtures, which, in turn, were plac sd in the vertical heat-treating furnaces. Two furnaces were used to heat-treat all elements both for low firing $(2625 \mathrm{k})$ and high firing up to $2875 \mathrm{~K}$; an argon atmo phere was used.

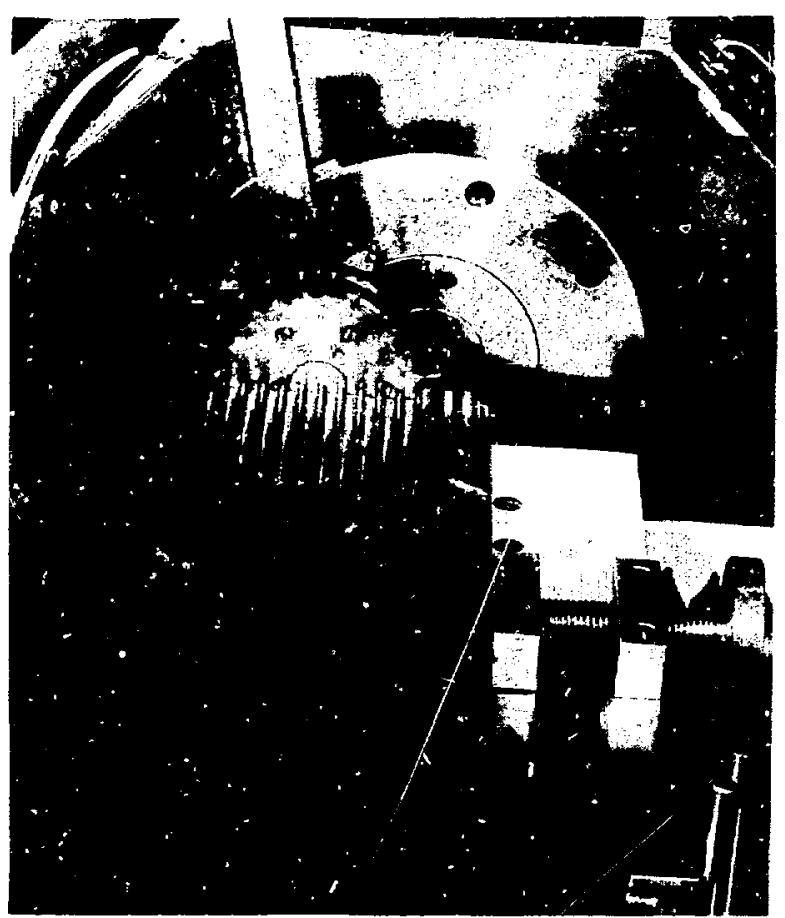

Fig. E2. Photograph of extrusion of carbide elements showing run-out table, fixture to support elements, and cut-off wheel.

The heating rate for the first high-temperature heat treatment to $2625 \mathrm{~K}$ was as follows: $2.5 \mathrm{~h}$ to $1875 \mathrm{~K}$, a 3 -h drift upward to $2625 \mathrm{~K}$ at reduced power, and a $0.5 \mathrm{~h}$ hold at $2625 \mathrm{~K}$.

During heating at the slower rate, the $\mathrm{UO}_{2}$ and $\mathrm{ZrO}_{2}$ in the extrusions reacted with the carbon surrounding the particle and were converted to carbide with the evolution of co gas. Heating at the slower rate was intended to release this gas without injuring the element.

The cassettes holding the carbide elements during the second, high-temperature, heat treatment had insertion holes that were smaller than those in the low-fire cassettes, to compensate for fuel-element shrilkage during low-fire heat treatment.

The heating rate for the second, hightemperature, treatment was $3 \mathrm{~h}$ to $2625 \mathrm{~K}$ with a $3.5-h$ hold at temperature. The hold at $2625 \mathrm{~K}$ was to allow complete solid- 
solution formation below the $\mathrm{UC}_{2}-\mathrm{C}$ eurectic melting temperature of $\sim 2725 \mathrm{k}$. The temperature was then increased to between 2775 and $2875 \mathrm{k}$ and was held for $2 \mathrm{~h}$.

\section{Development of substoichiometric $(\mathrm{J}, \mathrm{Zr}) \mathrm{C}$}

The carbide fuel elements should contain no free carbon and the carbon-to-metal ratio should range from 0.88 to 0.95 , to achieve the highest melting point, to minimize creep, to obtain usable strength properties at matrix temperatures $\overline{\$} 3000 \mathrm{~K}$, and to minimize uranium and carbon losses in flowing hot hydrogen gas.

Because of the several processing considerations described previously, the extruded carbide elements contained $\sim 3$ wto free carbon. Three alternative methods of removing the free carbon and rendering the resulting fuel-element matrix substoichiometric in carbon were explored. The simp? ?est process in principle was to leach out the excess carbon with hot hydrogen. After all the free carbon was removed, a portion of the chemically bound carbon could be removed by continuing the leaching process, viz.,

$$
\begin{aligned}
\mathrm{C}+\mathrm{H}_{2} \longrightarrow & \text { hydrocarbons } \\
(\mathrm{U}, \mathrm{Zr}) \mathrm{C}_{0.97} & +\mathrm{H}_{2} \longrightarrow(\mathrm{U}, \mathrm{ZI}) \mathrm{C}_{20.9} \\
& + \text { hydrocarbons. }
\end{aligned}
$$

A second inethod of obtaining substoichionetric $(U, 2 r) C$ was to subject the fuel elements containing the free carbon to a gas mixture similar to that used in the chemical vapor deposition of $\mathrm{ZrC}$ coatings. In effect, the free carbon in the fuel element reacted to form $\mathrm{ZrC}$ and then, under suitable conditions, the reaction would continie after the free carbon was exhausted, with zirconium being added to the $(\mathrm{U}, \mathrm{Zr}) \mathrm{C}$ to proiuce a fuel substolchiometric in carbon. The overall reactions can be represented as follows:

$$
\begin{aligned}
(\mathrm{U}, \mathrm{Zr}) \mathrm{C} & +\mathrm{C}_{\text {free }} \frac{\mathrm{ZrCl} 4}{\mathrm{H}_{2}, \mathrm{HCl}, \mathrm{A}}(\mathrm{U}, \mathrm{Zr}) \mathrm{C}_{20.9} \\
& + \text { some hydrocarbons. }
\end{aligned}
$$

A third method, a combination of the first two, was the most practical. The free carbon was removed by flowing hydrogen at a temperature of 2200 to $2300 \mathrm{~K}$ for 40 to $60 \mathrm{~h}$. The elements were then impregnated with zirconium in a gas mixture of the following composition (vols): $\mathrm{ZrCl}_{4}, 1.8 \% ; \mathrm{H}_{2}, 8.28$; $\mathrm{CH}_{2}, 0.028$; $\mathrm{HCl}, 0.108$; and $\mathrm{Ar}, 89.98$. The temperature of impregnation was $~ 1900 \mathrm{~K}$.

The elements were given a final heat treatment at $\sim 2800 \mathrm{~K}$ for $2 \mathrm{~h}$. The properties of elements made by this process are described in Table VI of the main body of the report.

\section{ACKNOWLEDGMENTS}

The following people should be given credit for the development of the $(U, \mathrm{z} x) \mathrm{C}$ all-carbide fuel element: F. Criss, K. Davidson, A. Driesner, D. MacMillan, D. Schell and T. Wallace. 